Международная Научно-Исследовательская Федерация «Общественная наука»

\title{
НАУКА РОССИИ: ЦЕЛИ И ЗАДАЧИ
}

\author{
Сборник научных трудов \\ по материалам \\ V международной научной конференции
}

10 октября 2017 г.

\section{IJOURNAL_RU}

Екатеринбург 2017 
УДК 001.1

ББК 60

Наука России: Цели и задачи. Сборник научных трудов, по материалам V международной научно-практической конференции 10 октября 2017 г. Изд. НИЦ «Л-Журнал», 2017. - 76с.

\section{SPLN 001-000001-0190-SR \\ DOI 10.18411/sr-10-10-2017 \\ IDSP 000001:sr-10-10-2017}

В сборнике научных трудов собраны материалы из различных областей научных знаний. В данном издании приведены все материалы, которые были присланы на V международную научно-практическую конференцию Наука России: Цели и задачи

Сборник предназначен для научных работников, преподавателей, аспирантов и студентов.

Все материалы, размещенные в сборнике, опубликованы в авторском варианте. Редакция не вносила коррективы в научные статьи. Ответственность за информацию, размещенную в материалах на всеобщее обозрение, несут их авторы.

Информация об опубликованных статьях будет передана в систему Российского индекса научного цитирования (РИНЦ)

Электронная версия сборника доступна на сайте научноиздательского центра «Л-Журнал». Сайт центра: science-russia.ru

УДК 001.1

ББК 60 


\section{Содержание}

РАЗДЕЛ І. ФИЗИКА

Ловчиков В.И. «Обобщённая формула энергии». 6

Нэй Лин Метод согласования использующие wikipedia как онтология .... 10

РАЗДЕЛ ІІІ. ТЕХНИЧЕСКИЕ НАУКИ

Зеньков С.А., Минеев Д.А. Анализ теорий адгезии влажных связных грунтов к различным твердым поверхностям

Князев Д.А. Скоростной контроль сварных рельсовых стыков железнодорожного пути Эхолокационным методом ультразвукового контроля рельсов 16

Худовец В.И., Кузнецов Е.Е., Кузнецова О.А. Гидравлически-прижимное разрыхляющее устройство в ходовой системе полурамного трактора 21

РАЗДЕЛ IV. МЕДИЦИНА 25

Ольшанская Т.А., Воробьева М.В. Проблема фиксации съемных протезов при полном отсутствии зубов 25

Стёпкин Ю.И., Мамчик Н.П., Габбасова Н.В., Каменева О.В. Биологический фактор риска у медицинских работников 29

РАЗДЕЛ V. ВЕТЕРИНАРИЯ

Шульга Н.Н., Шульга И.С., Плавшак Л.П. Мониторинг лейкоза крупного рогатого скота в Амурской области 31 
РАЗДЕЛ VI. ПЕДАГОГИКА 35

Гончарова А.В., Казарова Т.А. К вопросу о функционировании идиом в англоязычной литературе 35

Кохичко А.Н. Ценность как базовая категория аксиологического подхода к содержанию начального обучения русскому (родному) языку 38

Тарасенко Н.Г. Методологические основы формирования онтологической составляющей глобально-ориентированного мировоззрения личности в современном образовательном процессе.

РАЗДЕЛ VII. ЭКОНОМИКА 50

Васильев Ю.Н., Ходус Н.А. Характеристики нормативно-правовой базы в сфере государственных и муниципальных закупок как фактора макросреды организации..... 50

Лайпанова 3.М., Боташева А.И. Внутренний контроль : понятие и основные элементы 53

Лайпанова 3.М., Лайпанова Н.У. Себестоимость. Понятие, виды и элементы. 55

Пучкунова Е.С., Ясменко Г.Н. Сложности в определении понятия «достоверность» применительно К бухгалтерской (финансовой) отчетности 57

РАЗДЕЛ VIII. МЕНЕДЖМЕНТ 60

Белевич Н.А., Ткачёва Г.А. Особенности мотивации и стимулирования труда работников здравоохранения 60

РАЗДЕЛ ІХ. ЮРИСПРУДЕНЦИЯ .64

Лятычевская Ю.В. Особенности правового регулирования референдума в Российской Федерации 64

Скопенко О.Р. Наследственный фонд: зарубежный опыт и перспектива развития в России ... 66 
РАЗДЕЛ Х. ФИЛОЛОГИЯ

Дрёмина С.Л., Семилетова А., Кошель Е.А. Особенности эпистолярного дискурса Ф.С. Фицджеральда (на материале писем к дочери) 71

Злобина И.С.,. Рублёва О.С Основные вопросы классификации неологизмов 


\section{РАЗДЕЛ І. ФИЗИКА}

\section{Ловчиков В.И. «Обобщённая формула энергии»}

Виброспеимаш

(Россия, Москва)

doi: 10.18411/sr-10-10-2017-01

idsp: 000001:sr-10-10-2017-01

\section{Аннотация}

Согласно закону сохранения энергии энергия ниоткуда не берётся, никуда не исчезает, а переходит из одной формы в другую. Детальный анализ дает возможность понять, что каждая из форм различных видов энергии должна быть связана с другой. В данной работе проведен анализ сходства различных видов энергии между собой. Сформулирована обобщенная формула энергии, которая связывает давление, напряжение и угловую скорость.

Ключевые слова: физика, энергия, обобщённая формула энергии, работа электрического тока, третий закон Кеплера, уравнение состояния идеального газа.

Введение. Согласно закону сохранения энергии энергия ниоткуда не берётся, никуда не исчезает, а переходит из одной формы в другую. Детальный анализ дает возможность понять, что каждая из форм различных видов энергии должна быть связана с другой [1-5].

Согласно второму началу термодинамики, существует необратимая последовательность преобразования энергии, в которой последней является тепловая энергия. Данный тезис вызывает некоторые вопросы. Например, каким образом образуются звёзды? Этот вопрос возникает, поскольку гравитация, которая ответственна за их сгущение, не является формой энергии. Все вышеперечисленные вопросы наводят на необходимость исследования форм энергии, включая поиск универсальной формы энергии, если таковая имеется.

Результаты и их обсуждение. Для того, чтобы провести некоторую аналогию между видами энергии, сначала был рассмотрен такой раздели физики, как Электричество $[1,2]$. Рассмотрим понятие работы электрического тока:

$$
\mathrm{A}=\mathrm{Uq}
$$

Поскольку левая часть формулы имеет размерность «Джоуль», то есть размерность энергии, то работа является произведением напряжения U на заряд q. Сделаем ряд преобразований с этой формулой. А именно: подставим вместо заряда q следующее выражение $\mathrm{q}=\mathrm{UC}$, где $\mathrm{C}$ - электрическая ёмкость. Вместо работы тока А поставим символ электрической энергии Е с индексом q (заряд) - Eq.

Тогда формула примет следующий вид:

$$
\mathrm{Eq}=\mathrm{U} 2 \mathrm{C}
$$

Таким образом, первая формула приняла более удобный вид для нашего дальнейшего рассмотрения.

Далее рассмотрим уравнение состояния идеального газа. Уравнение приведено ниже:

$$
\mathrm{PV}=\mu \mathrm{RT}
$$

где $\mathrm{P}$ - давление, $\mathrm{V}$ - объём, $\mu$ - количество моль газа, $\mathrm{R}$ - универсальная газовая постоянная, T - температура. 
Если перемножить правую часть уравнения и посмотреть на размерность получаемого результата, то получится размерность работы или энергии, а именно «Джоуль».

Правую часть уравнения можно условно назвать тепловой энергией, и в дальнейшем присвоить ей букву с индексом Qt, то есть энергия тепловая. Получается следующее:

$$
\mathrm{PV}=\mathrm{Qt}
$$

Далее рассмотрим третий закон Кеплера:

$$
\frac{T_{1}^{2}}{T_{2}^{2}}=\frac{a_{1}^{3}}{a_{2}^{3}}
$$

Квадраты периодов обращения двух планет, к примеру, солнечной системы, соотносятся так же, как кубы больших полуосей их орбит.

Если периоды обращения планет заменить на угловые скорости вращения, а большие полуоси на радиусы, то можно получить следующую формулу:

$$
\mathrm{w} 12 \mathrm{R} 13=\mathrm{w} 22 \mathrm{R} 23=\mathrm{C}
$$

где С - некоторая константа.

Тогда итоговая формула в общем виде приобретает вид:

$$
\mathrm{C}=\mathrm{w} 2 \mathrm{R} 3
$$

Теперь можно написать три рассмотренных выше уравнения рядом и оценить их схожесть. Однако для дальнейшего рассмотрения к данным известным уравнениям я предлагаю добавить некую вспомогательную формулу.

Данная формула имеет простой вид. Если представить себе некоторую абстрактную энергию Е, заключённую в некотором объёме V, то плотность этой энергии можно рассчитать в самом простом варианте по следующей формуле:

$$
\rho \mathrm{e}=\mathrm{E} / \mathrm{V}
$$

А энергия, соответственно, имеет следующий вид:

$$
\mathrm{E}=\rho \mathrm{eV}
$$
их анализ.

Далее запишем четыре рассмотренных выше уравнения (2), (3), (6), (8) и проведем

Конечный вид четырёх уравнений будет следующим:

$$
\begin{aligned}
\mathrm{Eq} & =\mathrm{U} 2 \mathrm{C} \\
\mathrm{Qt} & =\mathrm{P} V \\
\mathrm{C} & =\mathrm{w} 2 \mathrm{R} 3 \\
\mathrm{E} & =\rho \mathrm{e} \mathrm{V}
\end{aligned}
$$

В самый правый вертикальный столбец входят величины, которые довольно легко ассоциировать: радиус в третьей степени $\mathrm{R} 3$, объём $\mathrm{V}$ и ёмкость $\mathrm{C}$.

C точки зрения теоретической физики могут возникнуть сомнения относительно электрической ёмкости, поскольку в школьных учебниках по физике есть упрощённая оценочная формула электрической ёмкости, где она прямо пропорциональна площади пластин конденсатора и обратно пропорциональна расстоянию между ними:

$$
\mathrm{C} \sim \frac{S}{\mathrm{~d}}
$$

И все же предлагаю соотносить электрическую емкость с объемом. 
Продолжим. Первый столбец правых частей уравнений (U2, P, w2, ре) требует пояснения. Стоит сказать, что угловая скорость связана с линейной скоростью следующим уравнением: $\mathrm{v}=\mathrm{w} \cdot \mathrm{r}$. Иными словами, говоря о линейной скорости, мы также можем говорить и об угловой скорости.

Может возникнуть вопрос относительно соотнесения напряжения $U$ и угловой скорости w. Тут уместно рассмотреть формулу электродвижущей силы (ЭДС) генератора [2]:

$$
E=\frac{2 p}{60} \frac{N}{2 a} n \Phi
$$

В правой части уравнения есть величина $\mathrm{n}$, которая представляет собой угловую скорость вращения генератора. Таким образом, чем быстрее скорость вращения генератора, тем больше ЭДС на выходе. Стоит отметить, что эта зависимость линейная. Помимо этого размерность ЭДС будет такой же, как и у напряжения U.

Таким образом, в общем виде, используя символы $\mathrm{U}$ и w, мы можем записать:

$$
\mathrm{U}=\mathrm{f}(\mathrm{w})
$$

То есть, напряжение есть функция угловой скорости в первой степени.

Далее мы рассмотрим формулы, которые связывают между собой давление и скорость. В частности, так выглядит основное уравнение молякулярно-кинетической теории газов:

$$
\mathrm{p}=\frac{1}{3} \mathrm{~m} 0 \mathrm{nv} 2
$$

Здесь $\mathrm{p}$ - давление газа, a v - скорость частиц газа.

Скорость распространения звука в среде:

$$
\mathrm{a} 2=\frac{d p}{d \rho}
$$

где а - скорость звука в среде, $\mathrm{p}$ - давление среды, $\rho$ (ро) - плотность среды.

Подъемная сила определяется следующим выражением [2]:

$$
\mathrm{Y}=\mathrm{C} \rho \frac{v^{2}}{2} \mathrm{~S}
$$

где $\mathrm{Y}$ - подъёмная сила, C - коэффициент подъёмной силы, $\rho$ - плотность среды, v скорость аппарата, $\mathrm{S}$ - площадь крыла.

Если перенести площадь крыла в левую часть, то формула приобретёт вид:

$$
\mathrm{P}=\mathrm{C} \rho \frac{v^{2}}{2}
$$

В левой части уравнения находится давление на крыло.

Таким образом, из этих трех форму видно, что давление в разных формулах из разных областей физики связано с линейной скоростью через её квадрат. И, если подставить вместо неё угловую скорость, то получим следующий вид:

$$
\mathrm{P}=\mathrm{f}(\mathrm{w} 2)
$$

Таким образом, давление есть функция скорости во второй степени.

Вывод. Анализ формул (2), (3), (6), (8), представленных в работе показал, что существует определенная связь между квадратом угловой скорости w2, квадратом напряжения U2 и давлением P. Величину w2 вполне можно было бы назвать напором, по аналогии с величиной скоростного напора, применяемого в гидравлике [6].

Тогда средний столбец формул (2), (3), (6) и (8) звучит так: напряжение, давление, напор, плотность. Весьма не случайный ряд физических величин.

Почему я считаю приемлемым лингвистическое соотнесение понятий в естественнонаучной, как кажется, области знаний? 
Да потому, что, на мой взгляд, данное обобщение разных формул, а значит и форм энергии, является уже скорее философским или мировоззренческим. И, стало быть, вполне может осуществляться с использованием терминологии и понятий не только естественных наук.

\section{Обобщённая формула энергии}

Финальный вид обобщённой формулы энергии принимает следующий вид:

$$
\ni=w^{2} R^{3}
$$

То есть, любая энергия характеризуется, во-первых, параметром движения. И, вовторых, вовлечённым в это движение объёмом.

Глядя на эту формулу, вспоминается так же понятие «корпускулярно-волновой дуализм». И если составное понятие «корпускулярно-волновой» в свете выведенной формулы выглядит вполне допустимым, то вот «дуализм» вполне можно отбросить за ненадобностью.

Главный вопрос, который напрашивается при рассмотрении полученной формулы, как выглядит форма описанной ею энергии?

Анализ формулы уже дал весьма любопытные следствия, о которых я надеюсь рассказать в последующих статьях.

$$
* * *
$$

1. А.А. Детлаф, Б.М. Яворский, М.Б. Милковская. Курс физики. Том I. Механика. Основы молекулярной физики и термодинамики. - М.: ВЫСШАЯ ШКОЛА, 1973. - 384 с.

2. Лойцянский Л.Г. Механика жидкости и газа. Учебник для вузов. - М.: Дрофа, 2003. -840 c.

3. Киттель Ч. Введение в физику твердого тела. - М.: Наука, 1978. - 291 с.

4. Блейкмор Дж. Физика твердого тела. - М.: Мир, 1988. - 599 с.

5. Павлов В.П., Хохлов А.Ф. Физика твердого тела. - М.: Высшая школа, 1985. - 384 с.

6. Чугаев Р.Р. Гидравлика: Учебник для вузов - Л.: Энергоиздат, 1982. - 672 с. 


\title{
РАЗДЕЛ ІІ. ИНФОРМАЦИОННЫЕ ТЕХНОЛОГИИ
}

\author{
Нэй Лин \\ Метод согласования использующие wikipedia как онтология
}

Курский государственньй университет

(Россия, Курск)

doi: $10.18411 / \mathrm{sr}-10-10-2017-02$

idsp: 000001:sr-10-10-2017-02

\section{Аннотация}

В статье анализируется один из способов согласование документов и статей использующие Wikipedia как онтология. Определяются подходы к реализации этого способа. Согласование текста традиционными методами осуществляется на основе синтаксический информации, а не семантической информации. Поэтому система кластеризации не понимает значение слов, и при этом в документах имеются синонимы и полисемии. Но здесь существуют и другие проблемы, которые приводят к потере данных и ошибкам в информации. Когда осуществляется замена онтологией одинаковых семантически слов, возникает вероятность потери данных. В этой статье предлагается новый метод согласование, который использует Wikipedia понятия и Wikipedia категории

Ключевые слова: кластеризация, онтология, поиск, семантический вес

Понятие онтологии в информатике используется для представления доменов пространства. Например, в промышленном производстве, научных исследованиях, сельском хозяйстве, военной области и т.д. Посредством онтологии определяются понятия в информатике.

Общая онтология (высший уровень онтологии) представляет собой самую общую онтологию, прямо или косвенно связанную с другими онтологиями. Онтология строиться для конкретной предметной области. Например, спорт, медицина, промышленное производство. Задача онтологии представление, обработка и использование знаний предметной областей.

Онтология состоит из трех частей: понятия, свойства и отношения между понятиями. Все они используются для представления и обработки текстов. Использование онтологии для анализа документов заключается в выделении понятий онтологии, которые совпадает с актуальными термами документа. При этом исходные слова заменяются получающимися понятиями онтологии или добавляется как дополнителные характеристики. После этого отношения между атрибутами и понятиями онтологии используется для анализа документа.

B Wikipedia каждая статья имеет единственный заголовок. Таким образом, имеется сходство Wiki заголовка и понятия в онтологии. Эквивалентность этих понятий позволяет использовать их для перенаправленных ссылок. Это средство структуры Wiki представляет собой иерархическую систему категоризации. Чтобы сравнивать термины текстов и понятия онтологии, надо применять строгие методы согласования. При точном совпадении - метод прямого соответствия актуальных термов и понятий онтологии. Когда актуальные термы не существует, в понятиях онтологии используют связанные понятия в базе знаний, которые строятся на отношениях между wiki понятиями и документами. После завершения процесса поиска соответствий у каждого документа появляется набор wiki понятий. Поэтому в wiki поисковая система каждый документ связывает с определенной категорией документов.

Wikipedia состоит из множества документов, у которых есть собственные заголовки. Эти заголовки сходны понятиям онтологии. Равнозначные понятия онтологии формируют непрямые ссылки. Поэтому Wikipedia - это иерархическая система 
категоризации. Каждая статья связанна с одной категорий. Из-за этого структура онтологии становиться потенциальной онтологией.

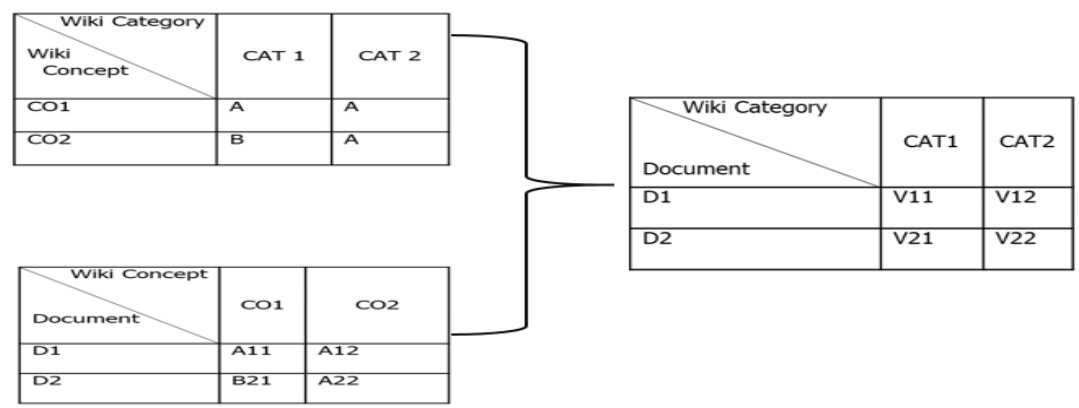

Рисунок(1)- Согласование документов и Wiki понятии

Метод согласования связанных понятий в базе знаний работает за два шагом. На первом шаге строится матрицы Wiki терм - понятия. Каждое слово представляется, как понятия вектор. Связывающие значение TF-IDF[5,4] между Wiki-понятиями и Wikiтермами статьи представляет значение этого вектора. Для того чтобы уменьшить время обработки необходимо убрать незначимые слова с помощью TF-IDF знания.

\begin{tabular}{|c|c|c|c|c|c|}
\hline \multirow{2}{*}{$\begin{array}{l}\text { Wiki Concept } \\
\text { Article }\end{array}$} & \multicolumn{5}{|l|}{ Wiki Concept Co } \\
\cline { 2 - 6 } & $C_{1}$ & $C_{2}$ & $C O_{3}$ & $\ldots \ldots$ & $C O_{N}$ \\
\hline$W_{1}$ & $W C_{11}$ & $W C_{12}$ & $W C_{13}$ & $\cdots \cdots$ & $W C_{1 N}$ \\
\hline$W_{2}$ & $W C_{21}$ & $W C_{22}$ & $W C_{23}$ & $\cdots \cdots$ & $W C_{2 N}$ \\
\hline$\ldots$ & & & & & \\
\hline$W_{N}$ & $W C_{N 1}$ & $W C_{N 2}$ & $W C_{N 3}$ & $\cdots \cdots \cdots$ & $W C_{N N}$ \\
\hline
\end{tabular}

Рисунок (2)- Матрица Wikicmaтьи и Wikinонятии

$$
r_{k}^{d_{j}}=\sum_{w_{i} \in d_{j}} t f i d f_{d_{j}}^{w_{i}} \bullet t f i d f_{c_{k}}^{w_{i}}
$$

Где- $d_{j}$ - документы в наборе документов

$C_{k}-$ понятии на Вики понятии

$W_{i}$ - каждое слово в $d_{j}$

На втором шаге надо создать матрицу терм - понятие или документ - понятие, чтобы определить отношения Wiki понятия и документа. При этом используют предыдущую формулу.

$* * *$

1. Hotho, A., Staab, S.andStumme, G. 2003. Wordnet improves text document clustering. In Proceedings of Semantic Web Workshop, the 26th annual International ACM SIGIR Conference. (Toronto, Canada, Jul. 28Aug.1, 2003)

2. Hotho, A., Maedche, A. and Staab, S. Text Clustering Based on Good Aggregations, In Proceedings of the 2001 IEEE International Conference on Data Mining. (San Jose, CA, Nov. 29-Dec.02, 2001,). IEEE Computer Society, Washington, DC, 07-608.

3. Yoo, I., Hu, X. and Song, I.-Y. 2006. Integration of semantic-based bipartite graph representation and mutual refinement strategy for biomedical literature clustering. In Proceedings of the 12th ACM SIGKDD international conference on Knowledge discovery and data mining. (Philadelphia, PA, August $20-23,2006$ ). ACM Press, New York, NY, $791-796$.

4. Zhang, X., Jing, L., Hu, X., et al. A Comparative Study of Ontology Based Term Similarity Measures on Document Clustering. In Proceedings of 12th International conference on Database Systems for Advanced Applications. (Bangkok, Thailand, April 9-12, 2007).115-126.

5. G. Salton, "The SMART Retrieval System Experiments in Automatic Document Retrieval", New Jersey, Englewood Cliffs: Prentice Hall Inc., 1971.

6. G. Salton and C. Buckley, "Term-Weighting Approach in Automatic Text Retrieval," Information Processing \& management, vol. 24,no. 5, 1988, pp. 513-523. 


\title{
РАЗДЕЛ ІІІ. ТЕХНИЧЕСКИЕ НАУКИ
}

\author{
Зеньков С.А., Минеев Д.А. \\ Анализ теорий адгезии влажных связных грунтов к различным твердым \\ поверхностям
}

Братский государственный университет (Россия, Братск)

doi: 10.18411/sr-10-10-2017-03

idsp: 000001:sr-10-10-2017-03

\section{Аннотация}

Проведен анализ известных теорий адгезии влажных связных грунтов к различным твердым поверхностям. Выявлены определенные противоречия, объясняющие причины адгезии и ее зависимость от следующих факторов: шероховатости твердой поверхности, химического состава и величины гидрофобности материала рабочих органов машин, давления и времени прижатия, вида грунта, влажности и температуры в зоне контакта. Сделан вывод, что требуется проведение дополнительных экспериментов с целью устранения выявленных противоречий.

Ключевые слова: Адгезия, грунт, электромолекулярная теория, вакуумная теория, гидрофобность, шероховатость, производительность, эксперимент.

Введение. Разработка влажных грунтов связана с намерзанием и налипанием грунта на рабочие органы землеройных машин, что существенно снижает их производительность [1-35]. Перевозка глинистых минералов и горных пород, их содержащих, транспортом также влечет их прилипание и примерзание к металлическим поверхностям кузовов транспортных средств, что создает трудности при разгрузке.

Для решения проблемы предотвращения прилипания и примерзания глинистых минералов к рабочим органам землеройных машин и к поверхностям кузовов транспортных средств необходимо знание явлений, происходящих при соприкосновении рабочей поверхности и грунта.

Различные организации занимаются разработкой способов и устройств для борьбы с налипанием, однако как показывает практика ни одно из них не работает эффективно, что говорит о недостаточной изученности вопроса и отсутствии надежной модели исследования процесса прилипания глиносодержащих веществ к поверхности твердых материалов [12].

Постановка задачи. Проанализировать существующие теории адгезии влажных связных грунтов с твердыми поверхностями скольжения.

Решения задачи. Под адгезией (прилипанием) понимают явление возникновения поверхностных связей между контактирующими разнородными телами (фазами), препятствующих взаимному разъединению этих тел [13-14].

Многие исследователи, ссылаясь на электрическую теорию Дерягина - Кротовой, отмечают, что липкость - результат действия электромолекулярных сил в зоне контакта грунта с другими материалами [15].

Согласно Заднепровскому Р.П. [14] адгезия является отражением комплекса физических свойств системы грунт-вода-рабочая поверхность (фаз I-III-II) с учетом газовой фазы и определяется молекулярным и ионно-электростатическим взаимодействием фаз I-III и I-II.

Молекулярная теория прогнозирует уменьшение адгезии пород с гидрофобными материалами. В связи с этим одним из способов уменьшения адгезии считается применение покрытий контактирующей поверхности гидрофобными материалами. 
Однако результаты исследований [16] показывают, что такой гидрофобный материал, как фторопласт обладает большей адгезией с грунтом, чем сталь, обработанная по 7-ому классу чистоты поверхности. Молекулярная теория предсказывает увеличение адгезии пленок с ростом температуры, однако у связных веществ с увеличением температуры адгезия уменьшается. Имеются и другие наблюдения, объяснить которые данной теорией пока не представляется возможным.

Согласно молекулярной теории липкость наряду с влажностью, давлением прижатия, временем действия нагрузки и видом грунта зависит от химического состава материала, контактирующего с веществом [14].

Корнет Э.А. после проведения экспериментов пришел к противоположному выводу [12]. Анализ результатов исследований показывает, что адгезия не зависит от химической природы твердых материалов, поверхности которых выполнены одинаковой шероховатости. Не влияет на величину адгезии и гидрофобность твердого материала.

В работе [17] отмечено, что поверхность каолинита исследовали с помощью растрового электронного микроскопа РЭМ-220. Было выявлено, что данная поверхность представлена хаотически расположенными частицами, объединенными в агрегаты. Последние образуют множество выступов и полостей. Было высказано предположение, что указанные полости, стенки которых при нагружении твердым материалом испытывают упругую или упруго-пластичекую деформацию, ведут себя как эластичные присосы, т. е. в полостях образуется давление разряжения газообразной фазы, которое и обуславливает адгезионную связь.

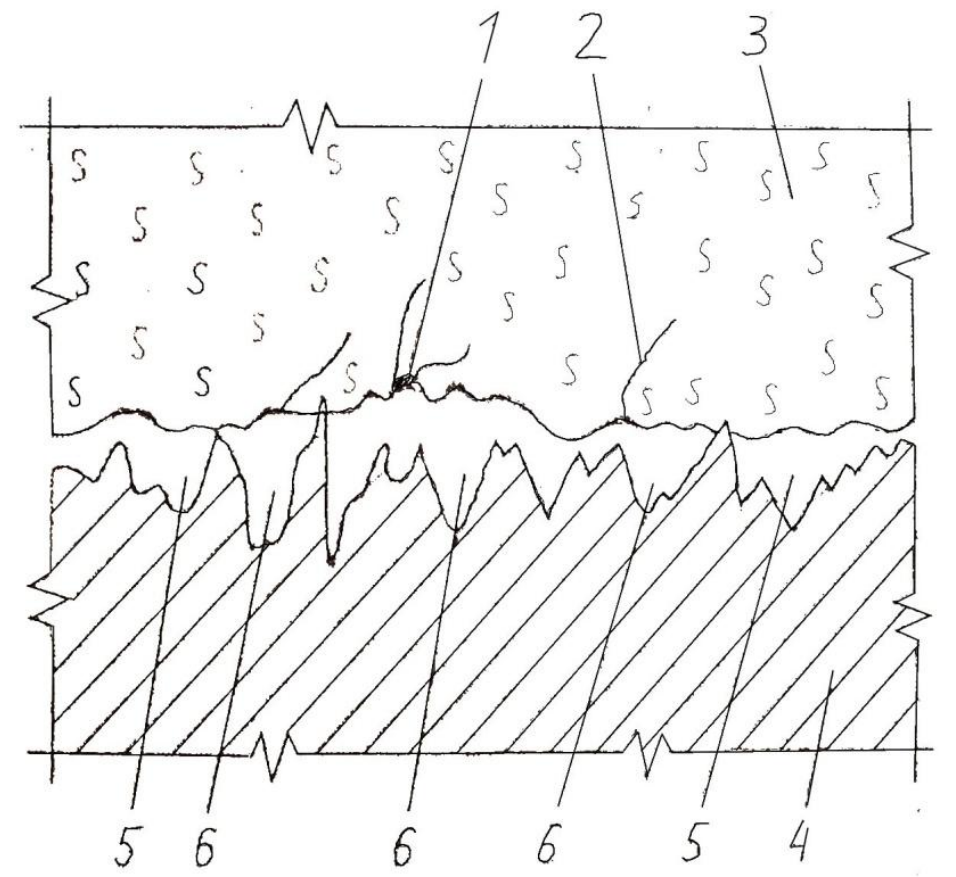

Рис.1. Схема взаимодействия связного грунта с твердой поверхностью.

При наложении образца связного грунта 3 (рис. 1) на шероховатую поверхность твердого материала 4 в местах их контакта образуются полости 5 и 6. Некоторые полости, например 5, сообщаются с атмосферой, а другие, например 6, изолированы. За время нагружения глины силой прижатия микровыступы на еe поверхности частично деформируются. Воздух, заключенный в объеме полостей 5 и 6 , в результате увеличившегося давления, частично выдавливается: из полостей 5 в атмосферу, а из полостей 6 по микротрещинам 1 вглубь глины, при этом выталкивается по микротрещинам 2 и жидкая фаза. Таким образом, при отрыве глины от поверхности твердого материала необходимо преодолеть давление разрежения воздуха в полостях 6, которое пропорционально силе отрыва. Микронеровности поверхности грунта работают как эластичные присосы. 
По утверждению Корнета Э.А. [17], предложенный им механизм взаимодействия связного грунта с твердым материалом позволяет объяснить целый ряд фактов, противоречащих существующей молекулярной теории адгезии. Например, снижение адгезии с увеличением шероховатости твердой поверхности происходит потому, что при увеличении класса чистоты высота микронеровностей поверхности твердого материала (среднее арифметическое отклонение профиля) уменьшается. Это приводит к уменьшению объема полостей, образованных неровностями поверхности пластичного вещества и твердой поверхности. При нагружении образцов в меньших объемах полостей создается более высокое давление воздуха, а при отрыве - более высокий вакуум. Последнее и приводит к увеличению адгезии с уменьшением шероховатости твердого материала. Уменьшение адгезии с увеличением угла наклона контактирующих тел происходит из-за снижения степени деформации стенок полостей пластичного вещества, что приводит к уменьшению вакуума в данных полостях. При увеличении температуры прилипших образцов растет объем воздуха в контактных полостях. Это снижает степень разрежения воздуха в полостях, что приводит к уменьшению адгезии образцов.

Выводы. Рассмотренные теории имеют различные объяснения природы адгезии связных грунтов с твердой поверхностью. Сторонники электромолекулярной теории утверждают, что адгезия обусловлена действием электромолекулярных сил в зоне контакта грунта с другими материалами. В то же время Корнет Э.А. утверждает, что под прилипанием следует понимать физический процесс, заключающийся во взаимодействии микрополостей поверхностей контактирующих тел, которое обусловлено действием вакуумных сил. Эти теории имеют свое теоретическое и экспериментальное подтверждение, следовательно, полученные различные выводы, возможно, говорят о недостаточной изученности такого явления природы, как адгезия влажных связных грунтов к твердым рабочим поверхностям.

$$
\text { *** }
$$

1. Абдразаков Ф.К. Одноковшовые экскаваторы могут работать производительнее // Механизация строительства. 1990. № 6. С. 16-17.

2. Зеньков С.А., Балахонов Н.А., Игнатьев К.А. Анализ возможного повышения производительности экскаваторов при устранении адгезии грунта к ковшу // Вестник МГСУ. 2014. № 2. С. 98-104.

3. Rajaram G., Erbach D.C. Effect of wetting and drying on soil physical properties. // Journal of Terramechanics 36 (1999) P. 39-49.

4. Зеньков С.А., Игнатьев К.А., Филонов А.С., Балахонов Н.А. Устранение налипания грунта на рабочие органы землеройных машин с использованием пьезокерамических излучателей // Модернизация и научные исследования в транспортном комплексе. 2013. Т. 1. С. 64-72.

5. Зеньков С.А., Диппель Р.А., Булаев К.В., Батуро А.А. Планирование эксперимента по исследованию влияния параметров теплового воздействия на сопротивление сдвигу грунта // Механики XXI веку. 2005. № 4. C. 52-56.

6. Зеньков С.А., Игнатьев К.А., Филонов А.С. Планирование эксперимента по применению пьезокерамических излучателей для борьбы с адгезией грунтов к рабочим органам землеройных машин // Механики XXI веку. 2012. № 11. С. 399-402.

7. Зеньков С.А., Курмашев Е.В., Красавин О.Ю. Анализ повышения производительности экскаваторов при использовании пьезокерамических трансдьюсеров // Системы. Методы. Технологии. 2009. № 4. С. 38-41.

8. Зеньков С.А., Курмашев Е.В. Анализ возможного повышения производительности экскаваторов при термоакустическом воздействии для устранения адгезии грунта к ковшу // Труды Братского государственного университета. Серия: Естественные и инженерные науки. 2008. № 2. С. 137-140.

9. Зеньков С.А., Батуро А.А., Булаев К.В. Теоретические предпосылки повышения производительности экскаваторов при устранении адгезии грунта к ковшу // Механики XXI веку. 2006. № 5. С. 79-81.

10. Зеньков С.А., Курмашев Е.В. Определение производительности экскаваторов при снижении адгезии грунтов // Вестник Иркутского регионального отделения Академии наук высшей школы РФ. 2010. № 2 (17). C. 191-195.

11. Зеньков С.А., Балахонов Н.А., Игнатьев К.А., Кожевников А.С. Неметаллические покрытия как профилактическое средство снижения адгезии на отвальных рабочих органах землеройных машин // Труды Братского государственного университета. Серия: Естественные и инженерные науки. 2013. Т. 2. C. 30-35. 
12. Корнет Э.А. Адгезионные свойства руд Кривбасса и их влияние на параметры вибротранспортных машин и технологию выпуска: автореферат дис. ... доктора техничеких наук: Институт проблем комплексного освоения недр. - Москва, 1988. - 31 с.

13. Дерягин Б.В., Кротова Н.А., Смилга В.П. Адгезия твердых тел.-М.: Наука, 1973.-279 с.

14. Заднепровский Р.П. Адгезионные свойства глинистых пород и снижение трения и прилипания при их разработке.: Автореф. дис. ... д-ра техн. наук.-Ленинград, 1085. - 38 с.

15. Зимон А.Д. Что такое адгезия. - М: Книжный дом «Либроком», 2013.- $176 \mathrm{c.}$

16. Ветров Ю.А., Кондра А.С. Результаты исследования липкости грунтов// Горные, строительные и дорожные машины. - Киев: Техника, 1972. - Вып. 14. - С. 12 - 17.

17. Корнет Э.А. Пути уменьшения прилипания пород к рабочим поверхностям горного и транспортного оборудования.// Горный журнал.1986. №12. С.50 - 52.

18. Зеньков С.А., Козик А.С., Буйлов О.А. Применение полимерных противоналипающих листов для снижения адгезии грунтов к рабочим органам землеройных машин // Механики XXI веку. 2010. № 9. C.112-114

19. Зеньков С.А., Батуро А.А., Булаев К.В., Диппель Р.А. Анализ структуры рабочего органа ковшового типа с устройством внешнего интенсифицирующего воздействия для снижения адгезии грунта // Механики XXI веку. 2005. № 4. С. 49-52.

20. Заднепровский Р.П. Рабочие органы землеройных и мелиоративных машин и оборудования для разработки грунтов и материалов повышенной влажности. - М.: Машиностроение, 1992. 176 с.

21. Зеньков С.А., Курмашев Е.В., Елохин А.В., Дэлэг Д. Перспективы применения гибких нагревательных ленточных элементов для снижения адгезии грунта к рабочим органам ковшового типа // Механики XXI веку. 2009. № 8. С. 164-167.

22. Зеньков С.А., Игнатьев К.А., Филонов А.С. Эффективность гибких нагревательных элементов для борьбы с адгезией грунтов к землеройным машинам // Труды Братского государственного университета. Серия: Естественные и инженерные науки. 2013. Т. 1. С. 134-137.

23. Зеньков С.А., Игнатьев К.А., Филонов А.С., Банщиков М.С. Исследование влияния теплового воздействия на адгезию грунтов к рабочим органам землеройных машин // Механики ХХІ веку. 2013. № 12. C. 228-232.

24. Зеньков С.А., Кожевников А.С., Кутимский Г.М. Использование электронагревательных гибких ленточных элементов для борьбы с намерзанием грунта к металлическим поверхностям рабочих органов землеройных машин // Механики XXI веку. 2014. № 13. С. 156-160.

25. Зенков С.А., Ереско С.П. Моделирование процесса копания грунта вибрирующим ковшовым рабочим органом при отрицательной температуре // Горное оборудование и электромеханика. 2008. № 12. С. 4449.

26. Зеньков С.А., Батуро А.А. Комбинированное устройство снижения адгезии грунта к ковшу экскаватора // Механики XXI веку. 2007. № 6. С. 76-78.

27. Зеньков С.А., Козик А.С., Буйлов О.А. Снижение адгезии грунтов к рабочим органам землеройных машин при помощи высокочастотного воздействия // Труды Братского государственного университета. Серия: Естественные и инженерные науки. 2011. Т. 2. С. 88-92.

28. Зеньков С.А., Козик А.С., Буйлов О.А., Зеньков А.С. Устранение адгезии грунтов к рабочим органам землеройных машин при помощи ультразвукового воздействия // Механики XXI веку. 2011. № 10. С. 146-148.

29. Зеньков С.А., Игнатьев К.А., Филонов А.С. Планирование эксперимента по применению пьезокерамических излучателей для борьбы с адгезией грунтов к рабочим органам землеройных машин // Механики XXI веку. 2012. № 11. С. 399-402.

30. Зеньков С.А., Товмасян Э.С. Математическая модель для определения параметров оборудования высокочастотного действия при проектировании ковшей экскаваторов // Современные проблемы теории машин. 2014. № 2. С. 41-44.

31. Зеньков С.А., Курмашев Е.В., Мунц В.В. Стенд для исследования влияния комбинированного воздействия на адгезию грунтов к землеройным машинам // Механики XXI веку. 2007. № 6. С. 15-18.

32. Зеньков С.А., Батуро А.А., Булаев К.В. Теоретические предпосылки повышения производительности экскаваторов при устранении адгезии грунта к ковшу // Механики ХХІ веку. 2006. № 5. С. 79-81.

33. Зеньков С.А., Жидовкин В.В., Ничаев А.Н., Курмашев Е.В. Применение оборудования теплового воздействия для снижения адгезии грунтов // Механики ХХІ веку. 2010. № 9. С. 129-132.

34. Зеньков С.А., Булаев К.В., Батуро А.А. Планирование эксперимента для определения влияния жидкостного слоя на сопротивление сдвигу грунта по металлической поверхности при отрицательной температуре // Механики XXI веку. 2006. № 5. С. 84-87.

35. Зеньков С.А., Балахонов Н.А., Игнатьев К.А., Кожевников А.С. Неметаллические покрытия как профилактическое средство снижения адгезии на отвальных рабочих органах землеройных машин // Труды Братского государственного университета. Серия: Естественные и инженерные науки. 2013. Т. 2. C. $30-35$. 


\section{Князев Д.А. \\ Скоростной контроль сварных рельсовых стыков железнодорожного пути Эхолокационным методом ультразвукового контроля рельсов}

ГУП «Московский метрополитен» (Россия, Москва)

doi: $10.18411 / s r-10-10-2017-04$

idsp: 000001:sr-10-10-2017-04

\section{Аннотация}

Рассмотрены проблемы, возникающие при выявлении дефектов в рельсе при скоростном и ручном ультразвуковом контроле, железнодорожного транспорта как в РФ. Проведён анализ пропуска дефектных мест в рельсе на основе официальных данных РЖД. Предложены совокупность практических приёмов для устранения выявленных причин и система действий, применяемая при ультразвуковом контроле.

Уделено внимание рассмотрению теоретических вопросов, а именно распространению ультразвуковых колебаний в упругой среде.

Рассмотрено практическое применение предлагаемого метода в промышленных масштабах, исследованного в режиме лабораторных эксплуатационных испытаний.

На основе анализа применения предлагаемого метода показана его эффективность, с аналогичными методами ультразвукового контроля.

Ключевые слова: рельс, метод, сварной рельсовый стык, ультразвуковые колебания, эхо-сигнал, пьезоэлектрический преобразователь, Эхолокационный метод ультразвукового контроля, вертикальный, вертикально ориентированный горизонтальный и горизонтально ориентированный отражатель, угол ввода, угол приёма, совмещённый, раздельно-совмещённый, раздельный режим работы, Зеркальноэхотеневой способ, эффективность и достоверность контроля.

Рельс, являясь контактным элементом с колесом подвижного состава и элементов верхнего строения железнодорожного пути, подвергается постоянному механическому, химическому, динамическому и иному воздействию. Вследствие динамического воздействия колёс подвижного состава на железнодорожные рельсы, отступления от технологии производства рельсов, нарушения требований инструкций по текущему содержанию пути, нарушений технологии сварки рельсов, коррозии рельса и других причин, рельс по всему сечению испытывает максимальные нагрузки и в связи с этим в нём по всему сечению возникают большое количество разнообразных дефектов.

Поскольку в зоне сварки металл меняет свою структуру с уменьшением пластичности, хрупкой прочности и твёрдости, зона сварного стыка является локализованной неоднородностью, то есть концентратором напряжений. Поэтому заключительной операцией производства сварных рельсовых стыков является - их дефектоскопия [1].

Методы неразрушающего контроля, применяемые в схемах прозвучивания для сплошного ультразвукового контроля рельсов, например

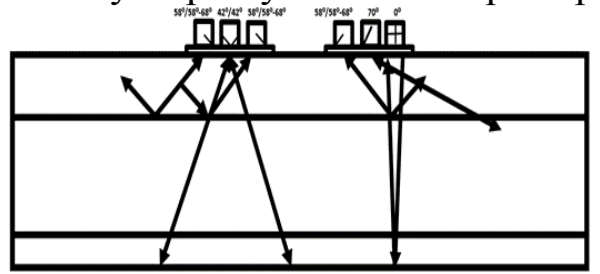

Схема прозвучивания применяемая на дефектоскопе УДС2-114 Авикон-11 ОАО «Радиоавионика»

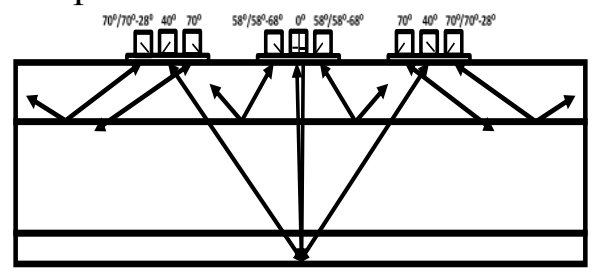

Схема прозвучивания применяемая на дефектоскопе «ФИРМА «ТВЕМА» 
в полной мере не обеспечивают требуемой эффективности контроля.

Так, от общего числа допущенных изломов с 2009 по 2015 годы, в среднем 32.3\% составляют изломы в зоне сварного рельсового стыка. Из них вертикальные и вертикально ориентированные дефекты составляют - $79.8 \%$ от общего количества допущенных изломов, а горизонтальные и горизонтально ориентированные $20.2 \%$.

По всему сечению, рельс, проверяется только на предприятиях, изготавливающих рельсы - приёмочный контроль, на рельсосварочных предприятиях и операторами дистанции пути рельс проверяется локально, только в зоне сварного рельсового стыка съёмными и ручными средствами НК [1]. При эксплуатационном контроле, мобильными и съемными средствами НК проверяется только головка, шейка и её проекция в подошве рельса

С целью регистрации разноориентированных отражателей по всему сечению рельса был применен Эхолокационный метод УЗК (Патент 2442152, Рисунок 2).

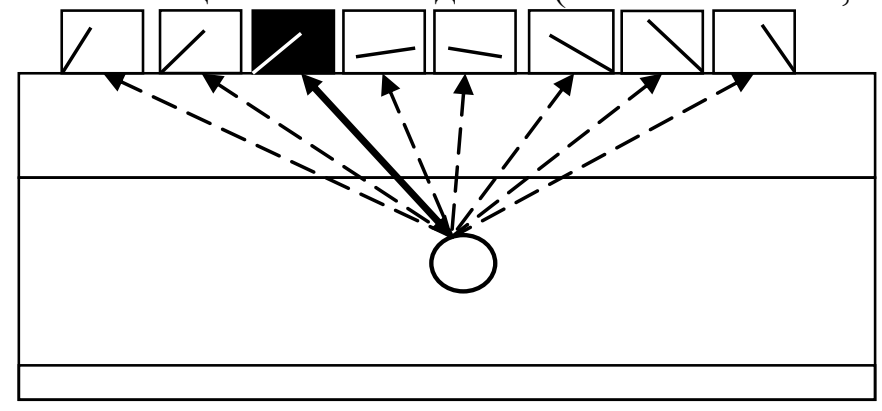

Эхолокаџионный метод ультразвукового контроля изделия по всему сечению применительно к рельсовой дефектоскопии (часть траектории распространения УЗК) [10]

Рисунок 2

Метод основывается на явлении рассеивания УЗК в однородной среде.

Принцип заключается в излучении в контролируемое изделие коротких зондирующих импульсов, возбуждающих в нём УЗК пьезоэлектрическим преобразователем, работающим в совмещённом или в раздельном режиме излученияприёма УЗК. Регистрация эхо-сигналов основывается, на приёме с поверхности сканирования множеством ПЭП, работающих в раздельном режиме работы в режиме приёма ЭС возбуждённых различными видами акустических волн на границе раздела сред.

При наклонном падении акустической волны происходят процессы отражения, преломления, трансформации (Рисунок 3). Каждая волна, возмущая среду, описывает поля распространения и рассеивания в широком интервале углов, то есть создаёт объёмное звуковое поле. Это звуковое поле состоит из множества звуковых полей. Основу звукового поля составляют геометрические поля, состоящие из траекторий описанных законами геометрической оптики, которые связываются между собой дифракционными полями, не допуская разрывов в звуковом поле.

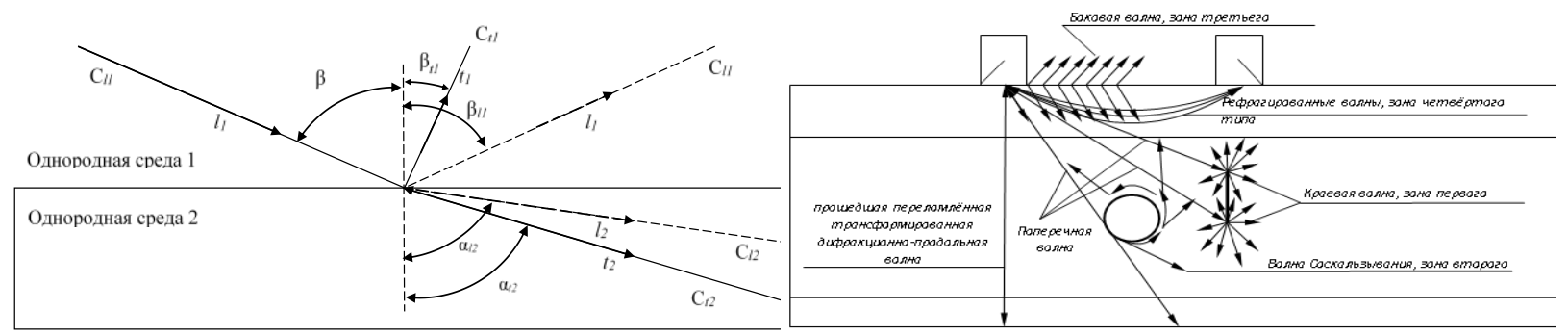

Схема образования продольной «l» и поперечной «t» волны на гранииу раздела двух сред по закону Снеллиуса [11]

Дифракиионные зоны первого, второго, третьего, четвёртого типа, возбуждаемые при наклонном вводе ультразвуковых колебаний [3] 
Волны дифракции, распространяясь в разных направлениях, проникают в озвучиваемую область и интерферируют в ней с отражёнными и преломлёнными волнами описываемыми законами геометрической оптики, образуя суммарное поле в объекте контроля [3] позволяя реализовать различные способы Эхолокационного метода УЗК (ЭЛМ УЗК).

Так как дефекты разноориентированы, озвучивание необходимо производить, чтобы акустические поля, создаваемые ПЭП излучающими и принимающими УЗК, пересекались друг с другом, создавая тем самым звуковой коридор для сканирования всего сечения.

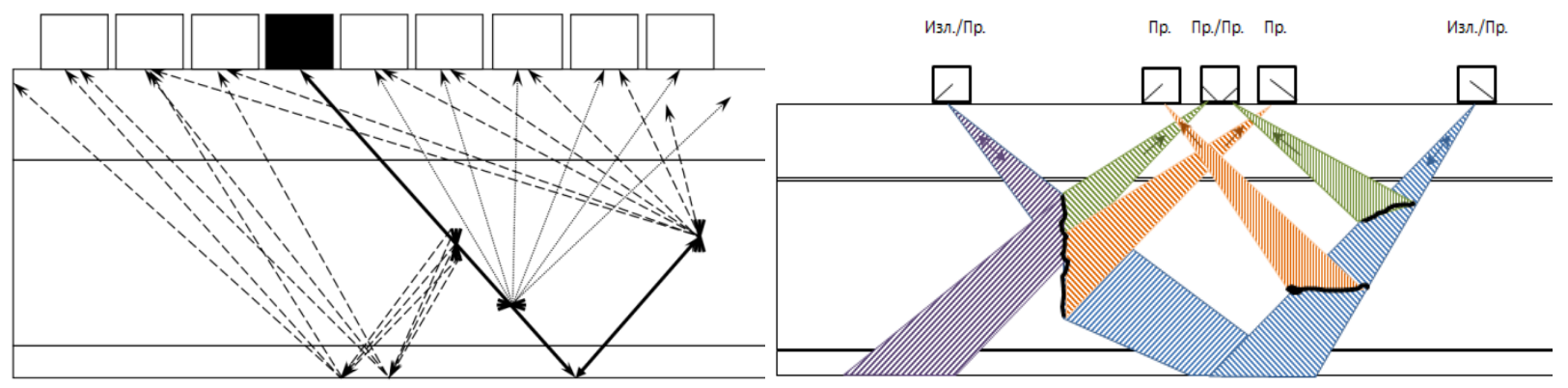

Зеркальноэхотеневой способа реализации Эхолокационного метода ультразвукового контроля изделия по всему сечению применительно к рельсовой дефектоскопии (часть траектории распространения У3K)

Рисунок 4

Способ реализации ЭЛМ УЗК, заключатся в регистрации ЭС возбуждённых поперечной волной «t2» отражённой от вертикальных, вертикально ориентированных, горизонтальных и горизонтально ориентированных отражателей, расположенных в проекции плоскости распространения УЗК, множеством наклонных ПЭП, работающих в раздельном режиме работы в режиме приёма, акустические оси диаграмм направленности которых лежат в одной вертикальной плоскости с излучающим ПЭП и в зависимости от положения отражателя направленных либо в одном направлении с акустической осью ПЭП-излучателя либо в противоположном направлении, размещённых на расстоянии Bп1=2htgkt2 [4] для регистрации однократно отражённых ЭС от горизонтальных и горизонтально ориентированных отражателей, ВП2=(2Htgat2)-(2htgkt2) [5] для регистрации двукратно отражённые ЭС от вертикальных и вертикально ориентированных отражателей, Bп3=(2Htgat2)+((2Htgat2)-(2htgkt2)) [5] для регистрации трёхкратно отражённых ЭС от горизонтальных, горизонтально ориентированных отражателей, между излучающим ПЭП и принимающими ПЭП.

Интегрируя возможность ПЭП одновременно регистрировать однократно и двукратно отражённые ЭС от горизонтальных, горизонтально ориентированных, вертикальных и вертикально ориентированных отражателей, в схемах прозвучивания при сплошном контроле мобильными, съемными и ручными средствами НК, ЭЛМ УЗК возможно реализовать различными вариантами компоновки.

Для проведения испытаний использовались дефектоскоп «ЭХО-КОМПЛЕКС» с ПО «КРУЗ-М ХР» и дефектоскоп «ЭХО-КОМПЛЕКС-2» с ПО «КРУЗ-2» и искательная лыжа с тремя искательными блоками по три ПЭП. С учётом количества каналов (6 или 9 каналов на одну нитку) и конструкционных размеров между ПЭП в искательной лыже была составлена «V-образная» схема прозвучивания (Рисунок № 5) реализующая Зеркальноэхотеневой способ реализации Эхолокационного метода УЗК (ЗЭТС ЭЛМ УЗК).

Проведены лабораторные испытания в режиме ручного и сплошного контроля съёмным средством НК, эксплуатационные испытания в режиме сплошного контроля мобильными средствами. Расчёт углов «at2» «kt2» произведён по формуле Bп2=(2Htgat2)-(2htgkt2), для регистрации отражателей на глубине (h) 45-75мм двукратно 
отражённым лучом угол приёма «kt2» составил $51^{\circ}$, для отражателей на глубине (h) 85 115 мм двукратно отражённым лучом угол kt2 составил $36^{\circ}$, для отражателей на глубине (h) $120-155$ мм двукратно отражённым лучом угол kt2 составил $32^{\circ}$, для регистрации донной поверхности однократно отражённым лучом использованы ПЭП с углом $\alpha \mathrm{t} 240^{\circ}$ (Bп1=2Htgat2). Но так как для рельсовой дефектоскопии производятся ПЭП с минимальным углом ввода $40^{\circ}$, они и были установлены с учётом углов раскрытия диаграмм направленностей. Все испытания проводились с обоими комплектами дефектоскопного оборудования для анализа применимости способа в зависимости от уровня техники.

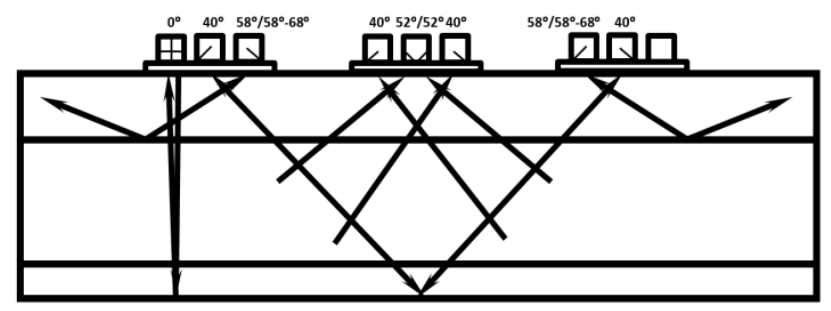

Рисунок 5

Испытания показали:

Испытания Зеркальноэхотеневого способа реализации Эхолокационного метода УЗК по регистрации моделей дефектов и натуральных дефектов, изъятых из железнодорожного пути

\begin{tabular}{|c|c|c|}
\hline Код дефекта & ЭМ УЗК & $\begin{array}{l}\text { ЗЭТ ЭЛМ } \\
\text { УЗК }\end{array}$ \\
\hline $\begin{array}{c}\text { модель дефекта 55, 56: поперечный пропил в виде сегмента в шейке } \\
\text { рельса, хорда A-32мм, глубина-6,5мм, h1-121мм, h2-153мм }\end{array}$ & - & + \\
\hline $\begin{array}{c}\text { модель дефекта 55, 56: поперечный пропил в виде сегмента в шейке } \\
\text { рельса, хорда A-28мм, глубина-5,5мм, h1-88мм, h2-116мм }\end{array}$ & - & + \\
\hline $\begin{array}{c}\text { модель дефекта 55, 56: поперечный пропил в виде сегмента в шейке } \\
\text { рельса, хорда А-32мм, глубина-6мм, h1-44мм, h2-76мм }\end{array}$ & - & + \\
\hline код дефекта 55: $\Delta \mathrm{X}-18 \mathrm{Mм}, \Delta \mathrm{L}-140 \mathrm{Mм}, \Delta \mathrm{h} 1-95 \mathrm{Mм}, \Delta \mathrm{h} 2-95 \mathrm{Mм}$ & + & + \\
\hline код дефекта 55: $\Delta \mathrm{X}-18 \mathrm{Mm}, \Delta \mathrm{L}-70 \mathrm{Mm}, \mathrm{h} 1-98 \mathrm{Mм}, \mathrm{h} 2-98 \mathrm{Mм}$ & + & + \\
\hline $\begin{array}{c}\text { модель дефекта 66, 69: сверление в подошве с центром на } \\
\text { продольной оси рельса, Ø 8мм, глубина-7мм }\end{array}$ & + & + \\
\hline $\begin{array}{c}\text { модель дефекта 52, 55, 56: горизонтальный пропил в шейке, L- } \\
\text { 40мм, глубина-8мм, h-100мм }\end{array}$ & + & + \\
\hline $\begin{array}{c}\text { модель дефекта 52, 55, 56: горизонтальный косой пропил в шейке } \\
\text { от торца, L-40мм, глубина-8мм, h-50мм }\end{array}$ & + & + \\
\hline $\begin{array}{c}\text { модель дефекта 66, 69: поперечный пропил в виде сегмента в } \\
\text { подошве с центром на продольной оси рельса, хорда А-30мм, h-7мм }\end{array}$ & + & + \\
\hline $\begin{array}{c}\text { модель дефекта 99: коническое отверстие в шейке рельса, } \\
\text { геометрические размеры: Ø-2мм с рабочей грани, Ø-5мм с } \\
\text { нерабочей грани, h-105мм }\end{array}$ & + & + \\
\hline Выявляемость дефектов в \% 10 шт. & $\mathbf{7 0 \%}$ & $100 \%$ \\
\hline
\end{tabular}

- Способ, обеспечивает регистрацию разноориентированных отражателей.

- Способ применим вне зависимости от уровня техники и пригоден к промышленному применению и универсален в использовании с различными видами неразрушающего контроля при сплошном и ручном контроле.

Достоинством ЗЭТС ЭЛМ УЗК является:

- Регистрация разноориентированных отражателей за счёт реализации раздельного режима работы ПЭП и облучения отражателей различными углами «ф» и «k» УЗК на основе построения звукового коридора диаграмм направленностей, что позволяет компактно и рационально разместить ПЭП на поверхности сканирования (Рисунок № 4, 5). 
- применение множества ПЭП с различными углами « $\beta$ позволяет осуществить приём дублированных ЭС, что позволяет снизить зависимость амплитуды ЭС от ориентации;

- односторонний доступ позволяет использовать его при ручном и сплошном контроле съёмными и мобильными средствами НК при V-120км\ч.

Недостатками ЗЭТС ЭЛМ УЗК является:

- зависимость стабильности акустического контакта между рабочей поверхностью искательного блока и поверхностью катания головки рельса. Однако, и этот недостаток имеет свой решения.

Одним из таких решений является метод магнитной памяти металла, позволяющий решить задачу стабильности акустического контакта и контроля «скрытой зоны» для ультразвуковых методов при скоростном контроле рельсов. Сущность метода заключается в оценке фактического напряжённо-деформированного состояния работающих конструкций, чего в настоящее время при неразрушающем контроле рельсов, уложенных в путь, не делается. Метод основан на регистрации и анализе распределения собственных магнитных полей рассеивания на поверхности изделия, возникающих в зонах концентрации напряжений, дефектов, неоднородности структуры металла и сварных соединений. В методе используются естественная намагниченность и последствие, которое проявляется в виде магнитной памяти металла -последствия в виде остаточной намагниченности металла, сформировавшейся в процессе изготовления и охлаждения в магнитном поле Земли, или в виде необратимого изменения намагниченности изделий в зонах концентрации напряжений и повреждений от рабочих нагрузок [7].

Метод обладает следующими достоинствами и преимуществами:

- не требует какой-либо подготовки объекта контроля,

- используется естественная намагниченность изделия,

- датчики имеют малые габаритные размеры и автономное питание,

- позволяет производить раннюю диагностику усталостных повреждений и «преддефектного» состояния всего сечения рельса по всей его длине в том числе и «скрытой зоны», а в сочетании с другими видам НК позволит кадифицировать историю развития дефектов,

- метод применим в течение всего календарного года;

- метод позволяет в режиме экспресс-контроля определять с точностью до 1мм зону концентрации напряжения, [7, 8].

Для повышения эффективности неразрушающего контроля рельсов при скоростном контроле мобильными средствами НК необходимо применение не только традиционных методов ультразвукового контроля, но и иных новых методов контроля.

Суммирующий эффект взаимодействия достоинств и преимуществ различных методов неразрушающего контроля рельсов, как применяемых в настоящее время, так и новых, характеризуется эффективностью, возрастающей в геометрической прогрессий, по сравнению с эффективностью каждого отдельного метода НК. Одними из таких новых методов и является Эхолокационного метода ультразвукового контроля изделия по всему сечению и Метод магнитной памяти металла способных дополнить систему контроля сварных рельсовых стыков в течение всего календарного года тем самым повысив его достоверность и эффективность. 
Реализация перечисленных выше достоинств повышает не только эффективность ультразвукового контроля рельсов, но и в целом системы обеспечивающей безопасность бесперебойных пассажирских и грузовых железнодорожных перевозок.

$* * *$

1. Конарев Н.С. Железнодорожный транспорт. Энциклопедия. - М: «Большая Российская энциклопедия». 1995. C.381

2. Кабардин О.Ф. Физика: Справ. материалы: Учеб. пособие для учащихся. - 3-е изд. - М.: Просвещение, 1991. C. 224-225.

3. Алёшин Н.П. Методы акустического контроля металлов. М.: Машиностроение, 1989. С.24-55.

4. Кретов Е.Ф. Ультразвуковая дефектоскопия в Энергомашиностроении. Учебное пособие - СПб.: «Радиоавионика», 1995. С. 159-161.

5. Погорелов А.В. Геометрия. Учебное пособие для 6-10 классов средней школы - М.: «Просвещение», 1985. C.82-83; 88-89.

6. НТД/ЦП-1-93 «Классификация дефектов рельсов», Министерство путей сообщения РФ Управление пути всероссийский научно-исследовательский институт железнодорожного транспорта, Издательство «Транспорт», Москва, 1993 год.

7. Дубов А.А., Дубов Ал.А., Колокольников С.М. Метод магнитной памяти металла и приборы контроля. Учебное пособие. Издание третье. - М: «Тиссо». 2006. С.3-24.

8. Дубов А.А. Метод магнитной памяти металла - диагностика XXI века. С.2-5.

9. ОАО РЖД Альбом изломов за 2009, 2010, 2011, 2012, 2013, 2014, 2015 г. (согласно п.2 дополнительных мероприятий по улучшению качества работы средств дефектоскопии в путевом хозяйстве железных дорог). Москва.

10. Патент 2442152 МПК G01N 29/04. Эхолокационный метод ультразвукового контроля по всему сечению/ Корепанов А.А., Князев Д.А. - Заявка №2010129458/28 от 16.07.2010. Опубликовано 10.02.2012. Бюл.№4.

11. Марков А.А. Шпагин Д.А., Ультразвуковая дефектоскопия рельсов. 2-е изд. Переработанное и дополненное - СПб.: «Образование - Культура». 2008. С. 39-42.

Худовец В.И., Кузнецов Е.Е., Кузнецова О.А.

Гидравлически-прижимное разрыхляющее устройство в ходовой системе полурамного трактора

ФГБОУ ВО Дальневосточный ГАУ

(Россия, Благовещенск)

doi: $10.18411 / \mathrm{sr}-10-10-2017-05$

idsp: 000001:sr-10-10-2017-05

\section{Аннотация}

Одним из способов снижения уплотнения почв по следу движения трактора является рациональное распределение массы трактора по его осям или дополнительное рыхление почв по следу движения колёсной системы.для решения проблемы предлагается способ снижения уплотнения почв колёсными движителями за счёт применения устройства, на которое получен патент на полезную модель.

Ключевые слова: плотность почвы, уплотнение почвы, колесные движители, трактор, дискаторный разуплотнитель следа полурамного трактора.

Изменение урожайности возделываемых культур зависит не только качества семенного материала, но и от сочетания природно-климатических и техногенных факторов, взаимодействующих в процессе растениеводства.

Несбалансированный отток поверхностных водс обрабатываемых агрофонов вследствие неудовлетворительного состояния мелиоративных систем, естественное природное переувлажнение в период проведения основных сельскохозяйственных работ, буксование движителей обрабатывающей колёсной техники и её многократный проход приводят к почвенному повреждению и формированию переуплотнённого поверхностного слоя, что в условиях зоны экстремального земледелия, к которой 
относится Амурская область, является причиной разрушения баланса плодородной и водно-воздушной структуры, развития эрозионных процессов и снижения урожайности возделываемых культур[3].При чём последствия разового интенсивного уплотнения сохраняются в виде почвенных напряжений гумусового горизонта в течение 2-5 лет.

Известно, что плотность почвы по следам движения колёсной сельскохозяйственной техники в пахотном слое составляет от 1,2-1,3 г/см3до 1,4-1,5 и 1,51,6 г/см3. Нормальной степенью уплотнённости являются параметры до 1,0-1,1 г/см3, к переуплотненным относятся почвы с плотностью: 1,3-1,5 г/см3(средняя степень уплотнения) и 1,5-1,6 г/см3и выше (сильная степень уплотнения). Основной причиной переуплотнения, как известно, является буксование колёсных движителей в ходе выполнения транспортных или сельскохозяйственных операций [4].

В последнее время в структуре агропромышленного комплекса России энергонасыщенные колёсные тракторы полурамной компоновки класса 5,0 и выше, отечественного и иностранного производства, в силу своих высоких тяговых характеристик, простоты и надёжности конструкции, универсальности агрегатирования со всевозможными орудиями и машинами, занимают лидирующую позицию в транспортном обеспечении технологии возделывания сельскохозяйственной продукции[2].

Однако эти тракторы имеют и свои конструктивные недостатки. В частности большая масса трактора (более 13,5 тонн), наличие высокого центра масс и нерациональное распределение эксплуатационной массы по осям накладывает ограничения на агротехнические скорости и вызывает значительный эффект почвенного уплотнения, а многократность прохода движителей при соблюдении параметров всех используемых технологий возделывания сельскохозяйственной продукции вызывает чрезмерную деформацию и переуплотнение плодородного слоя, что приводит к снижению пористости почв, ухудшению её водно-физических свойств, уменьшению влагообеспеченности корневой системы произрастающих сельскохозяйственных культур и ведёт к снижению урожайности на $15-30 \%$, а на глинистых и суглинистых почвах достигает и более высоких значений до 55\%.

Конструктивно-предусмотренное распределение массы по осям полурамного трактора, в частности «К-701» составляет: передняя ось-7700 кг, задняя ось-4300 кг. Соответственно степень уплотнения грунтов движителями передней оси этого трактора выше, чем задней оси. Следовательно, одним из способов снижения уплотнения почв по следу движения трактора является рациональное распределение массы трактора по его осям или дополнительное рыхление почв по следу движения колёсной системы[5].

Предлагается способ снижения уплотнения почв колёсными движителями за счёт применения устройства, на которое получен патент на полезную модель, принципиальная схема которого представлена на рисунках 1 а и 2 б - дискаторного разуплотнителя следа полурамного трактора[1], устанавливаемого на косыночных упорах с силовым шарниром в передней боковой части переднейполурамы трактора за движителями и состоящего из продольных реактивных штанг, фиксированных одним окончанием в силовом шарнире, а другим окончанием объединённых торсионной осью с разуплотняющими рабочими органами дискаторного типа, и прижимных силовых гидроцилиндров, установленных побортно в кронштейнах в тыльной части корпуса трактора, причём торсионная ось проходит через опорные вилки рабочих штоков прижимных гидроцилиндров.

Устройство работает следующим образом:

При въезде на поле, оператор трактора 6 при помощи прижимных силовых гидроцилиндров 13 опускает торсионную ось 11 предлагаемого устройства 1 в рабочее положение, заглубляя разуплотняющие рабочие органы дискаторного типа 12 в почву и прижимая на нужную глубину. В ходе движения трактора 6 рабочие органы- дискаторы производят работу по рыхлению, крошению и перемешиванию почвы по следу движения трактора, что уменьшает влияние ходовых систем колёсных полурамных тракторов на 
обрабатываемые агрофоны, снижает эффект переуплотнения почв, формирования плужной подошвы.

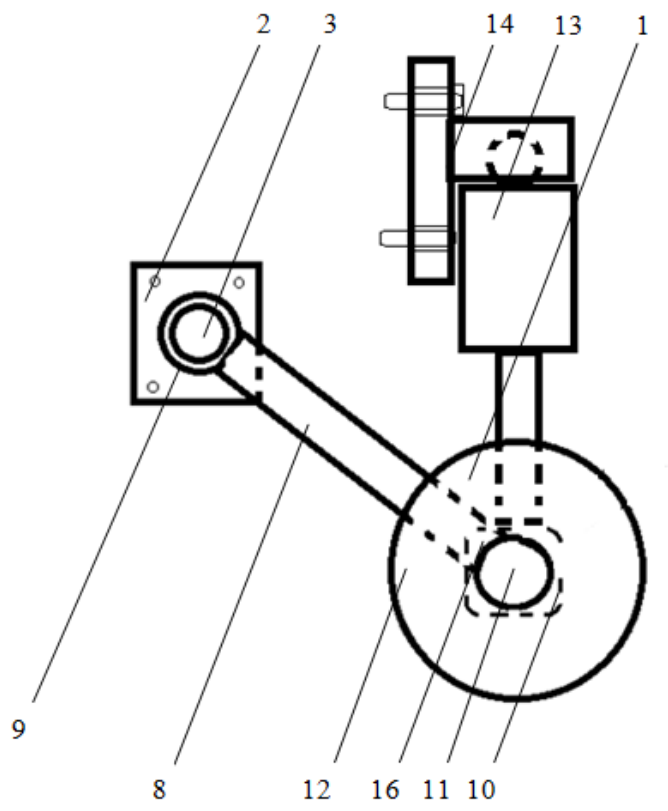

Рисунок 1а- Принципиальная схема дискаторного разуплотнителя следа полурамноготрактора:

1- общая конструкция устройства,2-косыночный упор,3- силовой шарнир,4- боковая часть рамьл трактора,5- передняя полурама трактора,6 - трактор полурамного типа, 7- движители, 8- продольнье реактивные штанги, 9- окончание реактивной штанги, 10- окончание реактивной штанги, 11- торсионная ось, 12- рабочие органы дискаторного типа, 13- силовой гидроиялиндр, 14-кронитейн, 15- тыльная часть корпуса трактора, 16- опорные вилки гидрочилиндров

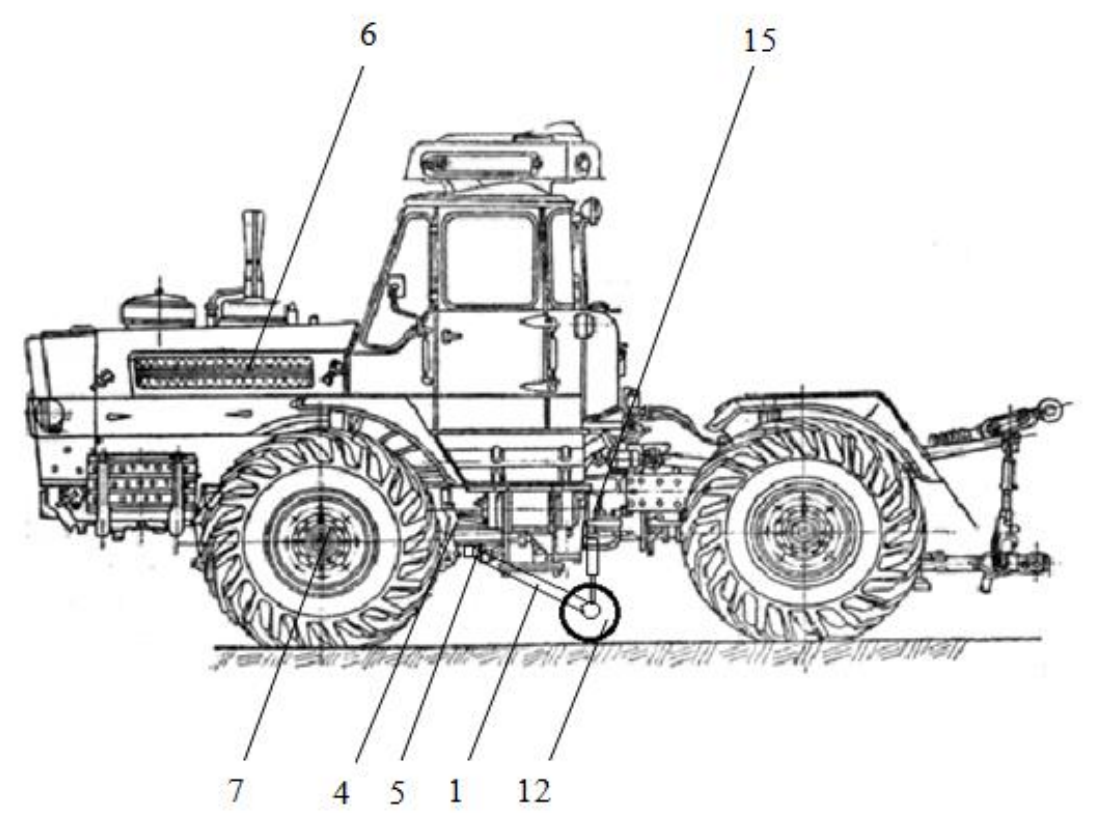

Рисунок 1б- Принщипиальная схема дискаторного разуплотнителя следа полурамноготрактора

При отсутствии необходимости движения с предлагаемым устройствомдискаторнымразуплотнителем следаполурамноготрактора, оператор трактора 6 прижимные силовые гидроцилиндры 13 не подключает и устройство 1 в рабочее положение не приводит.

Использование данной полезной модели, обладающей высокой надёжностью, низкой себестоимостью, материалоёмкостью и энергоёмкостью, удобством в обслуживании и эксплуатации, при достаточно несложной конструкции и простоте 
изготовления дискаторного разуплотнителя следаполурамноготрактора, уменьшит влияние ходовых систем колёсных тракторов на обрабатываемые почвы, снизит эффект переуплотнения, формирования плужной подошвы, поможет сбережению почвенного плодородия и пахотных ресурсов при проведении полевых работ, а также увеличит урожайность культур и эффективность применения полурамных тракторов в агропромышленном комплексе.

$$
* * *
$$

1. Дискаторный разуплотнитель следа полурамного трактора / Е.Е.Кузнецов и др./Патент на полезную модель № 171123, Заявка № 2016119453 от 19.05.2016, зарегистрировано ФИПС 30.03 .2016 г., опубл. 22.05.2017, Бюл. № 15

2. Кузнецов, Е.Е. Использование многоосных энергетических средств класса 1,4: монография/Е.Е.Кузнецов [и др.]//ДальГАУ- Благовещенск, 2013. -153 с.

3. Захарова Е.Б., Кашпура Б.И.,Немыкин А.А. Почвозащитные элементы технологии в растениеводстве // Дальневосточный аграрный вестн. -2008.-Вып.2.-С.25-30.

4. Ногтиков, А.А. Уплотнение почвы ходовыми системами машинно-тракторных агрегатов // Достижения науки и техники. - 2004. - №3. - С.34-36.

5. Щитов, С.В. Пути повышения агротехнической проходимости колёсных тракторов в технологии возделывания сельскохозяйственных культур Дальнего Востока: дис. докт. техн. наук: 05.20.01: защищена 20.05.09/Щитов Сергей Васильевич; ДальГАУ-Благовещенск,2009.-325 с. 


\title{
РАЗДЕЛ ІV. МЕДИЦИНА
}

\author{
Ольшанская Т.А., Воробьева М.В. \\ Проблема фиксации съемных протезов при полном отсутствии зубов \\ ФГБОУ ВО СГМУ им. В.И.Разумовского Минздрава России \\ (Россия, Саратов)
}

doi: $10.18411 / s r-10-10-2017-06$

idsp: 000001:sr-10-10-2017-06

\section{Аннотация}

В современной практике врача стоматолога протезирование пациентов с полным отсутствием зубов остается актуально сложным и трудоемким методом ортопедического лечения. При этом сложность для врача и зубного техника заключается не в технологических аспектах изготовления пластиночных протезов, а в решении проблемы их фиксации в полости рта. Анатомические условия для фиксации полных съемных пластиночных протезов у большинства пациентов неидеальны, что заставляет врача ортопеда-стоматолога при составлении плана лечения в каждом клиническом случае изучать возможности использования тех или иных методов и способов фиксации полных съемных пластиночных протезов. В данной статье проведен обзор методов фиксации полных съемных протезов, используемых в клинической практике врача стоматологаортопеда.

Ключевые слова: фиксация, съемные протезы, полное отсутствие зубов.

\section{Abstract}

In the modern practice of a dentist, prosthetics of patients with complete absence of teeth remains a very complicated and time-consuming method of orthopedic treatment. The complexity for the doctor and dental technician is not in the technological aspects of the manufacture of plate prostheses, but in solving the problem of fixing them in the oral cavity. The anatomical conditions for fixing complete removable plate prostheses in most patients are not ideal, which forces the orthopedic dentist doctor to make a plan of treatment in each clinical case to study the possibilities of using certain methods and methods of fixing complete removable plate prostheses. This article reviews the methods of fixing complete removable prostheses used in the clinical practice of a dentist-orthopedist.

Keywords: fixation,removable dentures,complete absence of teeth.

Изготовление съемных пластиночных протезов считается традиционным и наиболее распространенным методом лечения пациентов с полным отсутствием зубов. У данных конструкций есть свои преимущества и недостатки, но и современные врачистоматологи продолжают использовать при лечении пациентов с полным отсутствием зубов съемные пластиночные протезы.

Одной из главных задач врача, планирующего лечение такого пациента, является создание съемного протеза с надежной фиксацией, способного противостоять жевательным нагрузкам.

На фиксацию съемных пластиночных протезов влияют различные факторы: анатомические условия в полости рта и различные характеристики протезного ложа, возраст пациента, опыт применения съемных конструкций протезов ииндивидуальные особенности жевания и глотания у пациента.[1]

Фиксация съемного протеза набеззубой челюстипредотвращает смещение протеза в различных направлениях, оказывая при этом побочное механическое воздействие на ткани протезного ложа.Процесс фиксации съемных протезов основывается на 
анатомической ретенции, обусловленной естественными анатомическими образованиями, и явлениях адгезии поверхности базиса протеза и слизистой полости рта. Хорошо сохранившиеся альвеолярные гребни на верхней или нижней челюсти, выраженный свод нёба препятствуют горизонтальным смещениям протеза, ослабляющим силу его адгезии. Альвеолярные бугры на верхней челюсти ограничивают свободу движений протеза вперед во время разговора и приема пищи. Однако это не решает всей проблемы фиксации протеза, так как зачастую у пациентов анатомические условия в полости рта крайне неблагоприятны.[2]

По основному принципу действия выделяют физические, биофизические, механические и биомеханические методы фиксации полных съемных пластиночных протезов. Наиболее ранним методом фиксации является механический способ, который долгое время широко использовался. К нему относят лигатурное связывание протеза с челюстью; крепление пластиночных протезов пружинами и др. Механические методы первыми дали возможность восстановить функцию зубочелюстного аппарата на беззубых челюстях, однако из-за множества недостатков не нашли широкого применения. Постоянное давление на слизистую оболочку полости рта вызывало перенапряжение и быстрое утомление жевательных мышц, механическую травму слизистой оболочки, а так же нарушение гигиены полости рта. По этой причине от данного метода фиксации отказались до открытия методики имплантации челюстей, которая является одним из наиболее перспективных методов протезирования в современной ортопедической стоматологии.[3] Отдельное внимание стоит уделить методам фиксации с использованием магнитов, которые разные авторы относят к разным группам: механическим, физическим или биофизическим. Этот вид фиксации может осуществляться за счет отталкивающего или притягивающего действия магнитов. Отталкивающее действие оказывают внутрипротезные межчелюстные магниты, а притягивающее -внутрикорневые магнитные фиксаторы или одночелюстные магнитные имплантаты.[5] Внутрипротезные магниты укрепляются в базисах съемных протезов на верхней и нижней челюстях. При смыкании челюстей происходит контакт одноименных полюсов магнитов и их отталкивающая сила удерживает протезы от смещения с протезного ложа. Недостатком подобных конструкций является отсутствие отталкивающего действия при боковых движениях нижней челюсти при артикуляции или приеме пищи. Притягивающие магнитные имплантаты предусматривают хирургическое вмешательство для поднадкостничного или внутрикостного введения намагниченных имплантатов. Эта методика подразумевает наличие магнитов с противоположной полярностью в базисе съемного протеза и в поднадкостничном пространстве протезного ложа. Использование таких конструкций зачастую приводит к воспалительнодеструктивным изменениям тканей протезного ложа из-за постоянного сдавления мягких тканей под базисом протеза.[3] Внутрикорневые магнитные фиксаторы по механизму фиксирующего действия можно разделить на простые и сложные. Простые магнитные фиксаторы удерживают протез силой магнитного притяжения и изготавливаются лабораторным путем из специальных сплавов. Сложные магнитные фиксаторы изготавливаются промышленным способом и используют дополнительные механические крепления в виде рельсовых или кнопочных замков, телескопических коронок и т.д. [1]

Физические методы включают в себя адгезию, то есть слипание поверхностей двух разнородных тел и когезию сцепление молекул одного и того же вещества. Адгезия прямо пропорциональна площади соприкосновения поверхности протеза и протезного ложа, а так же толщины и вязкости слюны. Первое достигается точностью снятия оттиска и созданием микрорельефа базиса протеза в конгруэнтности со слизистой оболочкой. Второе зависит исключительно от индивидуальности организма пациента. Практически 
силы адгезии недостаточно для удержания протеза в покое или при сокращении жевательной и мимической мускулатуры, но с учетом присасывающей способности капиллярного слоя слюны данные показатели в разы повышаются. Для достижения более качественной когезии в настоящее время широко применяются различные гели, порошки, плёнки, способствующие улучшению фиксации протеза в полости рта. Биомеханические методы фиксации препятствуют смещению протеза в вертикальном направлении и включают использование анатомической ретенции, под надкостничной или внутрикостной имплантации, а также пластику альвеолярного гребня.[4]

Анатомическая ретенция при выраженных анатомических образованиях протезного ложа у пациента играет важную роль в удержании протеза на верхней или нижней челюстях, но врач всегда рассматривает возможность использования дополнительных способов фиксации.

Использование различных методов имплантации является современным и наиболее перспективным методом протезирования и позволяет избежать недостаточной ретенции протеза при полном отсутствии зубов. [3] Биофизический метод фиксации полных съемных пластиночных протезов основан на создании разреженного пространства под базисом протеза. Его применение планируется врачом с учетом анатомических особенностей границ протезного ложа, значительной податливости и небольшой подвижности тканей переходной складки во время функции. Это метод клапанной фиксации, предотвращающий смещение протезов от горизонтальных смещений и заключающийся в создании краевого замыкающего клапана по границе протезного ложа. За счет определенных анатомических условий в полости рта (выраженная податливость, куполообразный свод нёба, овальный или грибовидный альвеолярный отросток и многие другие), а так же отрицательного давления, созданного между слизистой оболочкой и базисом протеза, достигается максимальная фиксация и стабилизация протеза в состоянии покоя и в состоянии функциональной активности жевательных мышц. При этом формируются два вида клапанов: наружный и внутренний, благодаря которым в динамике формируется язычная и вестибулярная поверхности тела протеза и улучшается его устойчивость. Наружный клапан создается при прилегании подвижных тканей по краю протеза, а внутренний клапан формируется прилеганием к поверхности протеза неподвижных тканей (Маркскорс Р. 2005). Ретенция протезов у пациентов с полным отсутствием зубов улучшается при создании разряженное пространство по всей площади протезного ложа за счет использования анатомических особенностей слизистой оболочки протезного ложа и точного отображения рельефа слизистой оболочки на внутренней поверхности базиса полного съемного протеза. Тогда между двумя конгруэнтными поверхностями, разделенными тонким слоем слюны, возникают силы межмолекулярного сцепления, способствующие удержанию протеза. Благодаря своей эффективности и экономической доступности этот метод нашел наиболее широкое распространение в практике ортопедической стоматологии. Основными силами, способствующими эффективной фиксации полного съемного протеза на челюсти, являются силы функциональной присасываемости. Необходимо добиваться создания контакта между краем полного съемного протеза и слизистой оболочкой протезного ложа таким образом, чтобы обеспечить образование замыкающего клапана по всей границе протеза. Это позволит создать условия для фиксации его на челюсти, препятствования попаданию воздуха под протез в момент функции, удержания его за счет разницы давления воздуха, находящегося в пространстве между протезом и слизистой оболочкой протезного ложа (Гельман С. Е. исоавт.2002). Слизистая оболочка, прилегающая к краю протеза, должна перемещаться за ним при движениях, сохраняя при этом контакт с базисом полного съемного протеза. При смещении протеза со своего ложа слизистая оболочка переходной 
складки натягивается, но при этом она следует за границами протеза и замыкающий клапан не нарушается.[2]

На этапе оформления границ индивидуальной ложки и получения функционального оттиска необходимо определить и воспроизвести объем переходной складки по границе будущего протеза с учетом всех возможных функциональных движений для достижения наиболее эффективного контакта края протеза со слизистой оболочкой.[6]

Однако, анатомические условия на нижней челюсти в большинстве клинических ситуаций не позволяют создать замыкающий клапан и применяется данный метод преимущественно на верхней челюсти. Если у пациента недостаточно податливая слизистая оболочка протезного ложа, плоский свод нёба, недостаточно выраженный альвеолярный отросток или мелкое преддверие полости рта, то в этом случае будет весьма затруднительно добиться оптимальной фиксации протеза и на верхней челюсти.

Особое значение при ортопедическом лечении пациентов с полным отсутствием зубов имеет такие понятия, как: анатомическая ретенции, адгезия, функциональная присасываемость и мышечная стабилизации, которые мы рассмотрим подробнее. Точное соответствие рельефа слизистой оболочки протезного ложа и внутренней поверхности базиса протеза является главным условием для их получения. Не менее важным фактором для фиксации протезов является контакт слизистой оболочки щек, губ, языка с наружной поверхностью протеза. Горизонтальные силы, воздействующие на внешние поверхности протезов, не менее важны и должны учитываться при моделировании базиса полного съемного протеза. На полный съемный протез верхней челюсти в момент разжевывании пищи, как удерживающий фактор, действуют снаружи волокна щечной мышцы, а на внутренней стороне нижней челюсти язык, плотно прилегающий к базису при жевании и глотании (Rode M. 1986). При планировании съемного протеза на нижней челюсти необходимо учитывать состояние языка: при его гипертрофии или малоподвижности создаются углубления в базисе протеза в области жевательных зубов, а при хорошем напряжении его мышечных тканей и небольших размерах необходимо создавать отвесные края (MoritaT. 1993).

Выбор метода фиксации полного съемного протеза проводится врачом стоматологом-ортопедом и зубным техником с учетом индивидуальных клинических и анатомических особенностей пациента, правильность этого выбора способствует быстрой адаптации к конструкции и восстановлению ранее утраченных функций у пациентов с полным отсутствием зубов.

$$
* * *
$$

1. Наумович, С.А. Ортопедическая стоматология. Протезирование полными съемными пластиночными и бюгельными протезами С.А. Наумович.- Минск: БГМУ, 2009. 212 с.

2. Жолудев, С.Е. Адгезивные средства в ортопедической стоматологии С.Е. Жолудев. М.: Стоматология, 2007. 112 c.

3. Миш, К.Е. Ортопедическое лечение с опорой на дентальные имплантаты К.Е. Миш. М.: Рид Элсивер, 2010. $616 \mathrm{c}$.

4. Асташина Н. Б., Казаков С. В., Седегова О. А., Рогожников Г. И., Рогожников А. Г. Клиникотеоретическое обоснование применения постоянных магнитов для фиксации съемных зубных и зубочелюстных протезов Проблемы стоматологии.- 2011.- №4. С. 44-50.

5. Руководство по ортопедической стоматологии. Протезирование при полном отсутствии зубов под ред. И. Ю. Лебеденко, Э. С. Каливраджияна, Т.И. Ибрагимова, Е.А. Брагина. М.:ООО «Медицинская пресса», 2008. 372 c.

6. Кленкова М.И., Коннов В.В., Разаков Д.Х., Воробьева М.В., Масленников Д.Н.«Индивидуальная ложка для получения функционального оттиска с беззубой челюсти». // Патент на полезную модель № 145501 от 07.05.2014 г. 


\author{
Стёпкин Ю.И., ${ }^{1,2}$, Мамчик Н.П., ${ }^{1,2}$, Габбасова Н.В. ${ }^{2}$, Каменева О.В., \\ Биологический фактор риска у медицинских работников \\ ${ }^{1}$ ФБУЗ «Центр гигиены и эпидемиологии в Воронежской области» \\ ${ }^{2}$ ФГБОУ ВО «Воронежский государственный медицинский университет \\ им. Н.Н. Бурденко» \\ (Россия, Воронеж)
}

doi: $10.18411 / \mathrm{sr}-10-10-2017-07$

idsp: 000001:sr-10-10-2017-07

\title{
Аннотация
}

Онкологические заболевания являются одной из основных причин заболеваемости и смертности в мире. Факторами риска развития рака являются и некоторые инфекции, в том числе Helicobacterpylori, вирус папилломы человека (ВПЧ), вирус гепатита В, вирус гепатита С и вирус Эпштейна-Барра, которые были названы причиной примерно 15\% случаев рака, диагностированных в 2012 году по данным ВОЗ.

Ключевые слова. Биологический канцерогенный фактор, профессии риска, внутрибольничные инфекции, онкологические профессиональные заболевания.

Key words. Biological carcinogenic factor, risk professions, nosocomial infections, oncological occupational diseases.

\section{Цель работы:}

- Установить основные профессии с эпидемиологической канцерогенной настороженностью по биологическому фактору.

- Определить медицинские манипуляции, связанные с возможным риском распространения инфекционных и паразитарных заболеваний, пути и механизмы передачи возбудителей.

- Определить возрастную структуру лиц, подвергающихся воздействию биологических канцерогенных факторов.

- Дать оценку существующей системе профилактики.

\section{Результат}

Медицинский персонал лечебно-профилактических учреждений (ЛПУ) является группой профессионального риска по заболеваемости внутрибольничными инфекциями (ВБИ- ИСМП), вызываемыми патогенными и условно-патогенными микроорганизмами. Ведущим вредным фактором, оказывающим влияние на здоровье медицинского персонала, является биологический. Величина относительного риска формирования заболеваемости превышает единицу, что требует внедрение системы динамического наблюдения за состоянием здоровья, направленной на профилактику как общей, так и производственно-обусловленной заболеваемости.

Известные на сегодняшний день канцерогены делятся на три группы: физические, химические и биологические. К физическим факторам относятся солнечная и ионизирующая радиация, рентгеновское и электромагнитное излучение, воздействие высоких или низких температур и т.д. Группу химических канцерогенов образуют продукты переработки нефти, бензол, нитраты, галогены, алкоголь, смолы табачного дыма, консерванты, красители, краски, лаки, растворители, соли тяжелых металлов, продукты горения, некоторые лекарственные вещества. Группа биологических канщерогенов объединяет вирусы, бактерии, грибы, простейших, повышающих скорость образования опухолевых клеток и меняющих реакцию организма.

С помощью методов ретроспективного эпидемиологические исследования с использованием данных паспортов канцерогеноопасных производств с 2011 по 2015 год установлено, что в лечебно - профилактических учреждениях г. Воронежа присутствуют биологические канцерогенные факторы, такие как вирус Гепатита B, вирус гепатита $\mathrm{C}$, бактерия Helicobacter, Shistosomahaematobium, которые вызывают цирроз печени, рак желудка, рак мочевого пузыря. 
Канцерогенному риску подвержен персонал в возрасте от 18 до 49 лет.

Данный контингент занят в:

- отделениилабораторной диагностики;

- отделения эндоскопии;

- отделения хирургии;

- отделение гинекологии;

- в процедурном кабинете.

В отделении лабораторной диагностики заражение гепатитами В, С возможно при элементарных манипуляциях (взятие крови, инъекции), при более сложных (биопсия). Опасность заражения существует при трансфузиях крови и ее компонентов.

Эндоскопические методы обследования и лечения, несмотря на высокую информативность, эффективность, но и травматичность могут приводить к заражению хеликобактериозом, гепатитами $\mathrm{B}, \mathrm{C}$.

В отделении хирургии характерен гемотрансфузионный механизм передачи, где фактором передачи являются объекты, содержащие частицы крови в результате микротравм, порезов.

При выполнении гинекологических процедур возможны порезы гинекологическими инструментами во время операций, попадание крови на незащищённые слизистые(глаза, травмированная кожа).

В процедурном кабинете так же преобладает артифициальный механизм заражения при заборе крови, выполнении инъекций и других манипуляций.

Онкологические заболевания среди данного контингента не выявлены, но развитие опухоли начинается не сразу. С момента контакта организма с канцерогеном - фактором, запускающим активную трансформацию здоровых клеток в опухолевые, до появления клиники опухолевого заболевания проходит 10-15 лет.

\section{Выводы}

1. Современное развитие медицины, повышение технической оснащенности лечебных учреждений, современного оборудования, аппаратуры, инструментария, применение новых лекарственных средств и освоение новых методов диагностики и лечения ставят перед гигиенистами и эпидемиологами все новые задачи по профилактике неблагоприятных последствий для здоровья условий и характера трудовой деятельности врача.

2. При рациональной организации труда, исполнении гигиенических и эпидемиологических требований к условиям труда медицинских работников, выполняющих работы, связанные с риском возникновения инфекционных заболеваний можно сказать,что существующая система профилактики обладает достаточными рекомендациями и инструкциями по риску предотвращения заболеваемости медицинских работников. Используя их в должном объеме, значительно будет снижен риск инфицирования персонала, что способствует предупреждению риска воздействия биологических канцерогенных факторов. Необходимо дальнейшее наблюдение за группами риска, осуществление производственного лабораторного контроля с целью диагностирования возможных изменений в состоянии здоровья медицинских работников и обнаружения возбудителей в госпитальной среде.

$$
* * *
$$

1. Информационный бюллетень // Всемирная организация здравоохранения, февраль. 2012.

2. Попов В.И., Фаустов А.С., Каменев В.И. К вопросу о среде обитания и здоровом образе жизни // В сборнике: Актуальные проблемы восстановительной медицины, курортологии и физиотерапии. Материалы Международного конгресса «Здравница - 2008». 2008. С. 52-54.

3. Фаустов А.С., Попов В.И., Каменев В.И. Гигиена в графиках, рисунках, таблицах и схемах: Учебное пособие для студентов медицинских вузов / Воронеж, 2001. С. 136.

4. Попов В.И., Каменев В.И., Либина И.И., Мелихова Е.П. Гигиена детей и подростков: Учебное пособие для студентов педиатрического факультета / Воронеж, 2011. С.67. 


\title{
РАЗДЕЛ V. ВЕТЕРИНАРИЯ
}

\author{
Шульга Н.Н., Шульга И.С., Плавшак Л.П. \\ Мониторинг лейкоза крупного рогатого скота в Амурской области
}

Дальневосточный зональный научно-исследовательский ветеринарный институт (ФГБНУ ДальЗНИВИ)

(Россия, Благовещенск)

doi: 10.18411/sr-10-10-2017-08

idsp: 000001:sr-10-10-2017-08

\section{Аннотация}

Лейкоз крупного рогатого скота (Bovine leucosis) наносит серьезный финансовый ущерб скотоводству, делая невыгодным развитие отрасли, создает потенциальную опасность для человека через продукты питания и непосредственного ухода за больными животными. Источником bovine leucosis virus (ВЛКРС) являются больной скот. На территории Российской Федерации эпизоотическая ситуация по лейкозу в 2016 году изменилась в лучшую сторону, однако оставалась напряженной. Bovine leucosis согласно ветеринарной отчётности в 2016 году регистрировался в 68 территориях Российской Федерации. В итоге мониторинга лейкоза крупного рогатого скота в Амурской области с 2012 года растет количество исследованных в РИД животных, что указывает на усилении внимания ветеринарной службы области к проблеме лейкоза. Снижение числа реагирующих в РИД на лейкоз, связано с заменой животных РИД негативным скотом, а рост числа инфицированных ВЛКРС с перезаражением здорового скота. Большая часть (более 90\%) положительно реагирующих животных подвергается гематологическим исследованиям, хотя необходим $100 \%$ охват. В области снижается число неблагополучных по лейкозу населенных пунктов. Мониторинговые исследования показали, что в процессе проведения оздоровительных мероприятий ветеринарная служба области постоянно сталкивается с проблемой - нежелание владельцев скота заменять животных зараженных ВЛКРС - на здоровых по причине экономических потерь в результате убоя лейкозного скота. При составлении программы по ликвидации заболевания необходимо закладывать бюджетные средства на компенсацию потерь владельцам лейкозных животных. Также в основе постановки диагноза на медленную инфекцию должны лежать серологические методы исследования с использованием ИФА и ПЦР.

Ключевые слова: лейкоз, крупный рогатый скот, мониторинг, инфекция, эпизоотический процесс.

\section{Abstract}

Leukemia in cattle (Bovine leucosis) is causing serious financial damage to the cattle, making it unprofitable to industry, creates a potential hazard to humans through food and immediate care of sick animals. The source of bovine leucosis virus (BLV) are the sick cattle. On the territory of the Russian Federation epizootic situation on leukemia in 2016 has changed for the better, however, remained tense. Bovine leucosis in accordance with veterinary reporting in 2016 was recorded in 68 regions of the Russian Federation. In the end, monitoring of leukemia of cattle in the Amur region since 2012, a growing number are investigated at the REED animals, indicating increased attention to the veterinary services of the region to the problem of leukemia. The decline in the number of reacting in read on leukemia, associated with replacement of the animals, RID negative cattle, and the increase in the number of BLV infected with perezarazhenie healthy cattle. The majority (over 90\%) of positively reacting animals exposed to Hematology research, although the required $100 \%$ coverage. In the field reduced the 
number of dysfunctional leukemia settlements. Monitoring studies showed that in the process of conducting the health activities of the veterinary service of the region constantly faces the problem of the reluctance of owners of cattle to replace the animals infected with BLV - healthy due to the economic losses as a result of slaughter of cattle leukemia. In drawing up the program of eradication of the disease is necessary to lay the budget funds for compensation of losses to owners of leukemic animals. Also based on diagnosis to slow the infection must lie serology studies using IFA and PCR.

Key words: leukemia, cattle, monitoring, infection, epidemic. области.

Цель проведения исследований - мониторинг лейкоза коров в Амурской

Лейкоз - медленное вирусное заболевание, поражающее коров, особенно высокомолочных животных. Вирус лейкоза (ВЛКРС) паразитирует в клетках иммунной системы лимфоидных органах.

Лейкоз наносит серьезный финансовый ущерб скотоводству, делая невыгодным развитие отрасли, создает потенциальную опасность для человека через продукты питания и непосредственного контакта с больными животными. Источником ВЛКРС являются животные.

Клиническое течение заболевания протекает в несколько периодов. Первый период - инкубационный (продромальный), начинается от заражения (проникновения инфекта в организм животного) до появления первой реакции организма, в виде преципитирующих гаммоглобулинов к оболочке вируса лейкоза, протекает от двух недель до 8 месяцев. Второй период - скрытый или латентный период болезни, начинается от появления специфических антител к ВЛКРС до появления характерных гематологических изменений и длится от 8 месяцев до 5 лет и более. Третий период выраженных гематологических изменений, характеризующихся постоянным лимфоцитозом, длится более 5 лет. Четвертый период - клинически выраженный характеризующийся развитием опухолевых поражений кроветворных и иных органов и тканей, продолжается более 7 лет.

Эпизоотическая ситуация по bovine leucosis в 2016 году на территории Российской Федерации улучшилась, однако остается довольно напряженной.

В сравнении с 2015 годом по отчётным данным субъектов Российской Федерации количество вновь выявленных неблагополучных пунктов по лейкозу крупного рогатого скота сократилось с 271 до 135. Количество больных лейкозом животных уменьшилось с 34,2 тыс. голов в 2015 году до 30,9 тыс. голов в 2016 году.

На конец 2016 года в административных территориях Российской Федерации зарегистрировано 1805 неблагополучных пунктов по лейкозу крупного рогатого скота, в конце 2015 года - 1974.

Лейкоз по ветеринарной отчётности в 2016 году регистрировался в 68 субъектах Российской Федерации [1].

По данным Гулюкина М.И. и др. в Дальневосточном Федеральном округе содержалось 2,3\% крупного рогатого скота, в т.ч. 2,2\% коров от поголовья крупного рогатого скота. В России в 2015 году было выявлено 120 неблагополучных пунктов, оздоровлено 17, вновь выявлено 18 пунктов, осталось на конец года 121 неблагополучный пункт. Наивысший уровень неблагополучия зарегистрирован в Приморском (65) и Хабаровском (36) краях. Инфицированность ВЛКРС в среднем по округу составила 4,7\% с максимумом в Хабаровском крае 26,0\%. В 2015 г. достигли гематологической стадии более 1339 коров, сдано на убой 580, осталось на конец года 1327 голов больного стада. В Амурской области выявили 1105 голов больных животных при гематологическом исследовании. Сахалинская область и Чукотский Автономный округ, свободные от лейкоза [2]. 
В связи с изложенным, возникла необходимость изучения эпизоотической ситуации по лейкозу крупного рогатого скота в Амурской области, что в конечном итоге явилось целью наших исследований.

\section{Материал и методы исследования}

Материалом для исследования служили данные ветеринарной отчетности по результатам диагностических исследований Амурской областной ветеринарной лаборатории, а также результаты наших предыдущих исследований $[3,4,5]$.

Мониторинг лейкоза крупного рогатого скота в Амурской области проводился методом эпизоотических исследований согласно схеме, предложенной ВИЭВ по трем показателям: процент инфицированности, процент больных, количество неблагополучных пунктов.

Для обработки цифровых данных применялись методы вариационной статистики и мониторинга.

\section{Результаты мониторинга и обсуждение}

Анализ ветеринарной отчетности по Амурской области, показывает, что лейкоз крупного рогатого скота является заболеванием, которое наносит животноводству большой финансовый ущерб, сдерживает развитие племенного дела и, в конечном итоге, снижает интерес к занятию скотоводством.

Результаты мониторинга эпизоотической ситуации по лейкозу крупного рогатого скота в Амурской области представлены в таблице. Согласно таблицы, с 2012 года увеличивается количество исследованных в РИД животных, что указывает на усиления внимания ветеринарной службы области к решению проблемы лейкоза крупного рогатого скота. Число реагирующих на лейкоз животных подвержено колебанию по годам, так максимум инфицированных животных пришелся на 2012 год, затем наблюдался небольшой спад на 13,4\% в 2013 и на 29,5\% в 2014 годах, затем число реагирующих в РИД животных начало возрастать в 2015 году на 4,7\% и в 2016 году на 9,6\%. Снижение числа реагирующих на лейкоз, связано с заменой животных РИД негативным скотом, а рост числа инфицированных ВЛКРС с перезаражением здорового скота.

Необходимо отметить рост гематологически исследованного с полным охватом РИД-позитивного скота в 2012 и 2014 годах, однако, в 2013, 2015 и 2016 годах полного охвата не наблюдалось. Произошло снижение диагностических исследований в 2013 году на 6,3\%, в 2015 году на 6,9\% и на 4,3\% в 2016 году. При этом максимальное количество больных животных установлено в 2012 году. В 2013 году количество больных животных снизилось на 32,7\%, 2014 году на 47,4\%, 2015 году на 78,1\%, и в 2016 году на 89,4\%. Резкое снижение числа гематологически больного скота с одной стороны свидетельствует о сокращении срока эксплуатации продуктивных животных и клинические изменения в крови просто не успевают развиться. С другой стороны об изменении свойств возбудителя инфекции и удлинения латентного периода течения болезни.

Мониторинговые исследования показали, что в процессе проведения оздоровительных мероприятий ветеринарная служба области постоянно сталкивается с проблемой - нежелания владельцев скота заменять зараженных животных на здоровых, по причине экономических потерь в результате убоя лейкозного скота. По профилактики и ликвидации лейкоза крупного рогатого скота закладывать бюджетные средства на компенсацию потерь владельцам лейкозных животных.

Таблищза

Сводные данные по лейкозу крупного рогатого ската в Амурской области.

\begin{tabular}{|c|c|c|c|c|c|c|c|c|c|}
\hline \multirow{2}{*}{ Показатели } & \multicolumn{10}{|c|}{ О Д А } \\
\cline { 2 - 10 } & 2006 & 2007 & 2008 & 2009 & 2012 & 2013 & 2014 & 2015 & 2016 \\
\hline Поголовье & 102000 & 104500 & 94400 & 87698 & 46893 & 48284 & 49134 & 49248 & 49934 \\
\hline $\begin{array}{c}\text { Исслед. в РИД, } \\
\text { всего }\end{array}$ & 54755 & 63629 & 79038 & 67760 & 116971 & 115585 & 114586 & 109756 & 111718 \\
\hline Исслед. в РИД, \% & 53,7 & 60,9 & 83,7 & 77,3 & 100 & 100 & 100 & 100 & 100 \\
\hline
\end{tabular}




\begin{tabular}{|c|c|c|c|c|c|c|c|c|c|}
\hline $\begin{array}{c}\text { Выявлено в РИД +, } \\
\text { всего }\end{array}$ & 2459 & 2664 & 3098 & 2911 & 8569 & 7402 & 6040 & 6335 & 6682 \\
\hline $\begin{array}{c}\text { Выявлено в РИД +, } \\
\%\end{array}$ & 5,0 & 4,2 & 3,9 & 4,3 & 7,3 & 6,4 & 5,3 & 5,8 & 6,0 \\
\hline $\begin{array}{c}\text { Исслед. } \\
\text { гематолог., всего }\end{array}$ & 1566 & 1145 & 1624 & 696 & 9674 & 6940 & 9933 & 5896 & 6398 \\
\hline $\begin{array}{c}\text { Исслед. } \\
\text { гематолог., \% }\end{array}$ & 56,8 & 43,0 & 52,4 & 23,9 & 100,0 & 93,7 & 100,0 & 93,1 & 95,7 \\
\hline $\begin{array}{c}\text { Выявлено } \\
\text { больных, всего }\end{array}$ & 56 & 85 & 104 & 58 & 624 & 420 & 328 & 74 & 66 \\
\hline $\begin{array}{c}\text { Выявлено } \\
\text { больных, \% }\end{array}$ & 3,4 & 7,4 & 6,4 & 8,3 & 6,4 & 6,1 & 3,3 & 1,3 & 1,0 \\
\hline $\begin{array}{c}\text { Неблагополучных } \\
\text { пунктов }\end{array}$ & 14 & 15 & 14 & 14 & 13 & 13 & 8 & 8 & 8 \\
\hline
\end{tabular}

Проведение гематологических исследований по подтверждению диагноза на вovine leucosis при наличии в лабораториях современных методов диагностики, таких как ИФА и ПЦР - теряет актуальность. В основе постановки диагноза на воvine leucosis должны лежать серологические методы исследования с использованием реакции иммунодиффузии (РИД), иммунноферментный анализа (ИФА) и полимиразной цепной реакции (ПЦР).

\section{Заключение}

Лейкоз коров в Амурской области имеет широкое распространение. Ветеринарная служба области принимает определенные меры по его ликвидации. В частности организовано поголовное исследование скота на лейкоз в РИД. Большая часть (более 90\%) положительно реагирующих животных подвергается гематологическим исследованиям, хотя необходим $100 \%$ охват. Постепенно сокращается количество неблагополучных пунктов в области.

В настоящее время необходим научно обоснованный комплексный план по ликвидации лейкоза в области, в который обязательно включить пункт о материальных компенсациях владельцам РИД-позитивного скота.

Диагноз на bovine leucosis устанавливать на основе серологических методов, а гематологическая диагностика заболевания должна иметь дополнительное значение. В связи с тем, что гематологическая картина болезни проявляется лишь у 1,0\% животных.

\section{***}

1. Отдел анализа и прогнозирования ФГБУ «Центр ветеринарии», 2017г [Электронный ресурс] //Режим доступа: http://guv.tatarstan.ru/rus/file/pub_907569.pdf

2. Гулюкин, М.И. Мониторинг эпизоотической ситуации по лейкозу крупного рогатого скота в товарных и племенных хозяйствах Российской Федерации за 2014 и 2015 годы / М.И. Гулюкин [и др.] // Ветеринария и кормление. - 2016. - № 4. С. 4-43.

3. Шульга, Н.Н. Эпизоотическая ситуация по лейкозу крупного рогатого скота в зоне Дальнего Востока / Н.Н. Шульга, И.С. Шульга, Л.П. Плавшак, С.С. Дикунина // Вестник КрасГАУ . - 2016. - № 10. C.187-192.

4. Шульга, Н.Н. Анализ эпизоотической ситуации по лейкозу крупного рогатого скота в Хабаровском крае / Н.Н. Шульга, И.С. Шульга, Л.П. Плавшак, С.С. Дикунина // Вестник КрасГАУ, 2015. - Вып.12 (10). - C. 181-185.

5. Шульга, Н.Н. Основные зоонозы юга Дальневосточного федерального округа / Н.Н. Шульга, И.С. Шульга, Л.П. Плавшак, С.С. Дикунина // Вестник ДВО РАН, 2016. № 2. - С. 116-119. 


\section{РАЗДЕЛ VІ. ПЕДАГОГИКА}

\section{Гончарова А.В., Казарова Т.А. \\ К вопросу о функционировании идиом в англоязычной литературе}

doi: $10.18411 / \mathrm{sr}-10-10-2017-09$

idsp: 000001:sr-10-10-2017-09

Известно, что любые достижения филологии при своевременном их внедрении в учебный процесс способствуют повышению эффективности и качества обучения иностранным языкам в вузе.

Новые направления в исследовании языка - прагмалингвистика и лингвистика текста - обратили внимание филологов на изучение всего текста в целом, как особого вида коммуникации.

Г.В.Колшанский отмечает, что "только в коммуникации реализуются все качества языка. ...Установка лингвистики на единственно реальную коммуникативную функцию языка - обязана поэтому учитывать не только закономерности в нормы построения текстовых единиц, например, словосочетания, предложения, но, прежде всего, их предназначение как коммуникативных единиц" (1, c.3).

Для методики преподавания английского языка в вузе большое значение имеет лингвистический анализ механизмов восприятия художественного текста. Ведь главной целью обучения на факультетах иностранных языков является практическое владение студентами иностранным языком. В частности, студенты должны уметь понимать оригинальные литературно-художественные тексты.

Как отмечают многие исследователи, все единицы художественного текста следует анализировать с точки зрения их прагматической ценности. В.Л.Наер подчеркивает, что "в более конкретном и узком смысле слова прагматическое понимается как нечто ощутимое и явно воздействующее" (2, с.106).

Опыт показывает, что фразеология является наиболее трудным моментом при восприятии иноязычного художественного текста. И наша задача - научить студентов более полно и адекватно раскрывать творческий замысел автора. К тому же определенная часть фразеологических единиц .должна закрепиться в активной лексике студентов для повышения образности речи на иностранном языке.

По справедливому замечанию Л.А.Барковой $(3$, с.11) сами ФЕ имеют в своей внутренней структуре определенные прагматические свойства. "ФЕ весьма .богаты выразительными .возможностями, и изобразительными языковыми средствами: в них наиболее ярко представлена экспрессивная функция языка" (4, с.3).

Неудивительно, что многие писатели широко используют ФЕ в своих произведениях для наиболее полного раскрытия идейно-тематического замысла.

Основой для данного сообщения послужил материал некоторых рассказов В.С.Моэма и Дж.Голсуорси. Произведения этих авторов богаты фразеологизмами. ФЕ, задействованные в рассказах, служат не только цели раскрытия авторами своих чувств, мыслей и оценки изображаемой ими. .действительности, но и воздействуют на читателя.

При выборе материала исследования мы руководствовались также причинами, практического характера. Некоторые рассказы этих писателей входят в учебный план по практике языка на старших курсах языковых вузов, многие рассказы анализируются на занятиях по интерпретации текста. Необходимо научить студентов определять роль фразеологии в раскрытии идейно-тематического содержания произведения для адекватного декодирования художественного текста.

Систематическая работа над фразеологическим материалом на занятиях предупреждает такую распространенную ошибку студентов, как дословный перевод ФЕ. Например, часто такие ФЕ, как to bring home to smb, - "убеждать, втолковывать; 
заставить понять" и to chew the food, of (fancy, etc.) - "размышлять, обдумывать" переводятся студентами дословно, что искажает смысл прочитанного.

В рассказах употребляется большое количество междометных ФЕ, многие из которых неоднократно повторяются, но с разными оттенками значения. Например, ФЕ by George! "ей-богу! боже мой! честное слово! черт возьми! вот так-так!" употребленная в одном и том же 'рассказе "A Stoic» в одном случае выражает удивление и досаду:

Alone again, old Heythorp thought: "By George! What a wavering, quavering thred paper of a fellow" (J.G., A Stoic, p.42).

А в другом фразоупотреблении эта ФЕ выражает радость и удовлетворение.

"Glad to have got that matter settled up", and out he went, and down the street. By George! He had got it: (J.G., A Stoic, p.65).

Наибольшее эстетическое воздействие на читателя оказывают ФЕ, подвергнутые всевозможным изменениям и трансформациям. Своеобразие индивидуальноавторского использования писателем ФЕ, его творческого отношения к фразеологическому материалу состоит в самом отборе $\Phi Е$, в их большей или меньшей модификации. А.В.Кунин (5) выделяет двадцать два основных типа возможного преобразования ФЕ.

Оба вышеупомянутых писателя относительно часто прибегают к окказиональному использованию фразеологизмов, и без знания ФЕ непонятой остается авторская интенция (б, с.35).

Остановимся на некоторых случаях окказионального функционирования ФЕ в рассказах В.С.Моэма и Дж.Голсуорси.

В следующем предложении противопоставляются две ФЕ: low-water mark "предел чего-либо, низкий уровень" и high-water mark - "кульминационный пункт, высший предел".

It (the latter) marked as it were the high-water mark of what was left to him of life; and this other "letter in his hand - by Jove! - Low-water mark! (J.G., A Stoic, p.87).

В данном случае противопоставление компонентов двух ФЕ "high" и "low" усиливает экспрессивность обоих фразеологизмов, с горькой иронией подчеркивает безвыходность положения старого Хейторпа.

В рассказах обоих писателей широко используется стилистический прием вклинивания. Например: to fight a battle - вступить в борьбу. p.123).

They fought a grim and silent battle with one another. (W.S.M., "The Outstation,

В данной случае раскрываема степень непримиримости двух героев друг к другу, результатом чего была гибель одного из них.

Широко используется вклинивание с усилением значения ФЕ.

Например: to speak through the nose - говорить в нос, гнусавить.

When he was that cab's age -28 or whatever it might be -he had dons most things; been up Vesuvius, driven four-in-hand, lost hie last penny on the Derby and won it back on the Oaks, known ell the dancers and operatic stare of the day fought a duel with a Yankee at Dieppe and winged him for saying, through his confounded noes, that old England was played out..." \{J.G., A Stoic, p.18)

В данном случае употребление слова "confounded" усиливает отрицательную окраску ФЕ.

Интересен прием запевы компонента ФЕ: like a bolt from the blue - как гром среди ясного неба. p.212)

Than, like a bolt from Hell, сада the Great War. (J.G., The Man Who Kept His Form,

Замена компонента в данном случае употребляется наряду с обособлением всей ФЕ, что ведет к усилению фразеологизма. Олово "hell" придаем всему обороту отрицательную коннотацию, грубоватый оттенок.

Оба писателя довольно часто используют прием двойной актуализации \{термин Л.М.Болдыревой). Например: to drink the cup to the dregs - испить чашу горести до дна. 
The boy came forward and filled him a glass of whiskey and soda. Without a word Mr.Warburton took it and drank it to the dregs (W.S.M., She Outstation, p.117).

Слово a glass является стилистическим актуализатором, буквализирующим значение ФЕ:

to tell stories - сочинять, выдумывать, рассказывать небылицы.

All the same, 50 pounds was 50 pounds, and goodness knew how much more; and what did he know of Mrs.Larne, after all, except that she was a relative of old Heythorp's and wrote stories - told them too, if he was not mistaken? (J.G., A Stoic, p.58\}

Сопоставление данной ФЕ с переменным словосочетанием "to write, stories", являющимся актуализатором двойного восприятия фразеологизма в контексте, ведет к созданию иронического отношения к миссис Ларн.

В рассказах обоих авторов довольно часто встречается сочетание нескольких стилистических приемов в одном контексте. Например:

to make a fool of smb. - поставить кого-либо в смешное положение

- I want to know what the devil yon mean by making a damned fool of me...

- Believe me, I have not made half such a damned fool, of you as you have made of yourself. (W.S.M., 2he Outstation, p.115)

Сочетание повтора $\Phi \mathrm{E}$ с усилительным вклиниванием (darned) и одновременным вклиниванием компонентов, ослабляющих (half) и усиливающих (such) значение ФЕ, создает грубую ироническую окраску.

Интересен пример аллюзии в рассказе Дж.Голсуорси "A stoic" a skeleton in the closet/cupboard - семейная тайна; неприятность, скрываемая от посторонних/

"Guardy, you were my dear Philip's father, weren't you? I've never said any thing; but of course you were. He "was so like you, and so is Jock". Nothing moved in old Heythorp's face. No pagan image consulted with flowers and song and sacrifice could have returned less answer. Her dear Philip! She bad led him the devil of a life, or he was a Dutchman! And what the deuce made her suddenly trot out the skeleton like this? (J.G., A Stoic, p.26)

Жена незаконнорожденного сына старого Хейторпа хочет любой ценой выманить деньги. Аллюзия на "семейную тайну" в сочетании с употреблением замены в ФE "to lead smb. a dog's life" -"отравить жизнь кого-либо" на "devil" (груб.) и разговорного фразеологизма "I'm a Dutchman" - "провалиться мне на этом месте" передает иронический оттенок.

Кроме того, ФЕ могут нести большую текстообразующую нагрузку. Например, в рассказе Дж.Голсуорси "She Bright Side" ФЕ the bright side - "радостные, яркие моменты" и to look on the bright side of things "бодро смотреть на жизнь, быть оптимистом" органически вплетаются в ткань повествования, выражают смысл произведения и участвуют в. его построении. Уже само использование ФЕ в заголовке говорит о расширенной метафоре. Всего, эти две ФЕ употреблены в рассказе 18 раз узуально и с различной степенью окказионального преобразования.

В свете вышеизложенного можно заключить, что отмеченные особенности функционирования фразеологических единиц в рассказах В.С.Моэма и Дж.Голсуорси представляют научный интерес и вызывают необходимость пристального изучения студентами их роли в структурно-семантической и прагматической организации текста в процессе практического овладения английский языком.

1. Колшанский Г.В. Прагматика языка: Сб .научн. тр. МПГУ (вып.IX), Лингвистика и методика в высшей школе, вып.151, М., 2008.

2. Наер В.Л. Прагматический аспект английского газетного текста: МГУ, Коммуникативные и прагматические особенности текстов различных жанров. Вып.178, М., 2012.

3. Баркова Л.А. Прагматический аспект использования фразеологизмов в рекламных текстах. АКД. М., 2012.

4. Алиев К.Ю. Стилистические особенности фразеологии в художественной литературе. АКД, Баку, 2008.

5. Кунин А.В. Основные понятия фразеологической стилистики. - Кн.: Проблемы лингвистической стилистики/Материалы научной конференции, М., 2011. с.71-75, переизд. №10.

6. Москальская О.И. Семантика текста. Сборник СПбу, 2012, № б. 


\section{Кохичко А.Н. \\ Ценность как базовая категория аксиологического подхода к содержанию начального обучения русскому (родному) языку}

Мурманский арктический государственный университет (Россия, Мурманск)

doi: $10.18411 / \mathrm{sr}-10-10-2017-10$

idsp: 000001:sr-10-10-2017-10

\section{Аннотация}

В статье в русле культурологического (культурно-исторического) и аксиологического подходов к содержанию образования осмысливается понятие «ценности», определяющей основное содержание духовно-нравственного развития и воспитания личности обучающихся в условиях реализации федеральных государственных образовательных стандартов второго поколения.

Ключевые слова: федеральный государственный образовательный стандарт, аксиологический подход к содержанию начального обучения русскому (родному) языку, ценность, «отношения» к миру,«проживание и осмысление» ценности.

В новых федеральных государственных образовательных стандартах в контексте культурологического (культурно-исторического) и аксиологического подходов к содержанию образования были определены цель, задачи, основные направления и ценностные ориентиры (основы) духовно-нравственного развития и воспитания обучающихся. Тем не менее, несмотря на многочисленную аксиологическую терминологию и весьма разнообразные ценности (системы ценностей), представленные в образовательных стандартах второго поколения, обращает на себя внимание отсутствие категории «ценность», определяющей основное содержание духовно-нравственного развития и воспитания личности обучающихся, в глоссариях «фундаментальных социальных и педагогических понятий» «Концепции духовно-нравственного развития и воспитания личности гражданина России» и «используемых понятий, обозначений и сокращений» «Основной образовательной программы образовательного учреждения».

Значимость и неопределенность «ценности» (Prezzo, Vale, Valeur, Valor, Value, Wert), одного из центральных понятий аксиологии, для наполнения конкретным содержанием современного образовательного процесса, русскому языку как родному в частности, потребовало нашего обращения к осмыслению данного понятия в различных аспектах научной мысли.

При традиционном разграничении материальных, духовных и культурных ценностей, В.Ф. Сержантов выделяет материальные (орудия и средства труда, вещи непосредственного потребления) и духовные (политические, правовые, моральные, эстетические, философские и религиозные идеи) ценности [15].

Н.А. Бердяев дефинирует духовные, социальные и материальные ценности[2, с. 171]. Сегодня в самом общем виде, как отмечает В.Л. Иванов, выделяются ценности материальные, духовные и социальные. В материальных ценностях, по мнению философа, «выражается отношение человека к вещам и процессам окружающего мира с точки зрения их способности удовлетворить его жизненно важные потребности < .. > Социальные ценности обеспечивают деятельность человека как социального существа. Наконец, благодаря духовным ценностям человек реализует себя как творческую и нравственную индивидуальность: созидает (и интерпретирует) художественные произведения, оценивает поведение окружающих и свое собственное и т. д.»[7, с. 4-5].

«В широком понимании в качестве ценности, - в изложении Е.С. Рапацевича, могут выступать не только абстрактные привлекательные смыслы или ситуативные ценности, но и стабильно важные для индивида конкретные материальные блага. В более узком значении принято говорить о ценностях как о духовных идеях, заключенных в 
понятиях, которые имеют высокую степень обобщения. Формируясь в сознании, эти ценности постигаются в ходе освоения культуры»[12, с. 659].

И все же, такие «общие» понимания ценности, по нашему мнению, не раскрывают сущности данной категории, о сложности и неоднозначности которой свидетельствуют и многочисленные подходы к ее классификации.

Так, М.И. Дьяченко и Л.А. Кандыбович, помимо материальных и духовных, разграничивают природные ценности.

Потребительную и меновую ценности находим у А. Мануилова.

В трактовке Э.Л. Радлова, «помимо субъективных ценностей, могут быть и общепризнанные ценности; к ним относятся этические, эстетические и экономические ценности».

«Двумя полюсами ценностного отношения человека к миру», констатирует О.Г. Дробницкий, являются предметные и субъектные ценности (ценности сознания, или ценности-представления)[4, с. 44-45; 6, с. 733]. При этом предметные ценности выступают как объекты ценностного отношения человека к миру. Субъектные ценности - выражение того же отношения со стороны субъекта, в которых интересы и потребности переведены на язык идеального, мыслимого и представляемого.Наряду с представленными выше, философом выделяются материальные и духовные, производственно-потребительские (утилитарные), социально-политические, познавательные, нравственные, эстетические и религиозные ценности[5, с. 462].

В.П. Тугаринов классифицирует ценности жизни и ценности культуры: материальные и духовные, группируемые на основе составляющих человека - тела и души - и социально-политические ценности. Отдельно философом выделяется группа конкретных ценностей[18, с. 23]. В другой систематике этого же автора находим ценности наличные (экзистенциальные), целевые и нормативные. Экзистенциальные ценности, в понимании В.П. Тугаринова, существуют во всех областях жизни и деятельности. К ним относятся все социально-политические и духовные ценности[17, с. 23-44].

Общечеловеческие, непреходящие, высшие ценности, которые сохраняют положительное значение во все времена и для всех людей и небольшую группу их антиподов (антиценностей) систематизирует С.Ф. Анисимов. При этом для обозначения ценностно-высшего философом группируются абсолютные (идеальные) и релятивные (относительные) ценности, обусловливаемые обстоятельствами места и времени, интересами, ценностными ориентациями людей[1, с. 43-44].

Для эмпирического исследования, позволяющего определить ценности общества в период кризиса, Н.И. Лапиным обозначены базовые ценности[9].

В.Н. Сагатовский[14], вычленяя ценностно-ориентационный аспект, объединяет ценности по различным видам деятельности: утилитарные; познавательные; управленческие; нравственные; эстетические; потребительские; творческие.

Д.А. Леонтьев разграничивает три формы существования ценности: общественный идеал, как выработанное общественным сознанием, содержащееся в нем абстрактное представление об атрибутах должного в различных сферах общественной жизни; предметное воплощение ценности, предстающее в объективированной форме в виде произведений материальной и духовной культуры либо человеческих поступков, и личностные ценности[10] и т. д.

Кроме того, в современной научной мысли мы находим ценности:

- витальные, социальные, политические, моральные, религиозные, эстетические;духовные - общечеловеческие, национальные, сословноклассовые, групповые, семейные, индивидуально-личностные (Н.Ф. Алефиренко);

- внутринаучные (когнитивные) (В.П. Кохановский);

- высшие (Б-ценности - бытия), низшие (Д-ценности - дефициентные) (А. Маслоу); 
- «дифференцирующие», «интегрирующие» (Н.И. Лапин);

- гуманитарного образования; кардинальные, субкардинальные, этосные (Н.С. Розов);

- жизненные (Е.А. Воронова);

- конкретно-исторические (В.Б. Шапарь, В.Е. Россоха, О.В. Шапарь);

- конкретные, абстрактные (К.А. Абульханова-Славская);

- конкретные жизненные - абстрактные, профессиональной самореализации - личной жизни, индивидуальные - межличностных отношений, активные - пассивные (Д.А. Леонтьев);

- личностные, общественные (Р.Н. Бунеев, Д.Д. Данилов, З.И. Курцева, Т.Д. Шапошникова, О.В. Чиндилова);

- малой родины, отечественные, родного очага, сугубо личностные (В.Т. Фоменко, И.Ю. Кулагина);

- материальные, духовные, культурные (В.Л. Абушенко, С.И. Ожегов, Н.Ю. Шведова);

- морального сознания (С.С. Аверинцев, И.С. Кон и др.);

- народной культуры (Г.И. Батурина, Т.Ф. Кузина);

- науки (В.А. Белов, В.П. Кохановский);

- общеродовые (М.Ю. Новицкая);

- объективно существующие, субъективно значимые (Я. Гудечек);

- основные национальные (Л.В. Трубайчук);

- официально признанные, осознаваемые (религиозные, гуманистические), действительные, бессознательные (порожденные социальной системой) (Э. Фромм);

- первичные, вторичные, третичные, несущественные (К. Ситерам, Г. Когделл);

- познания, политики, цивилизации, экзистенции, PR, церкви, социального действия, жизни (В.В. Ильин);

- смысла жизни; творчества, переживания, отношения (В. Франкл);

- целевые (мыслимые - желаемые, возможные), существующие (наличные актуальные);ценности-цели, ценности-идеалы, ценности-желания, ценности должного (нормативные) (В. Момов);

- ценности - цели, ценности - средства (М. Рокич);

- ценности-идеалы, ценности-свойства, ценности-способы поведения (С.С. Бубнова);

- этические - межличностного общения - профессиональной самореализации, индивидуалистические - конформистские - альтруистические, самоутверждения - принятия других, интеллектуальные непосредственно-эмоционального мироощущения (Д.А. Леонтьев) и др.

На основании изложенного выше можно сделать вывод о том, что однозначно определить сферу действительности, обозначаемую понятием «ценность», чрезвычайно сложно. Тем не менее, несмотря на различные многочисленные: информационные (В.И. Першиков, В.М. Савинков и др.); культурологические (М.Б. Ладыгин, О.М. Ладыгина и др.); педагогические (Е.В. Бондаревская, Р.Н. Бунеев, Д.Д. Данилов, З.И. Курцева, Т.Д. Шапошникова, О.В. Чиндилова; Е.А. Воронова, В.А. Караковский, А.В. Кирьякова, З.И. Равкин, Е.С. Рапацевич, В.Т. Фоменко, И.Ю. Кулагина, Н.Е. Щуркова и др.); политологические (Ю.И. Аверьянов и др.); психологические (М.И. Дьяченко, Л.А. Кандыбович; М.И. Еникеев, Л.А. Карпенко, И.М. Кондаков, Р.С. Немов, В.Б. Шапарь, В.Е. Россоха, О.В. Шапарь и др.); социологические (А.С. Айзикович, Г.М. Андреева, В.И. Антонюк; Н. Аберкромби, С. Хилл, Б. Тернер; Г.В. Осипов и др.); философские (А.К. Абишева, С.Ф. Анисимов, Н.А. Бердяев, О.Г. Дробницкий, Е.В. Золотухина-Аболина, В.Л. Иванов, Д.А. Леонтьев, А. Мануилов, С.Я. Матвеева, В.Н. Сагатовский, В.П. Тугаринов, С.Л. Франк, И.Т. Фролов и др.); экономические (Б. Берман, Дж. Эванс; М.Б. Вуд, П.Р. Палажченко, Б.А. Райзберг, Л.Ш. Лозовский, Е.Б. Стародубцева и др.); эстетические (М.Ф. Овсянников, 
В.А. Разумный и др.); этические (С.С. Аверинцев, А.В. Адо, М.И. Андриевская и др.); этнопсихологические (В.Г. Крысько, Э.А. Саракуев) и другие представления о ценности, мы в рамках аксиологического подхода к обучению русскому (родному) языку можем обозначить следующие положения:

1. В качестве ценности могут выступать различные сферы действительности (окружающего, внешнего мира): объекты, предметы, явления (стороны, свойства предметов и явлений) природы и общества; (формы проявления) отношения между субъектом и объектом (отношение человека к вещам и процессам окружающего мира; все многообразие общественных отношений); (идеальные) представления о предпочитаемых благах и способах их получения; момент значимости одного явления для бытия другого; идеи и побуждения; установки и оценки, императивы и запреты, цели и проекты, выраженные в форме нормативных представлений; способы и критерии оценивания соответствующих явлений; способы и критерии оценок и предписания объектов; предпочтение личностью или обществом определенного образа поведения или конечного состояния; целеполагающая деятельность человека, поведение окружающих и свое собственное и др.

2. Существенными признаками (качествами, свойствами, особенностями, спецификами) ценности являются: полезность, нужность людям (определенного общества, класса, отдельной личности); (человеческая, социальная, культурная, хозяйственная) значимость (для человека, класса, группы, общества в целом) какого-либо объекта; нормативность, предписательно-оценочная сторона явлений общественного сознания; концентрирование предшествующего опыта субъекта; целеполагание деятельности людей, определение образа поведения или конечного состояния и др.

3. Функциональные предназначения ценности заключаются в том, чтобы: быть полезной, нужной, удовлетворять какие-либо (определенные, жизненно важные, хозяйственные) потребности (стремления, интересы, цели)человека, класса, общества; выступать мерой зависимости одного явления от другого; быть для людей действительностью, нормой, целью, идеалом, (повседневным) ориентиром (направленностью) поведения и деятельности (в предметной и социальной действительности); быть основанием целеполагающей деятельности людей, определять образ поведения или конечного состояния, в противоположность другому типу поведения или состоянию, обеспечивать деятельность человека как социального существа, выступать для индивида (субъекта) внутренним и внешним (общественным) регулятивом его отношений с миром; реализовывать себя как творческую и нравственную индивидуальность; активно и сознательно преобразовывать мир и самого себя в соответствии со значимыми для себя идеальными представлениями и др.

Несомненно, многочисленные и разнообразные классификации ценностей имеют большое значение для понимания природы ценностей, осмысления личностного, социального и культурного значения определенных явлений действительности, отношений между субъектом и объектом, расширения границ познания универсальной взаимозависимости явлений. Тем не менее, как отмечает В.К. Шохин, сегодня область аксиологии, «охватывает применение понятия «ценность» и прилагательного «ценностный» ко всем практически сферам человеческого познания и деятельности (от политики до медицины), а потому закономерно ведет к «обесцениванию ценностей» как глубинно-личностных атомов человеческой экзистенции и создает кризис в аксиологии, преодолимый только серьезными «антиинфляционными» мерами, связанными в первую очередь с «лечением» самого современного языка и серьезной работой над категориями аксиологии»[21, с. 24-25].

Соглашаясь с рассуждениями В.К. Шохина, считаем чрезвычайно важным для формирования национального (этнического) самоопределения младших школьников при обучении русскому (родному) языку, определиться с изначальной методологической дефиницией центрального понятия теории ценностей, обратившись при этом к русскому 
языку и философскому пониманию «щенности» как базовой категории аксиологии. Анализ содержания представлений о ценности позволит установить, что именно обозначается этим словом, каким комплексом качеств характеризуется данная категория, и какие функции она выполняет.

Согласно Э.Л. Радлову[19, с. 265], под ценностью, понимается «результат оценки, т. е. определение отношения известного объекта к стремлению, потребности или целям человека. Объект имеет ценность, поскольку он служит к удовлетворению стремлений и целей. Таким образом, вне области стремлений нет ценностей».

«Категория ценности, - в изложении В.А. Василенко, - раскрывает один из существенных моментов универсальной взаимозависимости явлений, а именно момент значимости одного явления для бытия другого»[3, с. 42].

В.П. Тугаринов [16, с. 276]трактует ценности как «суть предмета, явления и их свойства, которые нужны людям определенного общества или класса и отдельной личности в качестве средств удовлетворения их потребностей и интересов, а также - идеи и побуждения».

Ценности, подчеркивается в «Кратком словаре по философии» под общей редакцией И.В. Блауберга, И.К. Пантина, - «явления как материального, так и духовного характера, обладающие положительной значимостью, т.е. способные удовлетворять какие-либо потребности человека, класса, общества, служить их интересам и целям»[8, с. $381]$.

Как «специфически социальные определения объектов окружающего мира, выявляющие их положительное или отрицательное значение для человека и общества» истолковываются ценности в «Философском словаре» под редакцией И.Т. Фролова. «По отношению к субъекту (человеку), - находим далее, - ценности служат объектами его интересов, а для его сознания выполняют роль повседневных ориентиров в предметной и социальной действительности, обозначений его различных практических отношений к окружающим предметам и явлениям»[20, с. 534].

«По существу, - подытоживает О.Г. Дробницкий[6], - всё многообразие предметов человеческой деятельности, общественных отношений и включенных в их круг природных явлений может выступать в качестве «предметных ценностей» как объектов ценностного отношения, т. е. оцениваться в плане добра и зла, истины или неистины, красоты или безобразия, допустимого или запретного, справедливого или несправедливого» и т. д.».

Если «в обыденном сознании и обычном словоупотреблении, - замечает С.Ф. Анисимов, - под ценностями чаще всего подразумевают предметы, обладающие какиминибудь полезными для человека свойствами», то «в философии понятие ценности имеет более отвлеченный смысл, близкий к понятию «значение», <..> положительное значение данного предмета или его свойства для конкретного субъекта деятельности (индивида, класса, общества) с точки зрения того, насколько этот предмет способен удовлетворять определенную потребность. Поэтому, - продолжает философ, - можно сказать, что понятие ценности отражает не столько сам факт возникновения ценностного отношения между предметом и потребностью в нем, сколько определенное качество этого отношения (выделено нами), которое и фиксируется в сознании в виде суждения об этом качестве оценки»[1, с. 40]. При этом под отношением между человеком и миром в истории и современной лексике русского языка понимается:

1. Составление своего представления о ком-либо, чем-либо, внутреннее оценивание, проявление своего чувства по отношению к кому-либо, чему-либо, симпатии или антипатии; принятие чего-либо каким-либо образом. [Лариса] Поддержите меня, мне нужно одобрение, сочувствие; отнеситесь ко мне нежно, с лаской! А. Островский. Плотник весь напрягся и внимательно слушал, разиня рот. Он не знал, как отнестись к этой речи, - верить ей или смеяться над нею? С. Скиталец. 
2. Взаимная связь, зависимость разных величин, предметов, действий, явлений, соотношение между чем-либо. Если взять наличную массу каторжных за все время ее пребывания на острове, то отношение бегавших в разное время к общему составу выразится не менее, как в шестидесяти процентах. А. Чехов.

3. Тот или иной характер поведения, обращения кого-либо с кем-либо, чемлибо. Один из моих товарищей-экспертов обратил мое внимание на грубое отношение прокурора к подсудимым. А. Чехов.

4. Взгляд на что-либо, восприятие, понимание чего-либо. Трудно во всемирной литературе найти двух художников, у которых отношение к жизни было бы до такой степени противоположно, как у Толстого и у Достоевского. В. Вересаев.

5. Связи между кем-либо, чем-либо, образующиеся в процессе общения, при контактах, какой-либо деятельности . Дома́ Левиных и Щербацких были старые дворянские московские дома и всегда были между собою в близких и дружеских отношениях. Л. Толстой.

6. Причастность к чему-либо, связь с кем-либо, чем-либо; принадлежность, касательство. Мы растрату рассматриваем, так сказать, теоретически, без всякого отношения к личностям. Н. Островский.

7. Отдельная сторона, точка зрения, аспект. В композиционном отношении доклад проигрывает всем прочим.

8. Деловая, служебная бумага с запросом или уведомлением о чем-либо. Несколько занумерованных отношений и предписаний полетело в разные стороны. И. Тургенев. Из готового уже дела велено было ему сделать какое-то отношение в другое присутственное место. Н. Гоголь[Даль В.И., Евгеньева А.П., Ожегов С.И., Стоян П.Е., Ушаков Д.Н.,Шведова Н.Ю.] и др.

Приняв за основу базовое (первое) истолкование «отношения», можно констатировать, что ценность, «в целостной структуре мироотношения и мировоззрения людей» (в аксиологическом определении В.П. Плотникова[13, с. 196] - категория, возникающая в результате «внутреннего оценивания» (природа ценности) и способствующая мотивации поступков и действий человека (место и роль ценности). Объединяющим «мироотношения и мировоззрения людей» является «смысл».

Делая обобщение, согласимся с утверждением Н.О. Лосского о том, что ценность «есть нечто всепроникающее, определяющее смысл и всего мира в целом, и каждой личности, и каждого события, и каждого поступка. Всякое малейшее изменение, вносимое в мир каким бы то ни было деятелем, - отмечает философ, - имеет ценностную сторону и предпринимается не иначе как на основе каких-либо ценностных моментов и ради них» $[11$, с. 7$]$. Осмысление ценности, как смысла мы находим и в многочисленной научной мысли (Б. Г. Ананьев, Н.А. Бердяев, Б.С. Братусь, Г.Л. Будинайте, Т.В. Корнилова, Я. Гудечек, М.И. Еникеев, Е.А. Климов, В.Е. Клочко, Б.С. Круглов, Д.А. Леонтьев, А.А. Леонтьев, В.С. Мухина, И.Г. Петров, Е.С. Рапацевич, В.Н. Сагатовский, А.В. Серый, С.Л. Франк, В. Франкл, Н.Л. Худякова, М.С. Яницкий и др.).

Для методологических основ формирования национального (этнического) самоопределения младших школьников при обучении русскому языку как родному, особое значение приобретает то обстоятельство, что связь ценности со смысловой сферой личности не противоречит современной парадигме личностно развивающего образования, определяющей своеобразие подхода, который применяется в начальном образовании (И.В. Абакумова, К.А. Абульханова-Славская, Н.А. Алексеев, Ш.А. Амонашвили, А.Г. Асмолов, В.А. Беликов, М.Н. Берулава, Л.И. Божович, Е.В. Бондаревская, С.К. Бондырева, Р.Н. Бунеев, Р.Н. Бунеева, О.С. Газман, В.В. Давыдов, Л.В. Занков, И.А. Зимняя, В.П. Зинченко, Е.Б. Моргунов, Т.Г. Калугина, В.Е. Клочко, Г.Б. Корнетов, Е.А. Крюкова, А.А. Леонтьев, В.Э. Мильман, Н.Д. Никандров, В.В. Рубцов, А.В. Петровский, В.Н. Сагатовский, В.В. Сериков, Г.Н. Сериков, В.И. Слободчиков, Л.В. Трубайчук, Д.И. Фельдштейн, Е.Н. Шиянов, Д.Б. Эльконин, И.С. Якиманская, Е.А. Ямбург и др.). 
Отличительной особенностью данного подхода «является направленность на формирование мотивационно-смысловой стороны учебной деятельности», которая «трансформируется из присвоения социокультурного опыта в процесс саморазвития личности». При этом смыслообразующая деятельность учащихся как обогащение структур сознания и выход за пределы собственного «Я» обеспечивается созданием образовательных пространств разного уровня (урок как микропространство, исследовательская деятельность учащихся вне урока, дистанционное обучение), а содержание обучения рассматривается как «субстрат, питающий смысловое развитие учащихся» (И.В. Абакумова). Средствами обучения, включающего процессы смыслообразования, смыслопорождения и смыслотворчества, выступают смыслы и их формы (переживания, саморефлексия, интроекция, творческие акты).

Подводя итог, отметим, что в качестве ценности выступает мыслительный образсубъекта (индивида и общества (класс, группа, слой, этнос и др.), в котором фиксируется отношение этого субъекта с какими-либо объектами. Основу этой связи составляет то, что объект переживается («проживается») субъектом как необходимый, значимый, имеющий смысл для субъекта.

Данное понимание ценности должно способствовать организации эмоциональноценностного процесса обучения русскому языку как родному в русле культурологического (культурно-исторического) и аксиологического подходов к содержанию образования через «отношения» к миру, его непосредственное «проживание», который, по точному замечанию А.А. Леонтьева, обучающийся«переживает и осмысляет для себя».

$$
* * *
$$

1. Анисимов, С.Ф. Духовные ценности : производство и потребление [Текст] / С.Ф. Анисимов. - М. : Мысль, 1988. - 253 с.

2. Бердяев, Н.А. Судьба России : Опыты по психологии войны и на-цио ᄀнальности [Текст] / Н.А. Бердяев. - М. : Мысль, 1990. - 208 с.

3. Василенко, А.В. Ценность и ценностные отношения [Текст] / А.В. Василенко // Проблемы ценности в философии. - Л. : Наука, АН СССР, 1966. - С. 44-98.

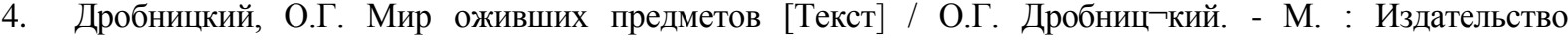
политической литературы, 1967. - 351 с.

5. Дробницкий, О.Г. Ценность [Текст] / О.Г. Дробницкий // Философ-ская энциклопедия : в 5 т. / гл. ред. Ф.В. Константинов. - М. : Со ᄀветская эн-циклопедия, 1960-1970. Т. 5. - С. 462-463.

6. Дробницкий, О.Г. Ценность / [Текст] / О.Г. Дробницкий // Философлский энциклопедический словарь / редкол. : С.С. Аверинцев, Э.А. Араб-Оглы, Л.Ф. Ильичев и др. - 2-е изд. - М. : Советская энциклопедия, 1989. - С. 732-733.

7. Иванов, В.Л. Аксиология [Текст] / В.Л. Иванов // Словарь философских терминов / научн. ред. проф. В.Г. Кузнецов. - М. : ИНФРА-М, 2007. - С. 4-6.

8. Краткий словарь по философии [Текст] / под общ. ред. И.В. Блауберга, И.К. Пантина. - 4-е изд. - М. : Политиздат, 1982. $-431 \mathrm{c.}$

9. Лапин, Н.И. Модернизация базовых ценностей россиян [Текст] / Н.И. Лапин // Социологические исследования. - 1996. - № 5. - С. 3-23.

10. Леонтьев, Д.А. Ценность как дисциплинарное понятие многомерной реконструкции [Текст] / Д.А. Леонтьев // Вопросы философии. - 1996. - № 3. - С. 15-25.

11. Лосский, Н.О. Ценность и бытие : Бог и Царство Божие как основа ценностей [Текст] / Н.О. Лосский. Харьков : Фолио; М. : ООО «Фирма «Издательство АСТ», 2000. - 864 с.

12. Педагогика : Большая современная энциклопедия [Текст] / сост. Е.С. Рапацевич. - Мн. : Современное слово, 2005. $-720 \mathrm{c}$.

13. Плотников, В.И. Ценностный мир человека и его судьба [Текст] / В.И. Плотников // Двенадцать лекций по философии. - Екатеринбург : Изд-во Уральской государственной юридической академии. - 1996. С. $193-224$.

14. Сагатовский, В.Н. Системный подход к классификации ценностей [Текст] / В.Н. Сагатовский // Научные исследования и человеческие потребности. Материалы к симпозиуму ЮНЕСКО. - М. : ВНИИ системных исследований, 1979. - 119 с.

15. Сержантов, В.Ф. Человек, его природа и смысл бытия [Текст] / В.Ф. Сержантов. - Л. : Изд-во Ленинградского ун-та, 1990. - 360 с. 
16. Тугаринов, В.П. Избранные философские труды [Текст] / В.П. Тугаринов / предисл. А.О. Бороноева : ЛГУ им. А.А. Жданова. - Л., 1988. - 343 с.

17. Тугаринов, В.П. Соотношение категорий диалектического материа-лизма [Текст] / В.П. Тугаринов. - Л. : Изд-во Ленинград. гос. ун-та, 1956. - 122 с.

18. Тугаринов, В.П. Теория ценностей в марксизме [Текст] / В.П. Туга-ри ᄀнов. - Л. : Изд-во Ленинград. гос. ун-та, 1968. - 124 с.

19. Философскій словарь логики, психологіи, эстетики и исторіи философіи [Текст] / подъ ред. Э.Л. Радлова. - С.-Петербургъ, 1911. - 284 с.

20. Философский словарь [Текст] / под ред. И.Т. Фролова. - 5-е изд. - М. : Издательство политической литературы, 1986. - 590 с.

21. Шохин, В.К. Аксиология [Текст] / В.К. Шохин // Философия : энциклопедический словарь / под ред. А.А. Ивина. - М. : Гардарики, 2006. - С. 22-25.

Тарасенко Н.Г.

Методологические основы формирования онтологической составляющей глобально-ориентированного мировоззрения личности в современном образовательном процессе

Белгородский государственный научно-исследовательский университет doi: $10.18411 / \mathrm{sr}-10-10-2017-11$

(Россия, Белгород)

idsp: 000001:sr-10-10-2017-11

\section{Аннотация}

В статье акцентируется внимание на глобализации как тенденции развития современной цивилизации, обусловливающей необходимость формирования глобальноориентированного мировоззрения личности. Автор аргументирует точку зрения, в соответствии с которой в роли методологической основы нового типа мировоззрения в целом и его онтологической составляющей, в частности, способны выступить глобальные идеи философии космизма. В статье раскрывается сущностное содержание этих идей и определяются соответствующие блоки знаний содержания образования, нацеленного на формирование онтологической составляющей глобально-ориентированного мировоззрения личности.

Ключевые слова: глобализация; глобально-ориентированное мировоззрение личности; онтологическая составляющая мировоззрения; философия космизма; методологическая основа; картина мира; образовательный процесс

Совершенствование общества XXI века связывается с образовательной парадигмой, отвечающей тенденциям развития мировой цивилизации. Формирование востребованного временем мировоззрения личности исконно является основополагающей задачей педагогики и системы образования.

Общепризнан вывод современных учёных о том, что объективной и приоритетной по степени значимости характеристикой современного этапа развития человечества является глобальность (Э.В. Гирусов, В.И. Данилов-Данильян, Г.В. Номеровская, А.Л. Пастухов, А.Л. Романович и др.). В XXI веке глобализация представляет собой главный фактор развития человечества как планетарного единства. С внешней объективной стороны происходит глобализация земных связей человека. Поскольку именно человек в конечном итоге творит глобальный мир, то появляется необходимость глобализации сознания человека. Следовательно, формирование отвечающего вызовам времени мировоззрения личности предполагает отражение в образовательном процессе глобальных тенденций мирового развития.

Для педагогической науки важно понимание того, каким образом внешняя глобализация как объективный процесс сопряжена с её субъективной стороной мировоззрением личности. Приоритетная задача педагогической науки состоит в том, 
чтобы осмыслить организующую роль феномена глобализации в разработке концепции формирования нового типа мировоззрения личности.

В соответствии с современными научно-философскими представлениями глобализация выступает конституирующей моделью современного мировоззрения. А.Л. Пастухов рассматривает глобализацию как «мировоззренческий феномен, выражающий процесс роста личностной причастности человека к событиям взаимосвязанного, взаимозависимого мира» $[4,8]$. Это означает, что феномен глобализации определяет содержание мировоззрения современного человека, его ценностно-смысловую основу.

Проблемы глобально-ориентированного образования исследуются современными отечественными учёными (И.Ю. Алексашина, С.Б. Гершунский, В.М. Данильченко, Г.Г. Дроздова, С.Л. Зарецкая, Т.Е Зорина, Е.Б., Спасская, Я.М., Колкер, Е.С. Устинова, А. П. Лиферов, В. Лысенко, М.П. Пушная, С.В Тарасов, Н.Л. Федотова). По отношению к современному человеку ученое сообщество выдвигает требование мыслить и действовать в глобальном, космо-планетарном масштабе.

Согласно М.П. Пушной, глобально-ориентированным мировоззрением называется целостное мировоззрение, подразумевающее единство и взаимосвязь всех процессов и явлений мира. Глобальной грамотностью, с точки зрения автора, называется обладание глобально-ориентированными знаниями; умение глобально ориентировать знания, т.е. находить место новым знаниям в глобально-ориентированном мировоззрении и видеть применение им в различных сторонах жизнедеятельности [5, 9-10].

Разрешение актуальной на сегодняшний день педагогической проблемы предполагает поиск идей, единство которых послужило бы методологической основой формирования глобально-ориентированного мировоззрения личности. Такая характеристика как глобальность присуща идеям философии и педагогики космизма. Как известно, яркими представителями этого направления мировой мысли являются Н.А. Бердяев, В.С. Соловьев, Н.Ф. Федоров, В.И. Вернадский, К.Э. Циолковский, Н.А. Умов, Н.Г. Холодный, А.Л. Чижевский, А. Бергсон, Дж. Дана, Тейяр де Шарден, Э. Леруа и др.

Согласно выводам ряда исследователей (М.А. Абрамов, Ф.И. Гиренок, Э.В. Гирусов, В.П. Казначеев, В.В. Казютинский, О.Д. Куракина, Н.Н. Моисеев, Ю.В. Олейников, А.А. Оносов, В.Н. Сагатовский, В.С. Степин, А.И. Субетто, С.Г. Семенова, А.Д. Урсул и др.), идеи мирового космизма обладают тем методологическим потенциалом, реализация которого в образовательном процессе может стать эффективным условием формирования нового отвечающего требованиям времени мировоззрения личности.

С точки зрения учёных, актуальность философии космизма объясняется тем, что в рамках этого направления знаний была предпринята попытка осмысления тех проблем, которые в настоящее время приобрели характер глобальных. Идеи философии космизма обрели актуальность, поскольку они оказались в русле напряженных поисков духовных ориентиров и ценностей современного человека, а также перекликаются с идеями коэволюции.

Как известно, целостное мировоззрение предполагает единство таких его составляющих, как: онтологическая, гносеологическая, аксиологическая и праксиологическая.

Создание теоретико-педагогической концепции формирования глобальноориентированного мировоззрения личности на основе идей философии и педагогики космизма требует выявления методологических оснований каждой из этих составляющих.

Вместе с тем в современной литературе отмечается, что в традиционноочерченном пространстве познания образования, для которого характерна установка на гносеологию, аксиологию, праксиологию, к сожалению, недостаточное внимание уделяется антропо-онтологическому аспектам [1,7]. Вместе с тем, онтологическая составляющая имеет особую значимость в разрешении проблемы формирования 
мировоззрения личности, поскольку указывают место и раскрывают роль человека в структуре бытия.

Принимая во внимание возникшее противоречие, обратимся к выявлению методологических основ онтологической составляющей глобально-ориентированного мировоззрения личности.

Онтология мировоззрения кроется в системе отношений Мир - Человек. Методологическое положение представителей философии космизма о единстве мироздания предполагает понимание целостности Мира в масштабах Вселенной.

Представители философии космизма стоят на позиции признания единства Вселенной, утверждая, что все разнообразие предметов и явлений природы, общества и человеческого сознания - суть проявления целостной всемирной субстанции: «Всё порождено Вселенной, она начало всех вещей, от неё всё и зависит» [8,308].

В.И.Вернадский рассматривает Землю как космическое тело и исследует влияние на него остального Космоса. Учёный указывает на обусловленность строения планеты Земля макроскопическим строением Космоса. «В составе нашей планеты и земной коры, в частности, - пишет В.И.Вернадский, - открываются указания на явления, далеко выходящие за её пределы. Мы не можем их понять, если не отойдем от области земных, даже планетных явлений, не обратимся к строению всей космической материи, к её атомам, к их изменению в космических процессах...» $[2,13]$.

Учёные (Л.В. Голованов, О.Д.Куракина) характеризуют космизм как специфическое «миросозерцание» или «мировосприятие», при котором осознаётся единство всего во всём. С точки зрения современных исследователей, русский космизм во всех своих основных положениях восходит к идее всеединства - свободному объединению в Абсолюте всех элементов бытия.

На основе исследования концепции всеединства Г.Ф. Гараева приходит к следующему мнению: «В.С. Соловьёв отождествлял принцип всеединства с принципом целостности, утверждающим, что каждый предмет есть лишь выделившаяся часть целого, которое включает независимое от какого-то данного предмета бытие других явлений, предметов, процессов, с которыми он связан и взаимодействует» [3, 307].

Статус глобальной идеи в философии космизма имеет идея об исходном единстве человека и Космоса. Неразрывная связь человека и Космоса в философии космизма является одним из проявлений целостности мира. Согласно космизму, человек по своей природе космичен. Он включён в мировой порядок, гармонично связан с природой Космоса и образует с ней единство. Человек более не является центром мироздания, он представляет собой органическую часть Космоса.

Н.Г. Холодным разрабатывается концепция антропокосмизма. Антропокосмизм характеризуется учёным как новое миропонимание, отличное от антропоцентризма, где человек рассматривается в качестве центра мироздания и акцент делается на привилегированном положении человека в мире. Характеризуя основную идею антропокосмизма, Н.Г. Холодный пишет: «Человеческий микрокосм - органическая часть всего великого мирового целого, нераздельно с ним связанная и ему же обязанная своим существованием. Нет и не должно быть никаких границ между миром человека и всей остальной Вселенной, и поэтому нельзя противопоставлять их друг другу» $[7,199]$.

Философия космизма отражает представление о том, что существование человека на Земле - продукт деятельности всего Космоса, всей глобальной эволюции. Эволюция планеты Земля рассматривается представителями этого направления знания как единый космический, геологический, биогенный и антропогенный процесс. Согласно философии космизма, человек является биосферным, планетарным, солярным и космическим существом. Он обладает разумом и волей, является активным субъектом в системе «общество-природа». Космисты указывают на такую возможность человека как возможность свободного доопределения Мира. При этом природа также играет роль действующего субъекта и воздействует на такой объект как человек. 
Bce, что разъединяет человека и общество, человека и природу, Н.Г.Холодный относит к антропоцентрическим процессам (эгоизм, честолюбие, пессимизм, нетерпимость и т.п.), а все процессы, ведущие к единению человека и с окружающей его социальной и природной средой, ученый характеризует как антропокосмические.

По мнению ученого, «в антропокосмическом отношении к природе самое характерное - это постоянное ощущение человеком своей органической, неразрывной и действенной связи с ней, со всем космосом. Эта связь распространяется на все стороны человеческого существа и имеет двусторонний характер в том смысле, что человек испытывает разнообразные и сложные воздействия со стороны окружающей природы, и сам в то же время может влиять и влияет на нее различными способами» [7. 198] .

Ученые - космисты убеждены в том, что достижение гармонии в системе «общество-природа» связано с разумом человека. В творчестве философов-космистов человек предстаёт как мыслящая, активная, творческая, преобразующая часть Мира. Мировой порядок, имманентный Космосу, включает человека как участника этого самоорганизующегося порядка.

В соответствии с концепцией антропокосмизма необходимо восстановление естественных гармоничных взаимоотношений человека с природой в космопланетарном масштабе. Человек в философии космизма рассматривается как существо далеко несовершенное, но вместе с тем сознательно-творческое, призванное преобразовывать не только внешний мир, но и собственную природу.

По мнению Л.В. Суслова, русский космизм представляет собой «уникальный тип мировосприятия, выражающийся идеей всеединства всего сущего со Вселенной, гармонией человека и Космоса, а также необходимостью продолжения продуктивных функций сознания в целях достижения бессмертия человека и человечества» $[6,4]$.

Идеал представителей философии космизма состоит в гармоничной связи человека с природой Земли и Космоса. Условием реализации избранного ими идеала является единение человечества в планетарную общность. Представители русского космизма рассматривали человечество в контексте всеединства мира. В соответствии с их воззрениями, единому миру должно соответствовать единое планетное человечество, объединенное сознанием и философией общего дела. Для В.С. Соловьева, человечество как единое существо, было осуществлением заложенного в человеке стремления к соборности. Соборность основывается на процессе культурного синтеза, схождения культур, взаимопрорастания их друг в друга на основе общих проблем и целей человечества, общей его судьбы. Согласно Соловьёву, соборность предполагает слияние индивидуального и социального. Это - то общее, которое включает в себя богатство особенного и единичного. Соборность противостоит индивидуально-эгоистическому, это духовное единство, объемлющее весь человеческий род. Соборность представляет собой ту высокую цель, к которой необходимо идти всему человечеству

Таким образом, философия космизма открывает новые мировоззренческие горизонты. Методологической основой формирования онтологической составляющей глобально-ориентированного мировоззрения личности способны служить глобальные идеи философии космизма: идея всеединства, космопланетарного единства Мира, антропокосмизма, глобального эволюционизма.

Опора на рассмотренные идеи как на методологическое основание формирования онтологической составляющей глобально-ориентированного мировоззрения личности обусловливает необходимость осуществления отбора содержания образования с позиций складывающейся в настоящее время системной научно-философской картины мира, в которой Мир исследуется как интегральная материя, как Система Систем. Система категориального аппарата этой картины мира представляет собой своеобразную «матрицу», отражающую целостность мира и служащую инвариантным ядром глобально-ориентированного мировоззрения личности. Системная научно-философская картина мира отражает онтологическую целостность всего сущего. Она раскрывает 
всеобщий синтез объектов и явлений мировой субстанции, выявляет её универсальные характеристики, представляет собой универсальную модель Мира. Отбор содержания образования на основе этой модели Мира нацелен на представление о единстве Мира как Метасистемы. Усвоение учащимися этого содержания образования обеспечивает понимание Мира как Системы-Систем - органичной взаимосвязи и взаимозависимости в рамках единого целого неорганической природы Космоса, неорганической природы планеты Земля, социума и культуры.

Системную научно-философскую картину мира как основу отбора содержания образования, дополняют и конкретизируют естественнонаучная и гуманитарная, экологическая и эстетическая картины мира.

Обновление содержания образования с целью формирования онтологической составляющей глобально-ориентированного мировоззрения личности на основе современных картин мира предполагает акцентирование внимания на следующих блоках знаний:

- о Мире как Метасистеме;

- о глобальной эволюции;

- о человеке как космопланетарном, биосоциальном, социокультурном существе;

- о единстве всех уровней и форм бытия.

$$
* * *
$$

1. Авдеева Е.А. Антропо-онтологический аспект современного образования) / Гуманизация образования №5, 2011 C. 7-16

2. Вернадский В.И. Избранные сочинения: в 5-ти Т. -М.: АН СССР, 1954-1960 т. V

3. Гараева Г.Ф. Софийный идеализм как историко-философский феномен. - М.: Диалог-МГУ. 2000

4. Пастухов А.Л. Глобализация в мировоззрении человека (онтогносеологический аспект). Автореф. дис. ...канд филос. наук. Челябинск, 2005.

5. Пушная М.П. Развитие глобально-ориентированного мышления учащихся старшей школы в условиях интеграции основного и дополнительного образования. Реф. дисс к.П.н. Санкт-Петербург 2004.

6. Суслов Л.В. Нравственные основания русского космизма. Автореф. дис. ... канд. филос. наук. - М., 1999.

7. Холодный Н.Г. Избр. труды. - Киев: Наук. думка, 1982

8. Ц Циолковский К.Э. Воля Вселенной // Грёзы о земле и небе: Научно-фантастические произведения. Тула: Приок. кн. изд-во, 1986. 


\title{
РАЗДЕЛ VІІ. ЭКОНОМИКА
}

\author{
Васильев Ю.Н., Ходус Н.А. \\ Характеристики нормативно-правовой базы в сфере государственных и \\ муниципальных закупок как фактора макросреды организации
}

Санкт-Петербургский Горный университет (Россия, Санкт-Петербург)

doi: $10.18411 / \mathrm{sr}-10-10-2017-12$

idsp: 000001:sr-10-10-2017-12

\section{Аннотация}

Статья посвящена рассмотрению показателей анализа макросреды организации. Основное внимание уделено политическому фактору макросреды, в частности, анализу нормативно-правовой базы в сфере закупок для государственных и муниципальных нужд. Предложены количественные показатели анализа, произведен расчет предложенных показателей и дана характеристика нормативно-правовой базы в сфере закупок для государственных и муниципальных нужд.

Ключевые слова: государственный заказ; закупки; динамизм; макросреда; маркетинг

В теории менеджмента и маркетинга выделяется ряд факторов внешней среды, влияющих на организацию и определяющих принятие ею оперативных и стратегических решений. Так, внешняя среда организации складывается из микро- и макросреды, которые представлены рядом факторов (микросреда: поставщики, потребители, посредники, конкуренты, контактные аудитории; макросреда: природные, демографические, экономические, научно-технические, экологические, политические, культурные).

Макросреда организации характеризуется следующими показателями:

- динамизм (наличие и темпы изменений элементов среды);

- неопределенность (наличие или отсутствие информации о факторах среды);

- сложность (многообразие и взаимосвязь элементов).

Современные условия деятельности организации характеризуются повышенным уровнем динамизма, сложности и неопределенности. Динамизм характеризуется в первую очередь повышенным уровнем изменчивости условий внешней среды и проявляется в высокой частоте преобразований и смены направления движения. Выделяют различные варианты ситуации с точки зрения стабильности и определенности внешней среды: стабильность и определенность; нестабильность и неопределенность; нестабильность и определенность; стабильность и неопределенность [9, с.74].

Анализ макросреды организации осуществляется с применением ряда методов, таких как PEST-анализ, SWOT-анализ, анализ конкурентной среды, маркетинговые исследования и т.п.

При рассмотрении научных трудов, посвященных вопросам анализа внешней среды организаций различных отраслей $[1,5,6,7,8,9,10,12]$ нами выявлено, что для такого анализа используются в основном качественные показатели (менталитет, уровень образования, прогрессивные технологии, государственная политика, уровень культуры и т.п.). Количественные показатели используются для анализа демографических (численность населения, возраст, доля населения в трудоспособном возрасте и т.п.) и экономических (величина доходов, прожиточного минимума, объем спроса, уровень инфляции и т.п.) факторов На наш взгляд, анализ внешней среды организации должен включать определение количественных показателей и по другим факторам макросреды организации. 
Целями данной статьи являются:

- исследование характеристик правового фактора макросреды организации;

- разработка количественных показателей анализа нормативно-правовой базы в сфере закупок для государственных и муниципальных нужд;

- анализ нормативно-правовой базы в сфере закупок с использованием предложенных показателей.

Объектом исследования является сфера закупок товаров, работ, услуг для государственных и муниципальных нужд.

Предмет исследования - нормативно-правовая база, регламентирующая сферу закупок товаров, работ, услуг для государственных и муниципальных нужд.

На наш взгляд, макросреда государственной организации характеризуется относительно невысоким уровнем динамизма, сложности и неопределенности в сравнении с коммерческой организацией. Однако следует отметить, что нормативноправовой базе как элементу политического фактора государственной организации присущ высокий уровень динамики.

Одним из целевых сегментов рынка ряда организаций является рынок государственных учреждений, обладающий определенной спецификой. При планировании своей сбытовой стратегии с ориентацией на рынок государственных учреждений предприятие должно учитывать ряд факторов, оказывающих влияние на эффективность работы на данном рынке (специфика процедуры выбора поставщика, временные ограничения, неизменность цены контракта и т.п.) [3, 4].

Таким образом, можно выделить две группы организаций, для которых нормативно-правовая база является важным фактором макросреды:

- государственная (муниципальная) организация;

- организация, являющаяся поставщиком товаров (работ, услуг) для указанной организации.

Ранее нами отмечалось, что Российская Федерация находится на этапе развития конкурсной системы государственного заказа, который начался с 1 января 2006 г. с принятием Федерального Закона «О размещении заказов на поставки товаров, выполнение работ, оказание услуг для государственных и муниципальных нужд» от 21 июля 2005 г. № 94-Ф3 [2]. Однако в настоящее время необходимо констатировать, что с 01.01.2014 г. начался новый этап - этап развития информационной системы закупок. Данный этап характеризуется в первую очередь тенденциями к полному переходу на электронную форму организации процесса закупок.

Основным нормативно-правовым актом (далее - НПА) в сфере государственных закупок является Федеральный Закон «О контрактной системе в сфере закупок товаров, работ, услуг для обеспечения государственных и муниципальных нужд» от 5 апреля 2013 г. № 44-Ф3 (Далее - Федеральный Закон №44-Ф3). В дополнение к данному закону Правительством Российской Федерации и иными органами принято более 120-ти нормативных документов, регламентирующих различные аспекты организации закупок (планирование, организация отдельных процедур закупок, заключение и исполнение контракта и т.п.).

Для характеристики нормативно-правовой базы предлагается использовать ряд количественных показателей. Показатели динамизма нормативно-правовой базы, представлены табл. 1.

Таблица 1

Показатели динамизма нормативно-правовой базы в сфере государственных (мунииипальных) закупок

\begin{tabular}{|c|c|c|c|}
\hline Показатели & \multicolumn{3}{|c|}{ Степень динамизма } \\
\cline { 2 - 4 } & низкая & средняя & высокая \\
\hline Число НПА, принятых в течение года & $<10$ & $10-12$ & $\geq 12$ \\
\hline Среднее число изменений, внесенных в один НПА за год & $<0,5$ & $0,5-1$ & $\geq 1$ \\
\hline
\end{tabular}


Сложность нормативно-правовой базы может быть выражена общим числом НПА, a также долей постоянно применяемых НПА для регламентации деятельности организации. Неопределенность нормативно-правовой базы может быть выражена количественно в виде наличия и числа проектов НПА в сфере государственных и муниципальных закупок, которые находятся в стадии принятия. Нужно отметить сложность точного определения последнего показателя.

Данные, характеризующие динамизм нормативно-правовой базы в сфере государственных и муниципальных закупок, представлены в табл. 2.

Таблица 2

Данные об изменениях нормативно-правовых актов в сфере государственных (муниципальных) закупок

\begin{tabular}{|c|c|c|}
\hline Год & $\begin{array}{c}\text { Число принятых нормативно-правовых } \\
\text { актов }\end{array}$ & $\begin{array}{c}\text { Число изменений в нормативно- } \\
\text { правовые акты }\end{array}$ \\
\hline 2013 & 32 & 4 \\
\hline 2014 & 30 & 33 \\
\hline 2015 & 46 & 32 \\
\hline 2016 & 19 & 36 \\
\hline итого & 126 & 106 \\
\hline
\end{tabular}

Подсчет числовых показателей, представленных в табл. 2, осуществлялся с использованием материалов официального сайта Института государственных и регламентированных закупок, конкурентной политики и антикоррупционных технологий (http://roszakupki.ru).

Как показывают представленные данные, за последние 4 года в среднем за год принималось 31,5 НПА. Среднее число изменений, вносимых в один НПА за последние годы, составляет 0,84 . Таким образом, степень динамизма нормативно-правовой базы в сфере государственных и муниципальных закупок можно охарактеризовать как высокую.

О сложности данной нормативно-правовой базы свидетельствует число НПА (более 120), а также то, что большинство из них постоянно применяется для организации текущей деятельности как государственной (муниципальной) организации, так и организации-поставщика товаров (работ, услуг).

Кроме того, следует принимать во внимание нередко возникающую проблему сложности формулировок в указанных нормативно-правовых актах. Характеристика данного аспекта описывается исследователями следующим образом: "... заказчик ... не может просто прочитать и применить норму так, как она написана. Он должен прибегнуть к толкованию телеологическому, т.е. к выяснению истинной цели нормотворцев, и систематическому, т.е. к уяснению смысла нормы в контексте иных норм права" [11, с. $15]$.

Также можно сделать вывод о достаточно низкой степени неопределенности (наличие большого массива НПА, наличие ряда проектов НПА, находящихся на стадии принятия).

Таким образом, нормативно-правовая база в сфере государственных и муниципальных закупок может быть охарактеризована как сложная, обладающая высокой степенью динамизма, но при этом достаточно низкой степенью неопределенности.

$$
* * *
$$

1. Анфимов И.А., Муждабаев Ю.Э. Оценка влияния факторов внешней среды на эффективную деятельность организации // Современные технологии в мировом научном пространстве: сборник статей Международной научно практической конференции (25 мая 2017 г., г. Пермь). В 6 ч. Ч.1. Уфа: АЭТЕРНА, 2017. С 38-41

2. Афанасьева Н.В., Васильев Ю.Н. Эволюция подходов к исследованию сферы государственного заказа в Российской Федерации // Вестник Российской академии естественных наук, СПб: ГИЭФПиТ, 2011. №15(4). С. 7-13 
3. Васильев Ю.Н. Маркетинг. Структура комплекса маркетинга: Учеб. пособие / Ю.Н.Васильев. СПб: Санкт-Петербургский государственный горный институт им. Г.В. Плеханова, 2008. 81 с.

4. Васильев Ю.Н., Назарова О.В. Маркетинг. Учебное пособие. СПб: Издательство ФГАОУВО СанктПетербургского политехнического университета Петра Великого, 2015. 106 с.

5. Вдовина О.А., Киреева Е.В. Теоретические подходы к изучению внешней среды организации // Вектор экономики, Пенза: ИП Мухин М.Н., 2017. № 6(12)

6. Гимбатов Ш.М. Демографический фактор как макросреда маркетинга в регионах Северного Кавказа // Вопросы структуризации экономики, Махачкала: Научно-аналитический центр "Этноэкономика", 2012. №1. C. 102-104

7. Магомедалиева О.В., Плоцкий А.К. Макросреда и конкурентоспособность организации // Новые подходы и технологии эффективного управления в глобальной экономике / материалы XI международной научно-практической конференции (25 - 26 октября 2016 г., Орел). Орел: ФГБОУ ВО «ОГУ имени И.С. Тургенева», 2016. С. 241-243.

8. Милкина Е.А. Анализ факторов внешней рыночной среды при планировании стратегии развития предприятия фитнес-индустрии // проблемы экономики современных промышленных комплексов. Финансирование и кредитование в экономике России. Сборник научных статей XI Всероссийской научно-практической конференции. под ред. Д.А. Новикова. 2016. С. 53-60.

9. Мохаммад Н.И., Борис О.А. Нестабильность макросреды и ее влияние на сбалансированность развития хозяйствующих систем // Вестник Северо Кавказского федерального университета, Ставрополь. 2016. № 6(57). C. 73-81

10. Полянских Т.А. Маркетинговая среда высшего профессионального образовательного учреждения // Вестник Евразийской академии административных наук. Волгоград: Волгоградский институт экономики, социологии и права, 2011. №3. С. 131-141

11. Федоров А.А. Проблема познания // Вестник института госзакупок. М.: Центр организации образовательной деятельности Института госзакупок, 2017. № 9(37). С. 15

12. Штезель А.Ю., Штезель А.Э. Микро- и макросреда отечественного банковского маркетинга // Наука 2015: итоги, перспективы: материалы Международной научно-практической конференции (Москва, 25 января 2016 г.). Москва: Грифон, 2016. С. 152-157

\section{Лайпанова 3.М., Боташева А.И. Внутренний контроль : понятие и основные элементы}

СКГГТА

(Россия, Черкесск)

doi: $10.18411 /$ sr-10-10-2017-13

idsp: 000001:sr-10-10-2017-13

Внутренний контроль - процесс, направленный на получение достаточной уверенности в том, что экономический субъект обеспечивает:

- эффективность и результативность своей деятельности, в том числе достижение финансовых и операционных показателей, сохранность активов;

- д достоверность и своевременность бухгалтерской (финансовой) отчетности;

- соблюдение применяемого законодательства, в том числе при совершении фактов хозяйственной жизни и ведении бухгалтерского учета.

Внутренний контроль способствует достижению экономическим субъектом целей своей деятельности. Здесь интересно то, что финансисты говорят об ограничениях эффективности внутреннего контроля, притом что внутренний контроль не гарантирует достижения поставленных целей. Эффективность внутреннего контроля может быть ограничена:

- изменением экономической конъюнктуры или законодательства, возникновением новых обстоятельств вне сферы влияния руководства экономического субъекта;

- превышением должностных полномочий руководством или персоналом экономического субъекта, включая сговор персонала; 
- возникновением ошибок в процессе принятия решений, осуществления фактов хозяйственной жизни, ведения бухгалтерского учета, в том числе составления бухгалтерской (финансовой) отчетности.

С данными ограничениями можно только согласиться: наше законодательство меняется непрерывно, ситуация на рынке также меняется (и не всегда в лучшую сторону), а от ошибок не застрахован никто, при этом нельзя исключать и криминальную составляющую.

Согласно основными элементами внутреннего контроля экономического субъекта являются

- контрольная среда;

- оценка рисков;

- процедуры внутреннего контроля;

- информация и коммуникация;

- оценка внутреннего контроля.

Контрольная среда - это документы, на основании которых в том числе осуществляется внутренний контроль. Это могут быть положение о стратегии, целях и ценностях экономического субъекта, организационная структура экономического субъекта, уровни принятия решений, штатное расписание, внутренние распорядительные документы и др.

Оценка рисков. Вся деятельность экономического субъекта связана с рисками. Работа с рисками является сложной и трудоемкой. Ее условно можно разбить на два этапа: выявление рисков и управление ими. При этом риски оцениваются, и по результатам такой оценки экономический субъект определяет наиболее существенные риски и принимает решения по минимизации их последствий посредством организации и осуществления внутреннего контроля.

Работа с рисками напрямую зависит от бизнес-процессов и процедур работы экономического субъекта. Полноценно такую работу под силу проделать только достаточно крупным структурам. В Рекомендациях даны основные направления по работе с рисками.

Процедуры внутреннего контроля. Такие процедуры нужны для минимизации рисков. Исходя из этого приведены следующие процедуры внутреннего контроля (с примерами):

- документальное оформление: записи в регистрах бухгалтерского учета должны осуществляться на основе первичных учетных документов, бухгалтерских справок, расчетов;

- подтверждение соответствия между объектами (документами) или их соответствия установленным требованиям: при принятии первичных учетных документов к бухгалтерскому учету должна производиться проверка их оформления на соответствие требованиям законодательства;

- санкционирование (авторизация) хозяйственных операций, которое подтверждает правомочность совершения операций: авансовый отчет сотрудника должен быть утвержден руководителем или санкционирование (авторизация) платежей может осуществляться руководителями разного уровня в зависимости от суммы платежа;

- сверка данных: должна производиться сверка расчетов с поставщиками и покупателями;

- разграничение полномочий и ротация обязанностей: полномочия по подготовке первичных учетных документов, санкционированию (авторизации) хозяйственных операций и отражению результатов хозяйственных операций в бухгалтерском учете должны возлагаться на разных лиц на ограниченный период; 
- физический контроль: должны обеспечиваться охрана объектов, ограничение доступа к ним, их инвентаризация;

- надзор: должна осуществляться оценка правильности выполнения хозяйственных и учетных операций, соблюдения установленных сроков составления бухгалтерской (финансовой) отчетности;

- процедуры, связанные с компьютерной обработкой информации и информационными системами (правила и процедуры, регламентирующие доступ к информационным системам, правила внедрения и поддержки информационных систем, процедуры восстановления данных и другие процедуры, обеспечивающие бесперебойное использование информационных систем).

Процедуры внутреннего контроля делятся:

- в зависимости от момента осуществления - на предварительные и последующие;

- в зависимости от степени автоматизации - на автоматические, полуавтоматические и ручные.

Информация и коммуникация. Качественная и своевременная информация обеспечивает функционирование внутреннего контроля и возможность достижения поставленных целей. Качество хранимой и обрабатываемой информации может существенно влиять на управленческие решения экономического субъекта, эффективность внутреннего контроля. Вне зависимости от того, подлежит ли бухгалтерская (финансовая) отчетность экономического субъекта аудиту, информационная система экономического субъекта должна обеспечивать ведение бухгалтерского учета, в том числе составление бухгалтерской (финансовой) отчетности.

Оценка внутреннего контроля. Минфин рекомендует проводить оценку внутреннего контроля не реже одного раза в год. Ее целью является определение эффективности внутреннего контроля.

Результаты оценки внутреннего контроля должны быть оформлены документально, согласованы с исполнителями процедур внутреннего контроля и представлены руководству экономического субъекта. Объем, состав и формы документации определяются потребностями экономического субъекта.

В случае выявления недостатков эффективности внутреннего контроля анализируются их причины. Составляется план устранения недостатков с указанием сроков.

Лайпанова 3.М., Лайпанова Н.У.

Себестоимость. Понятие, виды и элементы

СКГГТА

(Россия, Черкесск)

doi: $10.18411 / \mathrm{sr}-10-10-2017-14$

idsp: 000001:sr-10-10-2017-14

Одним из важных участков управленческого учета на производственных предприятиях является учет затрат на производство продукции и определение ее себестоимости.

Себестоимость продукции - емкая, многообразная и динамичная экономическая категория. Она является важнейшим качественным показателем, показывая, во что обходится предприятию производство и сбыт продукции. Чем ниже себестоимость, тем выше прибыль и, соответственно, рентабельность производства.

Исчисление себестоимости продукции предприятию необходимо для оценки выполнения плана по данному показателю и его динамики; определения рентабельности 
производства и отдельных видов продукции; осуществления внутрипроизводственного хозрасчета; выявления резервов снижения себестоимости продукции; определения цен на продукцию; расчета экономической эффективности внедрения новой техники, технологии, организационно-технических мероприятий; обоснования решения о производстве новых видов продукции и снятия с производства устаревших изделий и т.д.

Себестоимость продукции включает различные виды затрат, зависящих и не зависящих от работы предприятия, вытекающих из характера данного производства и не связанных с ним непосредственно. В связи с этим важное значение имеет четкое определение состава затрат, которые ее формируют.

Одним из основных условий получения достоверной информации о себестоимости продукции является научно обоснованная классификация затрат, включаемых в ее состав.

На практике затраты предприятия традиционно группируются и учитываются по составу и видам, местам возникновения и носителям.

По составу затраты подразделяются на одноэлементные и комплексные.

Одноэлементными называются затраты, состоящие из одного элемента, материалы, заработная плата, амортизация и др. Эти затраты независимо от их места возникновения и целевого назначения не делятся на различные компоненты.

Комплексными называются затраты, состоящие из нескольких элементов, например, цеховые и общезаводские расходы, в состав которых входит заработная плата соответствующего персонала, амортизация зданий и другие одноэлементные затраты.

Учет по видам затрат классифицирует и оценивает ресурсы, использованные в процессе производства и реализации продукции. По данному признаку затраты классифицируют по статьям калькуляции и экономическим элементам.

Состав затрат, включаемых в себестоимость продукции, регламентируется соответствующими нормативными актами, прежде всего - «Положением о составе затрат по производству и реализации продукции (работ, услуг), включаемых в себестоимость продукции (работ, услуг), и о порядке формирования финансовых результатов, учитываемых при налогообложении прибыли» (утверждено Постановлением правительства РФ 5 августа 1992 г. №552 с последующими изменениями и дополнениями). Этим же документом установлен единый для всех предприятий перечень экономически однородных элементов затрат:

- материальные затраты;

- затраты на оплату труда;

- отчисления на социальные нужды;

- амортизация основных фондов;

- прочие затраты.

Группировка затрат по экономическим элементам является объектом финансового учета и показывает, что именно израсходовано на производство продукции, каково соотношение отдельных элементов в общей сумме затрат. Данная группировка используется при составлении приложения к балансу (форма №5).

Для исчисления себестоимости отдельных видов продукции производственные предприятия используют группировку затрат по статьям калькуляции. Номенклатуру статей каждое предприятие может устанавливать для себя самостоятельно с учетом своих специфических потребностей. Их примерный перечень установлен отраслевыми инструкциями по учету и калькулированию себестоимости продукции. В наиболее общем виде номенклатура статей калькуляции выглядит следующим образом:

1. «Сырье и основные материалы»;

2. «Полуфабрикаты собственного производства»;

3. «Возвратные отходы» (вычитаются);

4. «Вспомогательные материалы»;

5. «Топливо и энергия на технологические цели»;

6. «Расходы на оплату труда производственных рабочих»; 
7. «Отчисления на социальные нужды»;

8. «Расходы на подготовку и освоение производства»;

9. «Расходы по эксплуатации производственных машин и оборудования»;

10. «Цеховые расходы»;

11. «Общехозяйственные расходы»;

12. «Потери от брака»;

13. «Прочие производственные расходы»;

14. «Коммерческие расходы».

Итог первых тринадцати статей образует производственную себестоимость, а итог всех четырнадцати статей - полную себестоимость продукции.

По месту возникновения затраты группируются и учитываются по производствам, цехам, участкам, отделам и другим структурным подразделениям предприятия, т.е. по центрам ответственности. Такая группировка затрат позволяет организовать внутренний хозрасчет и определить производственную себестоимость продукции. Учет по центрам ответственности «привязывает» учет затрат к организационной структуре предприятия или организации.

Завершающим этапом является группировка и учет по носителям затрат, т.е. продукции, работам, услугам с целью определения их себестоимости.

\section{Пучкунова Е.С., Ясменко Г.Н. \\ Сложности в определении понятия «достоверность» применительно к бухгалтерской (финансовой) отчетности}

Кубанский государственный аграрный университет имени И. Т. Трубилина (Россия, Краснодар)

doi: $10.18411 / \mathrm{sr}-10-10-2017-15$

idsp: 000001:sr-10-10-2017-15

\section{Аннотация}

В статье рассматривается актуальные вопросы достоверности учетной и отчетной информации, раскрываются понятия, связанные с искажениями информации в бухгалтерском учете и бухгалтерской (финансовой отчетности). Исследование различных трактовок термина «достоверности бухгалтерской (финансовой) отчетности позволило выявить отсутствие прямого определения данного понятия в российских нормативных документах. Установлено, что только вероятностно-качественная оценка существенности обеспечит содержательную достоверность бухгалтерской отчетности, а не только формальную.

Ключевые слова: Искажения бухгалтерской (финансовой) отчетности, существенные искажения, несущественные искажения, достоверность бухгалтерской (финансовой) отчетности, учетная и отчетная информация.

Одним из основных требований к бухгалтерской (финансовой) отчетности, выдвигаемых заинтересованными пользователями, является ее соответствие критерию достоверности. Что означает это понятие, какую бухгалтерскую отчетность можно признать достоверной, и как бухгалтер может установить, является ли достоверной отчетность его организации?

Согласно российскимучетным стандартам достовернойсчитается бухгалтерская (финансовая) отчетность, которая сформирована в соответствии с нормативными требованиями. В то же самое время, следует отметить, что даже полное соблюдение учетных и отчетных регламентов не гарантирует «достоверности» отчетной информации с позиций различных категорий пользователей. Исходя это этого, сам по себе термин «достоверность» относителен. Поскольку круг пользователей отчетности многообразен и широк, затруднительно одновременно удовлетворить все их интересы. Для одной группы 
пользователей существует один критерий достоверности отчетной информации, а для другой - совсем иной. На относительность отчетных данных еще в 20-е годы прошлого века указывал автор научной теории бухгалтерского учета А.П. Рудановский.

Российский ученый-экономист Я.В. Соколов также считал, что учетная (и, соответственно, отчетная) информация в принципе не может быть достоверной, прежде всего в силу ее историчности. Обращаясь к понятию «достоверность», Я. В. Соколов указывал на наличие в нем не абсолютной истины, подразумевающей абсолютную точность, а истины относительной. По мнению ученого, речь должна идти скорее о точности учетной информации, позволяющей сформировать мнение и оставаться достаточной для принятия управленческих решений.

Если обратиться к международной учетной теории и практике, то в разных странах достоверность бухгалтерской (финансовой) отчетности определяется по-разному. Так, в Великобритании она связана с концепцией «достоверный и добросовестный взгляд», которая закреплена в законодательных актах и связана с аудиторским заключением. Согласно этому подходу организация должна отклониться от принятых нормативных требований, если они не позволяют точно и объективно представить имущественное положение в отчетности. Схожий подход в определении достоверности обозначен в МСФО 1 (IAS) «Представление финансовой отчетности» и П. 6 ПБУ 4/99 «Бухгалтерская отчетность организации».

Конечно, правила, регламентирующие бухгалтерский учет, в российских учетных стандартах и МСФО очень схожи, но всеже международные стандарты предоставляют больше свободы при классификации и оценке различных фактов хозяйственной жизни.В данной ситуации можно выявить своеобразный парадокс: международные стандарты не устанавливают жестких ограничений при отражении разнообразных фактов хозяйственной жизни, однако при таком подходе достоверность бухгалтерской (финансовой) отчетности обеспечивается в большей мере.

Таким образом, целесообразно достоверность рассматривать с двух позиций: достоверность - как неукоснительное следование требованиям нормативных актов (достоверность формальная), и достоверность - как характеристика информации, которая отражает истинное финансовое положение и результаты деятельности организации (достоверность содержательная).

В свою очередь, обе обозначенные трактовки достоверности определяют «качественные» характеристики бухгалтерской (финансовой) отчетности, но не содержат в себе указания стартовой точки «качества», то есть обозначения условий, при которых будет считаться, что отчетность не удовлетворяет ни формальному, ни содержательному критерию достоверности.

Если считатьстартовой точкой «качества» отчетности отсутствие в ней ошибок и учитывать степень относительности понятия «достоверность» для различных категорий пользователей можно указать, что достоверной (с учетом формального и содержательного критерия) целесообразно признавать бухгалтерскую (финансовую) отчетность с предельно допустимым уровнем искажений. Данный уровень, в свою очередь, не может быть самостоятельно оценен большинством заинтересованных пользователей из-за ограниченности доступа к учетной и прочей информации, а также многочисленности и сложности фактов хозяйственнойжизни, отражаемых в бухгалтерской отчетности экономических субъектов. Помимо этого, бухгалтерская (финансовая) отчетность может быть подвержена искажениям в силу применения оценочных значений в бухгалтерском учете, возможной пристрастности ее составителей. Отсюда возникает необходимость подтверждения достоверности бухгалтерской (финансовой) отчетности и установления для нее предельного уровня искажений.

В сфере императивных регламентов, имеющих прямое отношение к идентификации искажений и ошибок в учете и отчетности, действуют несколько документов, а именно: ПБУ 22/2010 «Исправление ошибок в бухгалтерском учете и 
отчетности», ФСАД 5/2010 «Обязанности аудитора по рассмотрению недобросовестных действий в ходе аудита», МСА 240 «Обязанности аудиторов в отношении недобросовестных действий при проведении аудита финансовой отчетности», а при составлении консолидированной отчетности - МСФО 8 «Учетная политика, изменения в бухгалтерских оценках и ошибки».

Современные требования учетных стандартов устанавливают в качестве пограничного между недостоверной и достоверной бухгалтерской (финансовой) отчетностью уровень существенности ошибки (искажений) в ней. При этом под существенной ошибкой понимается такая ошибка (совокупность ошибок), которая обусловлена отступлением от гражданско-правовых, бухгалтерских, налоговых и иных законодательных предписаний, и регламентов и которая влечет за собой существенные риски не только для инвесторов, кредиторов, заемщиков, других пользователей отчетности, но и для самих экономических субъектов, утрачивающих доверие на рынке товаров, работ, услуг и капиталов. В отдельных случаях искажение бухгалтерской (финансовой) отчетности может быть признано существенным, даже если ошибка сама по себе существенной не является. Несущественная ошибка может быть квалифицирована в существенную, если она вызывает неточности в учете, которые распространяются по цепочке на многие показатели бухгалтерской (финансовой) отчетности. Например, неправильное отражение сальдо по счетам денежных средств и дебиторской задолженности воздействует только на эти счета и не влияет на отчетные показатели. Напротив, ошибка при учете объемов продаж уже является «носителем» неточности в отчетные формы, поскольку влияет не только на собственно объем реализации, но и на сальдо дебиторов, балансовую и чистую прибыль, сумму налоговых платежей, реинвестированную прибыль, и поэтому такая ошибка является существенной.

Таким образом, следует заключить, что понятие достоверности бухгалтерской (финансовой) отчетности является довольно многогранным, отсутствие четко обозначенных критериев признания достоверности порождает существенное число злоупотреблений при подготовке и представлении отчетности. Усугубляет ситуацию еще и отсутствиеединых формулировок в нормативно-правовых актах относительно категории «достоверность», что вызывает сложности с единообразным пониманием требований юридических норм. А единообразие подходов в данной ситуации имеет больше значение, так как за неисполнение нормативных положений возможно применение соответствующих санкций (ст. 15.11 КоАП).

$$
* * *
$$

1. Левченко Е.В. Достоверность финансовой отчетности / Е.В. Левченко, Д.М. Кагазежева // Формирование экономического потенциала субъектов хозяйственной деятельности: проблемы, перспективы, учетно-аналитическое обеспечение: материалы VI Международной научной конференции. ФГБОУ ВПО «Кубанский государственный аграрный университет». 2016. С. 9-13.

2. Левченко Е.В. Реформирование бухгалтерского учета в России в соответствии с международными стандартами / Е.В. Левченко, Г.Н. Ясменко, А.Ю. Крючкова // Формирование экономического потенциала субъектов хозяйственной деятельности: проблемы, перспективы, учетно-аналитическое обеспечение: материалы VI Международной научной конференции. ФГБОУ ВПО «Кубанский государственный аграрный университет». 2016. С. 182-186.

3. EreminaN.V. A FIRM'S COMPETITIVENESS AND WAYS OF ITS INCREASE / N.V. Eremina, E.V. Levchenko, K.V. Buzun, Y.S. Varivoda//Проблемы экономики, организации и управления в России и мире: материалы XIII международной научно-практической конференции. Ответственный редактор Н.В. Уварина. 2017. С. 88-90.

4. Положение по бухгалтерскому учету (ПБУ 22/2010) "Исправление ошибок в бухгалтерском учете и отчетности", утв. Приказом Минфина России от 28 июня 2010 г. N 63н.

5. МСФО (IAS) 8 «Учетная политика, изменения в бухгалтерских оценках и ошибки» [Электронный ресурс]. Режим доступа: СПС КонсультантПлюс. 


\title{
РАЗДЕЛ VIII. МЕНЕДЖМЕНТ
}

\author{
Белевич Н.А. ${ }^{1}$, Ткачёва Г.А. ${ }^{2}$ \\ Особенности мотивации и стимулирования труда работников здравоохранения \\ ${ }^{1}$ Российская академии народного хозяйства и государственной службы при \\ Президенте Российской Федераџии \\ ${ }^{2}$ Санкт-Петербургское государственное бюджетное учреждение здравоохранения \\ «Городская больница № 28 \\ (Россия, Санкт-Петербург)
}

doi: $10.18411 / \mathrm{sr}-10-10-2017-16$

idsp: 000001:sr-10-10-2017-16

На сегодняшний день проблема повышения трудовой мотивации сотрудников медицинских учреждений является очень важной функцией управления здравоохранением. Главной целью процесса трудовой мотивации в здравоохранении является получение максимального эффекта от использования имеющихся ресурсов, позволяющих увеличить общую результативность деятельности организации.

Современная модель мотивации труда в здравоохранении во многом впитала в себя элементы советской модели стимулирования труда. Однако с возникновением рыночных отношений в стране повлияло на изменения в системе человеческих ценностей: большинство медработников уверены в том, что для безбедной жизни важны должность (особый статус), связи с нужными людьми, работа в рыночном секторе экономики.

Особая специфика труда медицинского работника связана, в первую очередь, с большим объемом информации, высокой степенью ответственности, выраженным психоэмоциональным напряжением и соответственно этому требуется эквивалентное денежное вознаграждение.

Заработная плата является важнейшей частью системы оплаты и стимулирования труда, а также одним из инструментов воздействия на эффективность труда работника в медицинских организациях.

Оплата труда работников учреждений здравоохранения, которые находятся на бюджетном финансировании, выстраивается на единых принципах и состоит из тарифных ставок (окладов), а также выплат компенсационного и стимулирующего характера, предусмотренных действующим законодательством Российской Федерации.

Тарифная ставка (оклад) - это фиксированный размер оплаты труда сотрудника за выполнение нормы труда определенной сложности за единицу рабочего времени. То есть, она учитывает уровень профессионального мастерства, а также квалификацию работника, сложность выполняемых работ. Несмотря на свою прозрачность, тарифная ставка не в состоянии отразить степень напряженности труда каждого конкретного работника, выполнение работ в особых условиях и ряд других факторов. Оплата труда работников здравоохранения должна побуждать персонал к повышению качества оказываемых услуг, а также рациональному использованию имеющихся ресурсов, то есть иметь стимулирующий оттенок. Однако, учитывая сложившийся уровень оплаты труда, о котором мы упомянули ранее, пока что говорить об этом рано.

На сегодняшний момент стоит острая необходимость в разработке таких механизмов, позволяющих связать в едино качество выполнения работ с заинтересованностью ее исполнителей.

Для того, чтобы более детально изучить, что в большей степени мотивирует сотрудников здравоохранения на выполнение работы в бюджетной сфере здравоохранения было проведено исследование на базе ГБУЗ "Городская поликлиника №91 г. Санкт-Петербурга, целью которого было изучить мотивирующие и 
демотивирующие факторы сотрудников. Для достижения поставленной цели были использованы следующие методы исследование: анкетирование, социологический опрос, тестирование по методике Герчикова (определение ведущего типа мотивации). В исследовании приняли участие 30 человек. Изначально проблема мотивации сотрудников представлялась банально недостаточным финансированием, т.е. низкой заработной платой, но т.к. увеличить финансирование в бюджетной сфере задача достаточно сложная, то была сделана попытка обратиться к методам нематериального стимулирования, но для того, чтобы эти действия имели положительный результат и было проведено данное исследование.

В результате было выявлено, что основной костяк коллектива составляют женщины в возрасте от 30 до 50 лет $-70 \%$; до 30 лет - 20\% и старше 50 лет - $10 \%$. Средний стаж работы в учреждении составил около 20 лет. Это свидетельствует о серьезном подходе сотрудников к своей профессии, о достаточной "зрелости" коллектива, о качестве профессионального отбора (что в свою очередь может быть обусловлено достаточно сложным процессом обучения ещё в вузе).

Тестирование по методике Герчикова показало, что в коллективе преобладают сотрудники с профессиональным типом мотивации (50\%). Инструментальный тип мотивации присущ $40 \%$ сотрудников и всего $10 \%$ составили сотрудники с люмпенизированным типом мотивации.

Исходя из полученных результатов, можно сделать некую характеристику персонала:

1. Профессиональный тип мотивации: сотрудников такого типа мотивации больше интересует содержание работы, они часто не соглашаются на менее интересную работу, сколько бы за нее не платили. Кроме того, руководитель должен стараться дать определенную свободу действий в решении оперативных задач. Также такой сотрудник нуждается в профессиональном признании со стороны руководства, а также его коллег.

2. Инструментальный тип мотивации: сотрудников такого типа мотивации больше интересует оплата труда, а не его содержание. С позиции руководителя важно организовать открытость, обоснованность цены за труд.

3. Люмпенизированный тип мотивации: хоть и данный тип мотивации в этом учреждении имеет небольшой процент, необходимо иметь во внимании, что сотрудник с таким типом мотивации, не имеет определенных предпочтений в выполнении тех или иных работ (ему все равно, что делать). Как правило, такие сотрудники имеют низкую квалификацию труда, не стремясь ее повышать. Они не готовы брать на себя ответственность за решение каких-либо вопросов.

В зависимости от типа мотивации будут различны виды стимулирвания и их эффективность. Данное соотношение представлено в таблице 1.

Таблийа 1

Стимулирование работников с разными типами мотиващии

\begin{tabular}{|c|c|}
\hline Тип мотивации & Эффективный вид стимулирования \\
\hline Инструментальный & Преимущественно денежный \\
\hline Профессиональный & Организационные мероприятия \\
\hline Люмпенизированный & Натуральный и негативный \\
\hline
\end{tabular}

Оплата труда таких работников должна строиться на определенных принципах. Так, для сотрудников с профессиональным типом мотивации характерна повременная оплата труда, которая основывается на точной увязке уровня квалификации работника или определенных особенностях его должности. Для сотрудников с инструментальным типом мотивации характерна больше сдельная оплата труда, которая выплачивается по достигнутым результатам работы. Для сотрудников с преобладающим люмпенизированным типом мотивации больше характерна повременная оплата труда с 
зависимостью зарплаты от затрат труда, но, в идеале, от общих показателей работы всего отдела.

Таким образом, зная свой коллектив, то, что реально их движет в работе, руководитель сможет уверенно мотивировать своих сотрудников, иногда, не прибегая к серьезным затратам.

По результатам анкетирования только 4\% сотрудников полностью не удовлетворены оплатой труда, 90\% считают, что их труд мог бы оплачиваться более высоко, но при этом из остальных ответов на вопросы анкеты становится понятно, что медицинский персонал поликлиники понимает, что повлиять на заработную плату не возможно, так как она устанавливается исходя из среднерыночных показателей оплаты труда в соответствии с должностью и в целом готовы принять это обстоятельство. Основные ценности, играющие важное значение в профессиональной и личной жизни сотрудников оказались преимущественно материальная независимость (46\%), самореализация в работе (32\%), оказание помощи (22\%).

Основными демотивирующими факторами в работе оказалась не заработная плата, как предполагалось изначально. Последующий анализ полученных данных показал, что $60 \%$ медицинских работников не удовлетворены организацией труда, $70 \%$ отмечают свое недовольство тем, как их информируют об общем положении дел в организации. 80\% сотрудников считаю, что руководство относится к ним как к инструменту для извлечения прибыли и только $20 \%$ чувствуют обратное.

Для того, чтобы оценить как изученные параметры взаимосвязаны и более четко представлять следственно-логические связи между этими параметрами был проведен корреляционный анализ, результаты которого представлены в таблице 2.

Таблииа 2

Результаты корреляиионного анализа

\begin{tabular}{|c|c|c|c|}
\hline Параметр 1 & Параметр 2 & $\begin{array}{c}\text { Коэффициент } \\
\text { связи }\end{array}$ & $\begin{array}{c}\text { Уровень } \\
\text { значения }\end{array}$ \\
\hline $\begin{array}{c}\text { Удовлетворенность уровнем } \\
\text { 3/пл }\end{array}$ & $\begin{array}{c}\text { Эффективная система обмена } \\
\text { информацией }\end{array}$ & 1 & 0,03 \\
\hline $\begin{array}{c}\text { Удовлетворенность уровнем } \\
\text { з/пл }\end{array}$ & $\begin{array}{c}\text { Удовлетворенность организацией } \\
\text { труда }\end{array}$ & 0,612 & 0,04 \\
\hline $\begin{array}{c}\text { Удовлетворенность уровнем } \\
\text { з/пл }\end{array}$ & $\begin{array}{c}\text { Как часто руководитель информирует } \\
\text { персонал об положении дел в орг. }\end{array}$ & 0,557 & 0,029 \\
\hline $\begin{array}{c}\text { Справедливость з/пл по } \\
\text { отношению к труду }\end{array}$ & Удовлетворенность организацией \\
труда & 0,612 & 0,04 \\
\hline $\begin{array}{c}\text { Справедливость з/пл по } \\
\text { отношению к труду }\end{array}$ & Демократический стиль управления & 0,557 & 0,017 \\
\hline $\begin{array}{c}\text { Жизненные цели: } \\
\text { материальная независимость }\end{array}$ & $\begin{array}{c}\text { Ущемляете ли вы свои личные } \\
\text { интесы ради интересов организации }\end{array}$ & 0,667 & 0,600 \\
\hline $\begin{array}{c}\text { Удовлетворенность } \\
\text { организацией труда }\end{array}$ & $\begin{array}{c}\text { Персол для руководителя - } \\
\text { партнеры }\end{array}$ & 0,032 \\
\hline
\end{tabular}

По результатам корреляционного анализа выявились следующие взаимосвязи:

1. Удовлетворенность заработной платой напрямую связана с удовлетворенностью условиями труда, информированностью персонала о текущем положении дел и стилем управления.

2. Стремление к материальной независимости напрямую связано с готовностью ставить интересы работы выше своих личных.

3. Если руководство видит в персонале партнеров - то как правило сотрудники положительно оценивают условия труда.

Таким образом, нами были выявлены основные проблемы в организации:

1. это неудовлетворенность 3/пл;

2. неудовлетворенность отношением руководства к персоналу, как к инструменту; 
3. неудовлетворенность условиями организации труда.

Это отражается, прежде всего, тем, что персонал свои личные интересы ставит выше профессиональных и не стремятся к развитию в профессии.

Повлиять на уровень заработной платы не представляется возможным, и как показывает теория и практика - это, как правило, не эффективно.

Но, исходя из данных, полученных методом корреляционного анализа, можно с высокой степенью достоверности говорить о том, что изменив условия организации труда, стиль управления и отношение руководство к персоналу, можно будет достичь общей удовлетворенности по перечисленным факторам и как следствие повысить субъективную удовлетворенность заработной платой., так как эти понятия оказались тесно взаимосвязаны.

Барышникова И.А. Анализ системы мотивации и стимулирования труда персонала организации здравоохранения (на материалах ОБУЗ «Офтальмологическая клиническая больница - офтальмологический центр») // Экономика, предпринимательство и право. 2014. — Том 4. — № 2. - c. 39-46. 


\section{РАЗДЕЛ ІХ. ЮРИСПРУДЕНЦИЯ}

\section{Лятычевская Ю.В. \\ Особенности правового регулирования референдума в Российской Федерации}

Северо-Кавказский федеральный университет

(Россия, Ставрополь)

doi: $10.18411 / s r-10-10-2017-17$

idsp: 000001:sr-10-10-2017-17

\section{Аннотация}

В статье анализируются проблемы правового регулирования организации и проведения референдумана современном этапе развития российской государственности, оценивается несовершенство законодательной базы для полноценной реализации избирательных прав граждан.

Ключевые слова: референдум, анализ, конституция,гражданские свободы, законодатель, прямое волеизъявление, ограничения, инициативная группа, политический процесс.

Референдум занимает значительное место в политической и юридической сфере жизни современной России. С одной стороны он дает право гражданам решать важные и значительные проблемы, назревшие в обществе, путем прямого волеизъявления[2], с другой стороны ряд вопросов и периоды проведения сильно ограничены законодателем, что ставит под сомнение целесообразность и прозрачность этой процедуры.

Анализируя историю развития России, сложно не отметить незаслуженное игнорирование института референдума. Только в начале 90 -х годов, власти обратились к этой процедуре прямого волеизъявления, используя его как инструмент в реализации своих политических интересов. Однако этот период продлился недолго, после принятия Конституции РФ 1993 г., референдумы больше не проводились на федеральном уровне, несмотря на неоднократное выдвижение инициатив[3].

Власть понимала, насколько непопулярна и лишена поддержки граждан проводимая социальная политика, и референдум мог стать неуправляемой для нее проблемой, поэтому всеми возможными путями препятствовала дальнейшему его проведению. Это подтверждается неоднократными попытками внесения изменений и поправок в российское законодательство о референдумах. Например, в Федеральном законе от 24 июня 2004 г. «О референдуме Российской Федерации» расширен список параметров, при которых проведение референдума не возможно, что значительно ограничивает гражданские свободы.

Даже учитывая современную политическую обстановку, и значительную поддержку со стороны населения проводимой политики, законодатель предъявляет достаточно жесткие требования к проведению референдума[6].

Во-первых, это ограниченные временные периоды проведения референдума. Так референдум не может назначатьсяв последний год полномочий Президента РФ, Государственной Думы Федерального Собрания РФ, а также в период избирательной кампании, проводимой одновременно на всей территории Российской Федерации. Так же вызывает ряд вопросов, почему нельзя проводить референдум в течение трех месяцев после отмены чрезвычайного положения, когда общественная жизнь уже нормализовалась[1].

Во-вторых, законодателем четко определен ряд вопросов, по которым он не может быть проведен (о сроках полномочий Президента РФ, Государственной Думы РФ, проведении досрочных выборов этих органов либо о перенесении сроков таких выборов, 
по вопросам, отнесенным Конституцией РФ, федеральными конституционными законами к исключительной компетенции федеральных органов государственной власти)[7].

Множество вопросов в научных кругах вызывает процедура инициирования референдума. Так к формированию инициативной группы предъявляются довольно жесткий ряд условий:

- состав группы должен быть не меньше 2 млн. граждан, имеющих право участвовать в референдуме;

- основой для создания инициативной группы являются региональные подгруппы, которые должны быть созданы более чем в половине субъектов Российской Федерации. Состав подгрупп - не менее 100 человек, что иногда является практически невыполнимой задачей в малонаселенных субъектах. Собрания подгруппы должно проводится на территории того региона где зарегистрированы и проживают участники референдума, а подписи в протоколе заседания должны нотариально заверяться.

Инициативной группе необходимо по закону в течение 45 дней, собрать 2 миллиона подписей в поддержку проведения референдума, при этом не разрешается привлекать к этой процедуре посторонних лиц, что значительно осложняет решение поставленной задачи.

В федеральном законе от 24 июня 2004 г. закреплено право граждан на создание агитационной группы, численность которой должно быть не менее 500 человек[4]. При этом участнику инициативной группы запрещено входить в состав агитационной группы, что является нарушением права граждан на объединение (ст.30 Конституции РФ).

Таким образом, мы сталкиваемся с двоякой ситуацией в современном законодательстве о референдуме, с одной стороны необходимы правовые ограничения организации референдума, с другой стороны возникает проблема, что бы эти жесткие рамки не ущемляли реализацию прав граждан и не доводили ситуацию реализацию закона на практике до абсурда [5]. Как же законодателю соблюсти этот баланс? Для этого необходимо соблюдать принципы соразмерности, обоснованности и необходимости этих ограничений, что было указано в постановлении Конституционного Суда РФ от 11 июня 2003 г.

За сравнительно недолгий период участия в политическом процессе Российской Федерации института референдума был получен значительный опыт правового регулирования вопросов его подготовки и проведения[8]. Между тем анализ нормативноправовой базы организации и проведения референдума показывает несовершенство целого ряда нормативных предписаний, нерешенность множества организационноправовых вопросов, недостаточную эффективность использования данной формы принятия решений по политически значимым направлениям.

Bce это показывает острую необходимость дальнейшего обобщения и совершенствования, как теории референдума, так и практики его использования в политическом процессе, что предполагает совершенствование его нормативного регулирования, приведение его в соответствие с требованиями современной демократической российской государственности.

$$
* * *
$$

1. Каденко В.В. Референдум в политическом процессе в России.-Дисс. канд. юр.наук. Ростов-наДону,2009. $150 \mathrm{c}$.

2. Казановская Ю.А. Отражение основных ценностей общества в правосознании индивидов // НаукаПарк. 2014. №1(20). C. 48-53.

3. Климова М.И. Законодательство о референдуме и проблемы реализации непосредственной демократии в Российской Федерации// Вопросы современной юриспруденции: сб. ст. по матер. ХI междунар. науч.практ. конф. Часть II. - Новосибирск: СибАК, 2012.

4. Комарова В. В. Механизм непосредственной демократии современной России (Система и процедуры). M., 2006. C. 103-111. 
5. Лучин В. О., Мазуров А. В. Новый закон о референдуме // Право и политика. 2004. № 8. С. 6.

6. Нудненко Л. А. Законодательство о выборах и референдумах: детализация и совершенствование // Российский юридический журнал. 2009.№ 1.С. 178.

7. Пастухова Н. В. Правовые ограничения инициирования, назначения и проведения референдума в Российской Федерации: понятие и система // Государство и право. 2010. № 10. С. 112, 115.

8. Турищева, Н. Ю. Преступления против избирательных прав и права на участие в референдуме / Н.Ю. Турищева. - М.: Издательство Р. Асланова "Юридический центр Пресс", 2010. - 352 с.

\section{Скопенко О.P. \\ Наследственный фонд: зарубежный опыт и перспектива развития в России}

Белгородский государственный нацииональный исследовательский университет (НИУ «БелГУ»)

(Россия, Белгород)

doi: $10.18411 / \mathrm{sr}-10-10-2017-18$

idsp: 000001:sr-10-10-2017-18

\section{Аннотация}

Статья посвящена нововведениям в российское наследственное законодательство, а именно, введению с 01сентября 2018 года новой формы юридического лица Наследственного фонда. В ней освещены проблемы, связанные с реализацией этого нового инструмента управления бизнесом в случае смерти владельца, создаваемого в исполнении его завещания.

Автор, опираясь на многовековую историю создания и существования частных фондов, как в Америке, так и в странах Европы, сходных по признакам правовой формы, но различных по целям и характеру деятельности, определяет преимущества и недостатки создания и существования Наследственного фонда в России. Дается понятие Наследственного фонда, выделяются основные аспекты положений о новом правовом институте, особенности его формирования и функционирования в России.

Ключевые слова: наследники, завещание, частный фонд, траст, Наследственный фонд, бенефициары.

Институт наследования в Российском праве всегда занимал и продолжает занимать особое место. Если говорить об истоках его возникновения, то это произошло еще несколько тысяч лет назад с появлением частной собственности. Однако все большую актуальность вопросы наследования приобретают в современном мире. И связано это тесным образом с развитием бизнеса.

Если обратиться к современной России, то она существенно отличается от времен СССР социальным расслоением, когда разделение на «богатых и бедных» увеличивается с огромной скоростью. Все больше граждан создают свой успешный бизнес и пытаются управлять им, зарабатывая достаточные капиталы, которые состоят из различных активов. Это и денежные средства в разных валютах, ценные бумаги, недвижимость, корпоративные права участия, интеллектуальная собственность и т.д. В связи с этим возникает логичный вопрос: «Как грамотно распорядиться этим капиталом, чтобы сохранить его и приумножить достигнутое?». Особенно этот вопрос становится актуальным при передаче капитала приемникам. Поэтому главной проблемой российского наследственного права, которую необходимо решить на сегодняшний день, является отсутствие механизма управления бизнесом в случае смерти владельца, если не предусмотрен порядок завещания.

В связи с этим Государственной Думой был принят Федеральный закон от 29.07.2017 № 259-Ф3 «О внесении изменений в части первую, вторую и третью Гражданского кодекса Российской Федерации ", которым с 01 сентября 2018 года вводится новая форма юридического лица - Наследственный фонд. Возникает интерес, 
какие функции будет нести это новое образование, каковы его преимущества и недостатки?

Прежде чем обратиться к регулированию данного вопроса в отечественном праве, с одной стороны, необходимо учесть многовековую историю создания и существования частных фондов, как в Америке, так и в странах Европы, сходных по признакам правовой формы, но различных по целям и характеру деятельности.

За границей практика создания подобных фондов существует уже давно. Они создаются бизнесменами и очень богатыми людьми еще при жизни. Целью создания таких фондов за рубежом является не только поддержка после своей смерти родственников, но и возможность приносить пользу обществу, направляя средства фонда на благотворительность. Самым известным примером такой благотворительности может служить фонд Нобеля.

С другой стороны, не стоит отрицать неоднозначного отношения многих стран к созданию подобных частных фондов. Так, некоторые из них, например Франция и, что немаловажно, до недавнего времени и Россия, отрицательно относились к их созданию. В то время как другие, например, такие как Германия, Лихтенштейн, Нидерланды, напротив, допускают создания частных фондов, причём нет принципиальной разницы между способом создания такого фонда, наследственным, созданным по завещанию и иными фондами. Если допускается создание частных фондов, то нет причин для того, чтобы разрешить их создание по завещанию, но запретить при жизни или наоборот.

В странах континентально-европейского права частные фонды являются аналогом английского траста, который впервые появился еще в XI веке. Передача имущества бенефициарам через такой институт в средние века стала активно использоваться как альтернатива завещанию и средство против налога на наследство.

Если говорить с точки зрения корпоративного права, то фонд, в отличие от корпоративных организаций, не имеет членства. Бенефициары частного фонда, вообще говоря, юридически не имеют влияния на управление фондом, например не могут своим волеизъявлением сместить руководство фонда, пренебрегающее интересами бенефициаров.

Соответственно, работоспособность частных фондов зависит от наличия в данной юрисдикции достаточно высокой культуры управления активами. В противном случае юридическая конструкция фонда может стать источником злоупотреблений руководителей фонда по отношению к выгодоприобретателям. В публичных фондах надзор за руководящими органами ложиться на государственные органы, как правило, специально для этого созданными. Что же касается частных фондов, то эта задача ложится на судебную систему. Таким образом, эффективность управления частными фондами в основном зависит от независимости судебной системы и наличия богатой судебной практики в области фидуциарного управления активами, а также от предоставляемых данным правопорядком возможностей раскрытия в ходе судебного разбирательства всей информации о деятельности руководства фонда.

Что касается вещного права, то правовая конструкция частного фонда, подобно правовой конструкции английского частного траста, в некотором смысле расщепляет классическую триаду права собственности (владение, распоряжение, использование). Владение и распоряжение имуществом осуществляется фондом, а выгоды от использования имущества, по сути, принадлежат бенефициарам. В связи с этим возникает множество вопросов о природе, характере и объеме прав бенефициара на имущество фонда.

В англо-американской правовой системе выработали определенный подход по отношению к трастам. Суть его заключается в следующем: « Если у бенефициара есть определенный интерес к имуществу, подлежащий судебной защите, то на этот интерес можно обратить взыскание по иску кредитора бенефициара. Если интерес бенефициара 
имеет слишком отдаленный или умозрительный характер, то этот интерес не поддается экономической оценке, а потому на него нельзя обратить взыскание».

Что же касается российского законодательства, то фонд рассматривается как некоммерческая организация, которая ставит перед собой «благотворительные, культурные, образовательные или иные социальные, общественно полезные цели». Федеральным законом от 29.07.2017 № 259-Ф3 определяется понятие Наследственного фонда, условия, цели и задачи его возникновения и существования.

Согласно принятым поправкам Наследственным фондом признается фонд, создаваемый во исполнение завещания гражданина и на основе его имущества. Основная деятельность фонда направлена на управление полученным в порядке наследования имуществом этого гражданина бессрочно или в течение определенного срока. Неотъемлемой частью завещания, условия которого предусматривают создание наследственного фонда, являются решение завещателя об учреждении Наследственного фонда, разработка устава фонда, а также определение условий управления фондом. При принятии такого решения завещатель также определяет порядок, размер, способы и сроки образования имущества фонда, лиц, назначаемых в состав органов данного фонда и порядок определения таких лиц. Наследственный фонд подлежит созданию после смерти завещателя по заявлению, которое нотариус, ведущий наследственное дело, направляет в уполномоченный государственный орган. В этой бумаге нужно указать имя гражданина или компании, которые будут управлять фондом. Таким образом, всё наследуемое имущество сразу после смерти владельца аккумулируется в новом правовом институте. Из этих активов или из доходов от их управления можно будет производить выплаты тем лицам, которых владелец состояния указал в завещании. Получателями таких денег могут быть не только физические лица, но и целые компании - все зависит от воли самого наследодателя.

К заявлению прилагаются решения об учреждении фонда и утверждении устава фонда, составленные при жизни гражданина - завещателя. Устав наследственного фонда и условия управления им нельзя изменить, за исключением случая, когда выгодоприобретатель признается недостойным наследником (ст. 1117 ГК). Наследственный фонд призывается к наследованию по завещанию после его создания.

Таким образом, новый закон все полномочия по учреждению фонда после смерти гражданина, основываясь на завещании наследодателя, передает нотариусу. В связи с этим, недоработкой законодателя представляется тот факт, что от этих важных действий отстраняется исполнитель завещания. Согласно внесенным поправкам он может лишь обратиться в суд, если нотариус нарушил законодательство. Между тем, если завещатель назначил исполнителя завещания, то, видимо, ему он доверял больше, чем нотариусу.

Стоит обратить внимание на следующие основные аспекты новых положений о Наследственном фонде РФ. Среди них:1) расширение сферы наследования по завещанию; 2) учредителем выступает исключительно одно физическое лицо; 3) создание Наследственного фонда происходит только после смерти наследодателя; 4) Наследственный фонд РФ является юридическим лицом и обладает признаками этого субъекта права; 5) целевое использование имущества, переданного фонду.

В новеллах наследственного права распоряжение о создании Наследственного фонда рассматривается как неотъемлемая часть завещания. Вместе с тем, представляется, что распоряжение завещателя о создании Наследственного фонда является самостоятельным способом распоряжения имуществом на случай смерти. Обращая внимание на преимущества и недостатки создания Наследственного фонда, стоит отметить, что решение наследодателя о создании фонда предопределяет особенный порядок распределения наследственной массы и иную судьбу имущества, передаваемого фонду. В данном случае, волеизъявление наследодателя о создании фонда и передаче фонду наследственной массы может ограничивать реализацию прав наследников по закону, включая и право на обязательную долю. Наследники, даже и участвующие в 
последующей деятельности фонда, уже не становятся непосредственными обладателями права собственности на объекты наследственного имущества. Также подразумевается и ограниченное целевое использование имущества, переданного фонду, напротив прежнего, как правило, неограниченного обладания и распоряжения объектами наследования со стороны наследников. Таким образом, при возникновении нового субъекта права, каким является Наследственный фонд, вещные правоотношения наследования трансформируются в обязательственные правоотношения по участию в управлении Наследственным фондом или приобретению имущества от фонда.

Другим недостатком рассматриваемой нормы можно отметить доктринальный подход РФ, согласно которому в завещании могут содержаться распоряжения только одного гражданина. Совершение завещания двумя или более гражданами не допускается. Российское законодательство по- прежнему не предусматривает среди правовых средств договорного наследования такие распространённые в мире институты как совместное завещание или наследственный договор.

С другой стороны, уникальность новой формы юридического лица Наследственного фонда - состоит в его раздельном существовании от учредителя - уже умершего наследодателя. В таком учреждении отсутствует лицо, которое является собственником наследственного имущества, переданного фонду. Таким образом, Наследственный фонд, являясь искусственной конструкцией и порождением правопорядка высокой ступени развития, самостоятельно существует в обществе вне принадлежности и вне зависимости от воли определённого физического лица.

В поправках, внесенных в Гражданский кодекс РФ Федеральным законом от 29.07.2017 №259-Ф3, предполагается так же, что Наследственный фонд не обязан преследовать публичные общественно полезные цели, а может передавать свое имущество частным лицам (выгодоприобретателям) (п. 3 ст. 123.20-1). Таким образом, законодатели осуществили довольно радикальную реформу законодательства о юридических лицах, впервые введя в российское право частные фонды, т.е. создаваемые для интересов частных лиц.

Само по себе желание наследодателя учредить Наследственный фонд и тем самым облагодетельствовать конкретных частных лиц, как правило своих родственников, вопросов, конечно, не вызывает. Однако для эффективного функционирования частных фондов система правосудия должна обладать рядом характеристик. К ним относятся следующие: 1) наличие у участников гражданского оборота культуры фидуциарного управления активами; 2) наличие у судов квалификации и технических возможностей по справедливому разрешению споров между фидуциариями и их бенефициарами; 3) наличие в правопорядке разумных правил относительно возможности обращения взыскания к бенефициару на его бенефициарный интерес; 4) наличие у судов квалификации и технических возможностей по справедливому разрешению споров по поводу претензий кредиторов бенефициаров в отношении имущества, находящегося в управлении.

Если считать, что такие предпосылки имеются, т.е. что следует допустить создание в России частных фондов, то совершенно необъяснимым выглядит то решение, которое предложено в законопроекте: все новшества относительно частных выгодоприобретателей относятся исключительно к Наследственному фонду. Авторы проекта почему-то считают недопущение смешивания наследственных денег и денег живых людей важной политико-правовой задачей. Во всяком случае, они запрещают внесение дополнительного имущества в Наследственный фонд другими лицами (п. 1 ст. 123.20-1).

В связи с проблематичностью концепции частного фонда многие европейские правопорядки не допускают создания частных фондов. Имеются ли достаточные предпосылки для их введения в России - большой вопрос. 
При отсутствии упомянутых предпосылок частные фонды неизбежно станут неиссякаемым источником злоупотреблений как руководителей фондов против выгодоприобретателей, так и выгодоприобретателей фондов против своих кредиторов.

$* * *$

1. Гражданский кодекс Российской Федерации (часть третья) от 26.01. 2001 №146-Ф3 (ред. от. 28.03.2017)//Собрание законодательства РФ. - 2001. - №49. - Ст.4552.

2. Налоговый кодекс Российской Федерации от 5 августа 2000 г. №117-ФЗ. Часть вторая (ред. от 13.04.2016 г.) // Собрание законодательства РФ. -2000. -№32. -Ст.3340.

3. Федеральный закон от 29.07.2017 N 259-Ф3 О «внесении изменений в части первую, вторую и третью Гражданского кодекса РФ: Федеральный закон от 29.07.2017 N 259-Ф3// URL: http://www.pravo.gov.ru (дата обращения 03.09.2017)

4. Карташов М. А. Общество с ограниченной ответственностью. Историко - правовой аспект.// Санкт Петербург: Издательский дом СпбГУ. - 2012. -с. 41 - 43.

5. Цуканова Е.Ю., Скопенко О.Р. Основания и механизмы отстранения от наследства недостойных наследников//Теория и практика современной России: сборник научных трудов международной научно-практической конференции. - 2016. - с.99-102. 


\title{
РАЗДЕЛ Х. ФИЛОЛОГИЯ
}

\author{
Дрёмина С.Л., Семилетова А., Кошель Е.А. \\ Особенности эпистолярного дискурса Ф.С. Фицджеральда \\ (на материале писем к дочери) \\ Дальневосточный государственный аграрный университет \\ (Россия, Благовещенск)
}

doi: $10.18411 /$ sr-10-10-2017-19

idsp: 000001:sr-10-10-2017-19

Письма американского писателя Френсиса Скотта Фитцджеральда являются образцом эпистолярного жанра; они не уступают по совершенству языка его художественным произведениям и, подобно им, способны доставлять подлинное эстетическое удовольствие. Ф.С. Фитцджеральд переписывался сЭрнестом Хемингуэем и многими другими известными людьми, но особую известность получили его письма к дочери.В данной работе будут рассматриваться проблемы функционирования английского языка в сфере эпистолярного жанра, представленного в этих письмах.

Дискурс рассматривается как вид языковой (речевой) деятельности, в котором отражено все богатство реальной ситуации, т. е. в особенностях дискурса отражаются личности коммуникантов, их мотивы, социальные статусы.

При изучении эпистолярного дискурса были исследованы труды Ю.А. Бельчикова, А.И. Ефимова, О.Ю. Подъяпольской, Л.В. Щербы и других, что позволило сделать вывод, что разновидностей дискурса выделяется достаточно много, и все эти разновидности задаются широким набором параметров. В каждом отдельном дискурсе выделяются свои языковые отличительные черты и особая стилистика, тематика текстов, способ рассуждения и т.д. Например, можно говорить о политическом дискурсе, дискурсе телевизионных новостей и т.д.

Следует отметить, что часто дискурс употребляется и используется учеными как понятие, довольно близкое по смыслу к понятию «стиль». Эпистолярный стиль исследователи выделили уже давно, хотя некоторые ученые считают, что письма являются простым вариантом устной речи. Как Необходимо подчеркнуть, что переписка в целом подразделяется на формальную и неформальную. Формальным письмам (например, деловым или коммерческим) свойственен строгий стиль и жесткие правила оформления.

Что касается неформальной переписки, она лишена таких строгих рамок, но, чтобы сообщение могло считаться именно письмом, в нем должны соблюдаться несколько условий. Во-первых, каждое письмо должно быть адресовано конкретному лицу, лично (либо косвенно) знакомому адресанту. Во-вторых, должно быть известно место и время написания письма. В письме необходимо излагать только то, что известно, а не выдумку, с указанием источника информации. Также люди, состоящие в переписке, должны иметь общий фонд информации, и обсуждать в письмах понятные друг для друга темы.

Сопоставив вышеперечисленные характеристики письма, представляется возможным полагать, что переписка Ф.С. Фитцджеральда с дочерью представляет собой эпистолярный дискурс особого рода. Исходя из этого, мы можем отметить, что все его письма адресованы дочери, для большинства писем (не для всех) известна точная дата, известно место отправления (чаще всего Калифорния). Во всех письмах изложена реальная информация, а не фантазии, т.е. эти письма можно отнести к эпистолярному жанру. В данной работе были рассмотрены в основном письма 1940 года.

Письма Ф.С. Фитцджеральда к дочери относятся к неформальной переписке. Такая переписка характеризуется связями и отношениями эмоционально-психологического характера и, по сути, является своеобразной эмоциональной связью между корреспондентами. 
Следует отметить, что в письмах много игровых, шутливых моментов. В некоторых письмах тон явно несерьезный. Себя, например, он иногда называет «oldmeany»// «старый жадина».

Тем не менее, другие письма, наоборот, поднимают серьезные вопросы, например, будущее образование дочери писателя, круг ее чтения, ее отношения с другими людьми. В некоторых письмах Ф.С. Фитцджеральд дает дочери достаточно серьезные советы относительно отношения к людям, например, в одном из писем он советует ей не пренебрегать талантливыми людьми, даже если они не очень успешны в жизни.

Также стоит отметить, что из писем следует, что Ф.С. Фитцджеральда интересует мнение дочери о его работе. Например, в письмах он спрашивает ее, читала ли она его статьи или рассказы, опубликованные в журнале «Эсквайр», интересуется, понравились ли они ей, что она о них думает, рассказывает ей о своих новых работах.

Как нам известно, дочь Ф.С. Фитцджеральда уже в университете начала писать статьи, и писатель дает ей некоторые советы о том, как писать. Также он делится с ней своими планами на будущее, в том числе творческими, рассказывает, какие книги пишет. Очень часто Ф.С. Фитцджеральд дает дочери советы относительно тех книг, которые, с его точки зрения, ей обязательно нужно прочитать, при этом среди тех книг, которые он советует, «Братья Карамазовы» и «Преступление и наказание».

Важно отметить, что Ф.С.Фитцджеральд часто в письмах обсуждает с дочерью вопросы, связанные с творчеством: что важнее в искусстве - создавать новые формы или совершенствовать их, как правильно понимать поэзию, и можно ли вообще ее понять и т.д.

Исходя из проделанной работы, мы можем сделать вывод, что характерные особенности рассмотренных эпистолярных текстов, оригинальность композиционного построения писем, их доверительность и эмоциональная окрашенность подтверждает вывод о том, что переписка Ф.С. Фитцджеральда представляет собой эпистолярный дискурс, имеющий самостоятельное значение в жизни и творчестве этого известного писателя.

$$
* * *
$$

1. Бельчиков, Ю. А. Литературный язык / Ю. А. Бельчиков // Русский язык: энциклопедия / под ред. Ф. П. Филина. - М. : Сов.энцикл., 1979. -311 с.

2. Ефимов, А. И. Стилистика художественной речи / А. И. Ефимов. - М., 1997. -441 с.

3. Подъяпольская О.Ю. Коммуникативно-прагматические особенности эпистолярного дискурса // Слово, высказывание, текст в когнитивном, прагматическом и культурологическом аспектах: сб. ст. участников IV междунар. науч. конф. Т. 1. - Челябинск: ООО «Издательство Рекпол», 2008.

4. Щерба, Л. В. Современный русский литературный язык / Л. В. Щерба // Рус.яз. в шк. - 1939. - № 4. - С. 21.

5. To Frances Scott Fitzgerald Spring, 1940 // URL: http://www.fitzgerald.narod.ru

\section{Злобина И.С.,. Рублёва О.С \\ Основные вопросы классификации неологизмов}

Вятский государственньй университет

(Россия, Киров)

doi: $10.18411 / s r-10-10-2017-20$

idsp: 000001:sr-10-10-2017-20

\section{Аннотация}

В статье обсуждаются вопросы классификации неологизмов, приводятся классификации предложенные отечественными и зарубежными авторами. Итоги проведенного теоретического исследования представлены в виде сводной таблицы основных дифференцирующих признаков классификаций неологизмов.

Ключевые слова: неологизм, классификация неологизмов, дифференцирующее основание. 
Разработка классификации неологизмов - одна из важнейших задач лингвистики, вопросы систематизации типов неологизмов детально рассматриваются многими лингвистами $[1,3,4,5,11]$. Анализ классификации неологизмов позволяет, во-первых, осмыслить уже реализованные направления работы по их изучению, а во-вторых прогнозировать пути и возможности новых исследований неологизмов.

Одной из самых основных классификаций можно считать классификацию Заботкиной В. И., которая разделила их на собственно неологизмы (новизна формы слова объединяется с новизной содержания), трансноминации (новизна формы слова сочетается с его старым значением) и семантические инновации (слову придается новое значение, а форма уже присутствует в языке) [4].

Сходным образом, Н. В. Кленовая выделяет семантические инновации, разграничивая следующие категории: сужение, расширение и перенос значения, который разделяет на два типа - метонимический и метафорический [5]. Ю. А. Жлуктенко разделяет взгляды на классификацию неологизмов Н. В. Кленовой [3].

Е. А. Мисуно классифицирует неологизмы по способу их образования, выделяя неологизмы, образованные при помощи:

1) аффиксации;

2) словосложения;

3) аббревиации;

4) семантической деривации;

5) конверсии;

6) заимствования [8].

Вопрос словообразовательных неологизмов подробно изучила Т. И. Арбекова [1], добавив обособление значения (когда одно из значений стало самостоятельным) и разделив неологизмы, образованные при помощи конверсии на четыре типа, в зависимости от части речи, в которое преобразуется новое слово: вербализация, субстантивация, адъективация, адвербализация.

Т. В. Попова предприняла попытку построения более полной классификации, выделив три дифференцирующих основания:

1) вид языковой единицы: неолексемы, неофраземы и неосемемы;

2) степень новизны языковой единицы: абсолютные и относительные неологизмы; основываясь на работах Т. Н. Поповцевой [7] в этой области, автор делит относительные неологизмы на вернувшуюся лексику (возрождение старых слов со своими значениями), актуализированную лексику (возрождение старых слов с новыми значениями) и внутренние заимствования (термины, слова, взятые из диалектов и субкультур) [11].

3) вид обозначаемой реалии: старая, новая, актуализированная, уходящая и несуществующая реалия [10].

Е.В. Маринова предлагает две классификации по двум дифференцирующим признакам:

1) по характеру неологизма автор делит их на узуальные и окказиональные, подразделяя их на потенциальные и собственно окказионализмы.

2) по структурному признаку, выделяя три типа неологизмов: фонетически новые, семантически новые слова, а также неологизмы, сочетающие оба способа [7]. 
Н. 3. Котелова разделяет неологизмы по способу появления в языке на новообразования и вхождения [6].

Попытка построения полной классификаций сделана Луи Гилбертом [13]. Он выделил фонологические и морфологические (аббревиатуры, акронимы, усечения и слияния) неологизмы, а также заимствования, разделив заимствования на четыре группы: собственно заимствованные, варваризмы, ксенизмы и кальки.

Ю. А.Мурадян предлагает при разработке классификации неологизмов учитывать характер объекта номинации [9]. Автор обращает внимание на то, какие явления отображает слово, выделяя:

1) неологизмы, описывающие новые явления, среди которых автор выделяет классические и локальные,

2) новообразования, описывающие старые явления, подразделяя их на уточняющие и придающие выразительность.

Гальперин И.Р. обратился к цели создания нового слова, определив неологизмы как книжные (новые слова), разговорные (у старых слов новые значения) и окказионализмы. Первую группу слов он предлагает разделить на терминологические (явления в разных сферах, например, в науке) и стилистические (неологизмы, образованные путем конверсии и словосложения, иногда добавления значений) [2].

Розен Е.В. делит неологизмы по характеру продуктивности на сильные (слова популярные в речи, образуются морфологическим способом) и слабые (заимствования из родственных языков, похожи на обычные) [12].

Учитывая приведенные выше классификации, стоит признать, что на протяжении долгих лет лингвисты пытались как можно более детально раскрыть тему классификаций неологизмов. Некоторые классификации пересекаются друг с другом, так как ученые работали в одной области, но тем не менее, это и подчеркивает сложность той проблемы, которая стоит перед учеными. Язык в сегодняшнее время развивается как никогда раньше, технологии появляются с невероятной скоростью, в результате, требуются наименования еще большему количеству явлений.

Итоги проведенной работы можно, в частности, представить с помощью сводной таблицы основных критериев классификации неологизмов (см. Таблицу 1).

Таблииа 1.

Основные критерии классификаиии и типы неологизмов

\begin{tabular}{|c|c|c|}
\hline & Критерии классификации & Типы неологизмов \\
\hline 1 & Способ образования & $\begin{array}{c}\text { Неологизмы, образованные при помощи аффиксации, } \\
\text { словосложения, аббревиации, конверсии }\end{array}$ \\
\hline 2 & Вид языковой единицы & Неолексемы, неофраземы, неосемемы \\
\hline 3 & $\begin{array}{c}\text { Степень новизны языковой } \\
\text { единицы }\end{array}$ & Абсолютные и относительные \\
\hline 4 & Вид обозначаемой реалии & $\begin{array}{c}\text { Неологизмы, обозначающие новую, старую, } \\
\text { актуализированную, уходящую или несуществующую } \\
\text { реалию }\end{array}$ \\
\hline 5 & структурный признак & Фонетические, семантические, фонетически-семантические \\
\hline 6 & Способ появления & $\begin{array}{c}\text { Новообразования (словообразовательные, семантические) и } \\
\text { вхождения (внутренние и внешние заимствования) }\end{array}$ \\
\hline 7 & Условие создания & Анонимные, индивидуально-авторские \\
\hline 8 & Цель создания & $\begin{array}{c}\text { Книжные (терминологические, стилистические), } \\
\text { разговорные, окказионализмы }\end{array}$ \\
\hline 9 & Характер продуктивности & сильные, слабые \\
\hline 10 & Характер объекта номинации & Неологизмы (классические и локальные), новообразования \\
\hline
\end{tabular}


Дифференцирующие основания делают классификации более полными, четкими и более эффективными, но не универсальными. Ограниченность таких классификаций проявляется тогда, когда появляются принципиально новые типы слов с признаками, не включенными в классификацию. Классификационный тип неологизма может быть описан через некоторый набор признаков, в то же время попытки составить «полный список» признаков (параметров и т.п.) будут удачными только для определенного момента времени: такой список всегда остается открытым для введения новых признаков/параметров, которые становятся актуальными в соответствии развитием языка.

$$
* * *
$$

1. Арбекова Т. И. Лексикология английского языка (практический курс): учеб. пособие. М., 1977. 240 с.

2. Гальперин И. Р. Очерки по стилистике английского языка. М., 1958. 459 с.

3. Жлуктенко Ю.А. Английские неологизмы. Киев, 1983. 172 с.

4. Заботкина В.И. Новая лексика современного английского языка. М., 1989. 126 с.

5. Кленовая Н.В. Неологизмы в современной английской периодике: учебно-методическое пособие. Магнит-к, 2004. 32 с.

6. Котелова Н.3. Неологизмы. М., 1997. 255 с.

7. Маринова Е.В. Основные понятия и термины неологии. Челябинск, 2003. С. 243-247.

8. Мисуно Е. А. Перевод с английского языка на русский язык: учеб. пособие. Минск, 2009. 255 с.

9. Мурадян Ю.А. Типология инноваций в лексике английского языка. СПб., 1999. С. 122-126.

10. Попова Т.В. Неология и неография современного русского языка: учеб. пособие. М., 2011. 168 с.

11. Поповцева Т.Н. Относительные неологизмы. Л., 1990. С. 90-95.

12. Розен Е.В. Новые слова и устойчивые словосочетания в немецком языке. Л., 1991. 192 с.

13. L. Guilbert La Creativite Lexacale. Paris, 1975. 285 p. 


\section{JUURNAL_RU}

Научное издание

\section{Наука России: Цели и задачи}

Сборник научных трудов, по материалам

$\mathrm{V}$ международной научно-практической конференции

10 октября 2017 г.

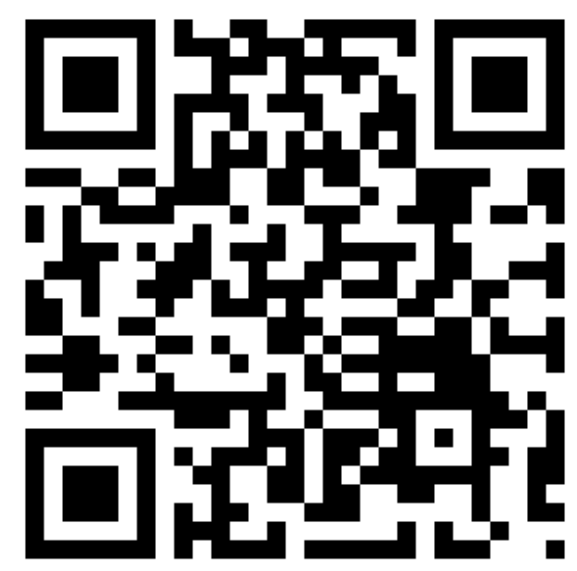

SPLN 001-000001-0190-SR

Подписано в печать 22.10.2017. Тираж 400 экз. Формат.60х841/16. Объем уч.-изд. л.4,37

Бумага офсетная. Печать оперативная.

Отпечатано в типографии НИЦ «Л-Журнал»

Главный редактор: Иванов Владислав Вячеславович 